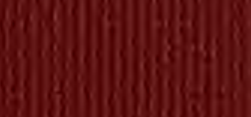




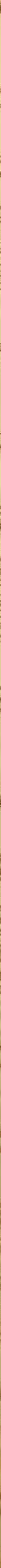







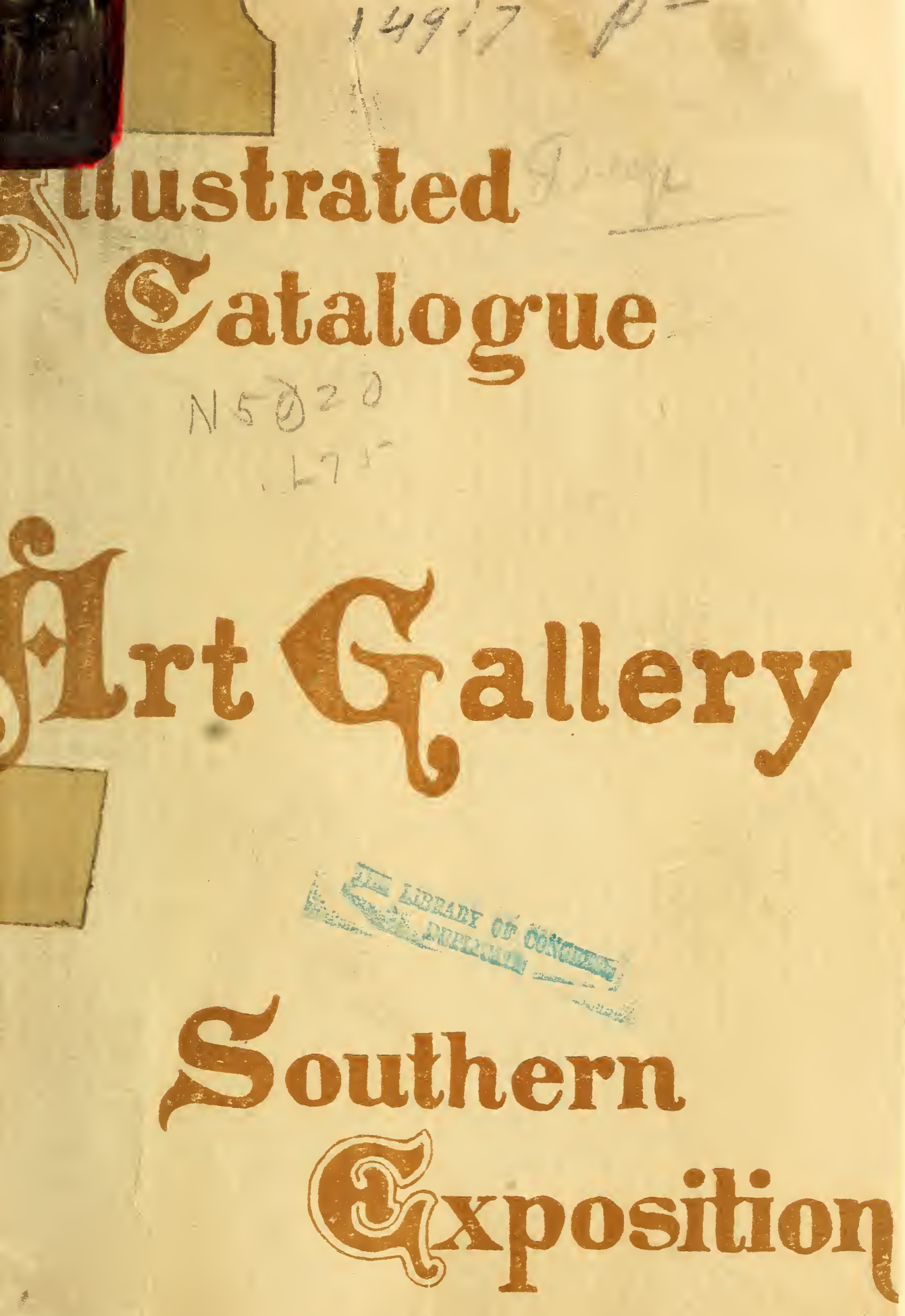




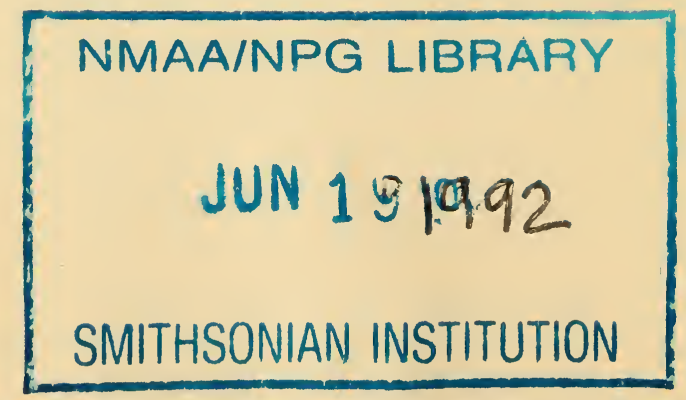


1884 LLUSTRATED CATALOGUE NMAA

\title{
ART GALLERY
}

OF THE

\section{Southern Exposition}

\author{
LOUISVILLE, KY.
}

August i6-October 25, I 884

Prepared by CHARLES M. KURTZ, DIRECTOR OF THE ART DEPARTMENT EDITOR OF NATIONAL ACADEMY NOTES AND OF THE ART UNION MAGAZINE.

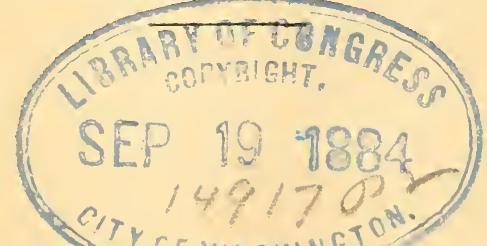

PUblished rok the SARt CoMmittee

By John P. Morton and Company. 


\section{SOUTHERN EXPOSITION.}

LOUISVILLE, KY., AUGUST I6-OCTOBER 25, I 884.

\section{EXECUTIVE OFFICERS}

BENNETT H. YOUNG, President.

J. H. LiNDENBERGER, First Vice-President.

N. BLoOM, Second Vice-President.

JOHN E. GREen, Third Vice-President.

J. W. STine, Fourth Vice-President.

CHAS. H. PETTET, Fifth Vice-President.

J. M. WRight, General Manager.

J. H. LINDENBERGER, Treasurer.

W. G. COldeWEy, Secretary.

\section{DIRECTORS}

CHAS. T. BALLARD. TEMPLE BODLEY.

ST. JOHN BOYLE.

T. E. C. BRINLY. JOHN MASON BROWN. J. J. HARBISON. JOHN B. CASTLEMAN. THOS. H. HAYS. M. LEWIS CLARKE. JOHN L. HELM. W. A. DAVIS.
H. P. FORWOOD. GEORGE GAULBERT. JOHN H. LEATHERS. CHAS. GOLDSMITH. EDW. W. M'KEIJNA. GEO. W. GRIFFITHS. W. H. M'KNIGHT. JESSE R. MIDDLETON. J. M. ROBINSON. JULIUS WINTER. J. M. WRIGHT.

\section{ART COMMITTEE}

Gen. JAmes A. EKIN, U.S.A., Chairman.

RT. REv. T. U. DUDLEY.

CAPT. ADDISON BARRETT, U.S.A. CARL C. BRENNER.

THOMAS ROYALL.
WILLIAM SEMPLE.

J. T. COOPER.

J. D. REED.

J. T. HOPKINS.

\section{WHAM PIRECTOR OF THE ART DEPARTMENT}

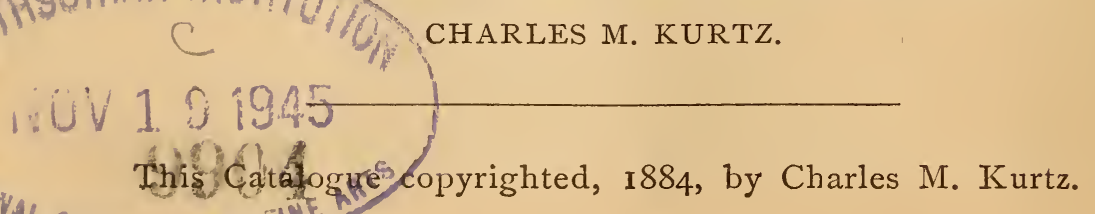




\section{INTRODUCTORY.}

The Art Committee hereby desires to express, publicly, its sincere thanks to the generous contributors whose names occur in due course in this Catalogue.

In the selection of paintings for the Art Gallery of the Southern Exposition this year, the Art Committee kept in mind that this was to be an American Exhibition, and that the most interesting collection of works of art, therefore, would be one representing the American artists at their best. Toward securing such a collection, representatives of the committee visited the studios of nearly all of the Eastern artists, and made personal selections from the pictures found therein. They also drew liberally from private collections and from some of the best known Art Dealers. About one third of the paintings were secured through an arrangement with the American Art Union, a society whose membership includes nearly all of the leading artists of this country.

A few paintings by representative foreign artists will be found in the collection, as well as some paintings of considerable antiquity. The latter are catalogued in all cases with deference to the attributions of their owners.

The sculptures exhibited are especially interesting to Kentuckians, in being for the most part examples of the work of a Kentuckian who attained world-wide recognition for most distinguished talent.

In the preparation of the Catalogue it has been the design to furnish such notes as might add to the visitor's interest, and give the book a permanent value for future reference. A number of illustrations have been added-mostly from drawings by the artists themselves, after their paintings-in the hope of giving the book a greater interest as a sou. venir after the Exposition closes.

Many of the biographical notices of the Artists have been prepared from personal interviews or through correspondence. Others have been obtained from Clement and Hutton's Artists of the Nineteenth Century, Tuckerman's Book of the Artists, Parke Godvin's Cyclopadia of Biography, the National Academy Notes, numerous American and foreign catalogues, and from various newspapers.

A large number of the illustrations herein contained have been taken, by permission, from National Academy Notes of different years; the others were prepared especially for this catalogue from drawings by the artists. 


\section{CONTENTS.}

SECTION I-Paintings.

Pictures in the Vestibule, . . . . . . . . . . . . 5-12

" " West Gallery, .......... I3-43

". " North Gallery, . . . . . . . . . . 44-68

" " East Gallery, . . . . . . . . . 69-9 I

\section{SECTION II-Sculptures.}

Sculptures in the Rotunda, . . . . . . . . . . . . . . 92-97

SECTION III-Illustrations.

Illustrations, . . . . . . . . . . . . . . i-x1

Index to Illustrations, . . . . . . . . . . . . . xli

"Artists represented,. . . . . . . . . . xlii

"Contributors, ............ xliv

\section{MEMORANDA.}

When prices are given, the pictures are for sale, and inquiries may be made at the desk by those desiring to purchase.

The prices in the Catalogue include payment for the frames.

No picture can be removed from the gallery before the close of the Exhibition.

Visitors are cautioned against touching the pictures or frames. All umbrellas and canes must be left in the vestibule; no charge is made for checking the same.

In the biographical notices of the artists are the following abbreviations:

B-born; D-died.

N. A.-National Academician (U. S.)

A. N. A.-Associate of the National Academy.

R. A.-Royal Academician (England).

A. R. A.-Associate of the Royal Academy.

Paintings designated by the * were obtained from the American Art Union, 5I West Tenth Street, New York. 


\section{Section I.}

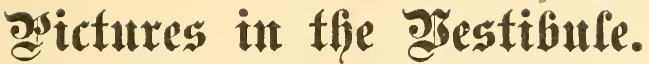

I. Napoleon Sarony, New York.

B. Quebec, I82I. His father was an officer in the Black Huzzars, and fought against the first Napoleon in the battle of Leipsic, subsequently, however, naming his son for the Emperor. Napoleon Sarony was brought to America when ten years of age, and when thirteen years old was thrown upon his own resources. He studied lithography first, and when twenty-one years old founded the house of Sarony, Major \& Knapp. This firm was very successful, and after acquiring a competency, as he supposed, Mr. Sarony went to Europe and spent six years there in observation and study. Losing his fortune, Mr. Sarony directed his attention to photography, and returned to America in I866. By studying his subjects with reference to appropriate surroundings, the most agreeable light and shade, and by highly artistic composition in his pictures, he almost revolutionized photography. Of late Mr. Sarony has devoted much of his leisure time to charcoal drawing. $\mathrm{He}$ is a member of the Tile Club and the Salmagundi Sketch Club, of New York. The following crayon drawings are by Mr. Sarony:

I. A Connoisseur. (Illustration, page xxxiv).

(\$200.)

2. The Bath.

3. A Vestal Virgin. (Illustration, page iii).

4. La Source.

5. Diego.

(Spanish, but no definite information at hand.)

Scene from Gulliver's Travels.

Joseph IV. Wayee, Cincinnati.

6. Harvey Joiner, Louisville, $\mathrm{Ky}$.

B. Indiana. Has had no art instruction; has been painting for about ten years.

Wild Flowers.

(\$200.) 
7. George Hetzel, Pittsburgh, Pa.

The most favorably known landscape painter in Western Pennsylvania. Some of Hetzel's forest interiors are equal-often superior-as far as truth to Nature goes, to the productions of landscape painters in the East who have much further extended reputation.

Woods in Pennsylvania.

$(\$ 500$.

8. August Carl, Louisville, $\mathrm{Ky}$.

B. Hochspeier, Bavaria, I856. Studied in Munich, under Piloty. Portrait of Col. E. C. Von Stamp.

9. A. Bryan Wall, Pittsburgh, Pa. Wash-board Falls, Pa.

Io. George C. Lambdin, N. A., Philadelphia, Pa.

B. Pittsburgh, Pa., I83o. Pupil of his father, a portrait painter. In I855 went to Europe and spent two years studying in Munich and Paris. First exhibited in the National Academy, New York, 1858. Elected member of the Academy, 1868. Member of the American Art Union. A great lover of flowers, he has turned his attention to painting them, and has achieved great success thereby. *Music and Refreshments.

$(\$ 250$.

11. Thomas Hicks, N. A., New York.

B. Pennsylvania, 1823. Devoted himself to art early in life, studying in the Pennsylvania Academy of Fine Arts, Philadelphia, and in the National Academy of Design, New York. I845-I849 in Europe, where he studied for a time with Thomas Couture, in Paris. Elected National Academician, 185I. He is one of the best-known and most popular of American portrait painters. Member of the American Art Union and President of the Artists' Fund Society of New York.

* A Neighborly Call.

$(\$ 600$.

I2. John Mulvany.

B. Ireland. Brought to America at an early age, and learned photography in Chicago. Had a gallery there and was burned out at the great fire. Then went to Europe and studied under Piloty.

The Comrade's Appea?.

Maj. W. H. Thomas, Louisville, Ky. 
13. Robert Hopkin, Detroit, Mich.

B. Glasgow, Scotland, 1831. Self-instructed.

Approach to Belfast Harbor, Coast of Ireland.

14. Frank F. English.

November at Atlantic City.

15. Philip Weber.

View of Heidelberg Castle.

I6. C. R. Leslie, R. A.

Harrison EArl, Philadelphia. (\$300.)

B. in England, I794; D. I859. Brought to America in I799, and after a short time at school, in Philadelphia, was apprenticed to a bookseller in New York. Returned to England I8I I, and entered the Royal Academy schools, studying also under Benjamin West and Washington Allston. Elected an Associate of the Royal Academy in I821 and Academician in I825. Returned to America to become Professor of Drawing at West Point in $183 \mathrm{I}$, but returned to England the following year. From 1848 to $185 \mathrm{I}$ was Professor of Painting at the Royal Academy. Author of a valuable "Handbook for Young Painters."

Garden Siene from "Romeo and Juliet."

"Peter and the nurse, with a message from Juliet to Romeo, whom they find in the garden with his friends."

I7. John Doyle.

Dr. J. R. Leaming, New York.

The famous caricaturist of London Punch.

Forest Interior, Autumn. DR. J. R. Leaming, New York.

I8. J. M. W. Turner, R. A.

B. London, I775 Son of a hair-dresser. Pupil of Thomas Girtin and the Royal Academy. Elected inember of the Royal Academy in r8or. Traveled all over England and Wales making studies, and visited Italy three times. Professor of Perspective in the Royal Academy in $\mathbf{1 8 0 7 . ~ M o s t ~ o f ~ T u r n e r ' s ~ b e s t ~ w o r k s ~ w e r e ~ b e - ~}$ queathed by him to the British nation, and are now in the Royal Academy in London. Good examples are much sought after, and bring almost fabulous prices. Probably his best pictures were painted between $\mathbf{I} 802$ and $\mathbf{1 8 3 2}$. His earlier works were elaborated almost to weakness, and his later pictures were extravagant in color and of fugitive media. D. $18_{5} \mathrm{I}$, in humble lodgings, where 
he was living under an assumed name in order that he might pursue his art without interruption. See Hamerton's "Life of $J . M$. W. Turner," and read Ruskin's and TAINE's criticisms of Turner's works.

Sketch-The Light Towers of the Herve.

rg. J. Jay Barber, Columbus, O.

Dr. J. R. Leaming, New York.

B. Ohio. First exhibited in the National Academy, I88I.

The Passing Shower.

$(\$ 400$.

20. Thomas Sully.

B. England, 1783. Brought to America, 1792. Studied art in Charleston, S. C., where he began to paint portraits. Lived in Richmond, Va., New York, and Philadelphia, finally settling in the latter city. Made several visits to Europe, and in 1838 painted from life a portrait of Queen Victoria for the St. George's Society, of Philadelphia. (See the Art Union for February, 1884.) Rather Windy (head).

Joseph E. Temple, Philadelphia.

(\$150.)

21. Ernest Parton, London.

B. Hudson, N. Y., 1845. Younger brother of Arthur Parton, in whose studio he spent two years. In 1873 went to Europe to spend a few months in Great Britain, but meeting with success in London, he resolved to remain there. Exhibits at the Royal Academy and Grosvenor Galleries.

Cattle at a Stream.

Dr. J. R. Leaming, New York.

22. James M. Hart, N. $\Lambda$., New York.

B. Kilmarnock, Scotland, I828. Brother of William Hart, N. A. $\mathrm{W}$ as brought to America when a child, his parents settling in Albany, N. Y. Here he worked with his brother in the shop of a coach-maker, decorating carriages. Displaying artistic talents of a superior order, he was encouraged to devote his attention to art study, and in $185 \mathrm{I}$ went to Düsseldorf, where he spent a year in the studio of Schirmer. He opened a studio in New York City in 1856, and was elected a member of the National Academy, 1859. In 1876 he was commended by the Judges at the Centennial Exposition.

In James M. Hart's studies of cattle, the same easiness is apparent which is so attractive in his more simplc landscapes, and when the two are united, the most delightful harmony is observed in every detail.-Art Jour nal, June, 1875 . 
Lost, Stolen, or Strayed.

(\$175.)

“James M. Hart's 'Lost, Stolen or Strayed' is one of the most pleasing of the many small pictures to be found in this exhibition. Two calves, coming down a shady path out of the dark woods, appear to be hopelessly lost, and the forward animal looks into the eyes of the spectator as if he would inquire the way. This picture, though small in size, shows Mr. Hart at his best. In it the cattle are as carefully studied as one finds them in Mr. Hart's larger, more costly paintings."

23. Percy Moran, New York.

B. Philadelphia, Pa., 1863. Pupil of his father, Edward Moran; of S. J. Ferris, of the Pennsylvania Academy of Fine Arts, Philadelphia, and the National Academy of Design, New York. Studied in France nearly three years.

An Interrupted Sitting.

(\$200.)

24. H. F. Farny, Cincinnati.

Favorably known both as painter and illustrator, in the latter capacity contributing to the leading magazines and illustrated journals.

Field Mice.

R. J. Menefee, Louisville.

25. E. J. Böks, The Hague, Holland.

A Demand in Marriage.

26. E. F. Andrews, Washington, D. C.

James S. Earle \& Sons, Philadelphia.

B. Ohio. Studied art for some years in Germany, and studied in Paris under Bonnat. Member of the American Art Union.

* Evening on the Avon, near Straiford.

$(\$ 300$.

27. Joseph R. Woodwell, Pittsburgh, Pa.

B. Pittsburgh, Pa., I842. Studied with George Hetzel, Pittsburgh, and afterward, in France, with E. Lambinet, I862-64. Studied in Rome in 1865 , and again in Paris in $1866-67$ and ' 68.

The Deserted Mill.

(\$400.)

28. E. K. Foote.

Turkish Fruit Seller.

F. T. M'FADDEN, Cincinnati.

29. William Hart, N. A., New York.

B. Paisley, Scotland, I822. Brought to America in I83I, to Albany, N. Y., where he became a painter in a coach-maker's establishment. More artistic talent than was required for that occupa- 
tion asserting itself, however, he became a portrait painter. Opened a studio in Albany, N. Y., in 1848 , but settled in New York, I853. Elected member of the National Academy, I858. One of the founders and for several years the President of the American Society of Painters in Water Colors; also President of the Brooklyn Academy of Design at its foundation in 1865 . Member of the American Art Union.

His pencil is alike chaste and living, true and tender, and many of his smaller landscapes are gems of quiet yet salient beauty.-TUCKERMAN, Book of the Artists.

William Hart's style is rich and glowing, and for subjects he prefers the brilliancy of a sunset sky, or the delineation of the gorgeous tints of autumn foliage, or nature in her brightest, rather than in her dark and gloomy phases. His paintings illustrative of sunset effects on the coast, for exquisite treatment of detail, unity of sentiment and fidelity, give a good idea of his poetic fancy.-Art Journal, August, 1875 .

Landscape and Cattle.

The American Art Association, New York. (\$80o.)

30. Albert Bierstadt, N. A., New York.

B. Düsseldorf, 1829. Brought to America at an early age. In I853 he returned to Duisseldorf and entered the Academy there; afterward he also studied in Rome, Switzerland, and Germany. Elected a member of the National Academy in I860, and later appointed Chevalier of the Legion of Honor, France. Member of the American Art Union. In $\mathbf{I} 867$ he was sent to Europe upon a Government commission, to make studies for a painting of the "Discovery of the North River by Hendrik Hudson."

Bierstadt's paintings have brought the highest prices of any American pictures. His Landor's Peak, Rocky Mountains, was bought by James McHenry for $\$ 25,000$; Estes Park, Colorado, bought by the Earl of Dunraven for $\$ 15,000$; and Storm in the Rocky Mountains, Mount Rosalie, bought by T. W. Kennard for $\$ 35,000$.

* Hunters' Camp in Winter.

(\$700.)

3r. William T. Richards, N. A., Philadelphia.

B. Philadelphia, 1833. Studied in Florence, Rome, and Paris. Honorary member of the New York National Academy, and member of the American Art Union.

No painter is more thoroughly a master of the sea and waves in motion than this artist.-Prof. WeIr, Report on Art at the Centennial.

His drawing is never at fault and the crispness of his touch is charming.Art Journal, August, 1877 .

* A Break in the Storm. 
32. J. William Pattison, New York.

B. Boston, Mass. After serving in the Army of the Potomac, studied art in New York. For five years was Professor of Art in Washington University, St. Louis. Went to Europe in I873, and studied with Albert Flamm, Düsseldorf, for three years; then went to France and studied for a time at Ecouen, becoming the pupil and friend of Luigi Chialiva. Returned to New York in the winter of 1883 . Member of the American Art Union.

* "Good Morning."

$(\$ 750$.

\section{PAINTINGS on the PILLARS of the ENTRANCE.}

33. Widgery Griswold, New York.

*Roses.

34. Lizzie F. Boyce, Louisville, Ky.

Pupil of Art Students' League and Mrs. Julia Dillon, New York.

Chrysanthemums.

35. Patty Thum, Louisville, Ky.

Pupil of Henry Van Ingen, at Vassar College, Poughkeepsie, N. Y. Rustic Beauties.

A bright, realistic study of some Hollyhocks.

36. Johannes A. Oertel, A. N. A., Washington, D. C.

B. Nuremberg, Germany, I823. Studied with Enzingmüller Munich. Came to America, I84S. Elected Associate of the $\mathrm{Na}$ tional Academy, 1856. Member of the American Art Union.

One of the most careful and painstaking of all our artists, and one of the very best draughtsmen in the country. Mr. Oertel devotes himself principally to subjects of Christian art, and some of his frescoes and cartoons are masterpieces both in conception and execution.

*Noonday Rest.

37. Otto H. Bacher, Cleveland, Ohio.

B. Cleveland, O., I856. Studied in Bavarian Royal Academy, Munich, I879, and Pupil of F. Duveneck, in Venice, ISSO-ISS2. First exhibited in the Society of American Artists' Exhibition of I881. In 1882 exhibited in Royal Academy, England. Member of the British Society of Painter-Etchers and American Art Union. Angelina-(A Venetian Girl). R. J. Menefee, Louisville. 
38. Charles A. Platt, New York.

Has studied art in America and abroad. Is at present studying in Paris. Is very favorably known for his etchings, which are among the best that have been produced in this country.

Shanties on the Harlem.

An etching which the artist made from this picture was one of his most successful and popular plates.

39. Percy Moran, New York. (See No. 23.)

The Young Fisherman.

(\$1OO.)

40. Unknown-After F. Vinea, Florence.

Cavalier Smoking.

MrS. J. M. REED, Louisville.

4I. J. E. Meadows, London.

Mt. Ephraim (near London).

DR. J. R. Leaming, New York.

42. Jennie Logan, Shelbyville, $\mathrm{Ky}$.

Hollyhocks.

(\$1 oo.)

43. Frank Waller, New York.

B. New York City, 1842. Was in business there until 1870, when he visited Rome and entered the studio of J. G. Chapman. In 1874, he became a member of the Art Students' League, of New York, at its foundation, and was its first President. Has traveled extensively in the East, and has made many studies in Egypt. Member of the American Art Union.

White Island Light, Isles of Shoals.

N. Sarony, New York.

44. R. Swain Gifford, N. A., New York.

B. on the Island of Naushon, Massachusetts, I840. Pupil of Albert Van Beest, Holland, and studied in Europe. Elected member of the National Academy, 1879. Member of the Society of American Artists, the American Water Color Society, New York Etching $\mathrm{Club}$, and British Society of Painter-Etchers. Awarded medal at Centennial Exposition, Philadelphia, 1876.

The Edge of the Desert.

(\$200.)

45. N. Sarony, New York. (See No. I.)

Summer. (Study in Crayon.) 


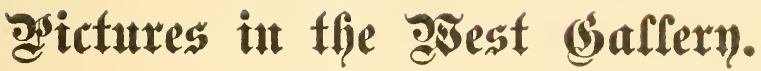

46. William Bradford, A. N. A., New York.

B. Fairhaven, Mass. For two years (at Fairhaven) with Van Beest of Holland. Has made seven voyages to the Arctic regions, spent four years in the practice of his profession in London, and seven years in California, in the Sierra Nevada Mountains. First exhibited, N. A. D., I864. Elected Associate of the National Academy, 1874. Member of the American Art Union.

With Dr. Hays, the Arctic explorer, and others, he has made several trips to the ice-regions of the North American coast for the purpose of sketching and study, chartering his own vessel, and going as high, on one occasion, as the fifty-sixth degree. His representations of this comparatively new field of icefloes and icebergs have been interesting and popular, and have attracted much attention on both sides of the Atlantic. Has exhibited publicly and privately in London, and has sold his pictures there to Her Majesty the Queen, the Marchioness of Lorne, the Baroness Burdett-Coutts, Baron Rothschild, and others. - Clement \& IIUtTon, Artists of the Nineteenth Century. * Morning off the Labrador Coast.

$(\$ 450$.

47. Thomas Moran, N. A., New York.

B. Bolton, Lancashire, England, 1837. Brought to America, I844. Displaying artistic taste at an early age, he was apprenticed to a wood-engraver in Philadelphia. Went to Europe in I862 and 1866, and copied many of the works of Turner in the National Gallery, London, and paintings of the old masters in Italy. In I87I accompanied the United States Exploring Expedition to the Yellowstone country. His "Grand Canon of the Yellowstone" and "Chasm of the Colorado" were purchased by the United States Government for $\$ 10,000$ each, and are now in the Capitol at Washington. Mr. Moran has also attained high position as an illustrator and etcher. Member of the National Academy, American Water Color Society, New York Etching Club, British Socicty of Painter-Etchers, and American Art Union.

\section{Landscape.}

Exceedingly rich in color, suggesting the work of one of the old inasters. 
48. Alice Barber, Philadelphia, Pa.

Studied in the Pennsylvania Academy of Fine Arts, under Thomas Eakins. Practised wood engraving for a time with great success, many of her blocks appearing in Scribner's Monthly and other publications. At present Miss Barber devotes considerable attention to illustrating. A Sandbank.

49. J. Portielje, Brussels.

\section{The Belle of Vienna.}

James S. EArle \& Sons, Philadelphia.

$(\$ 225$.

50. C. Bruger.

$A$ Winter Scene in Holland.

C. JANEntzki, Philadelphia.

5I. C. Giebel.

\section{The Crushing Moment.}

"Two apprentices in a shoe-shop have been playing cards; the master steps in and surprises them. One, greatly distressed, has attempted to conceal some of his cards under his apron. He raises one hand, as if to ward off an expected blow, and looks appealingly toward his companion, as if to ask him to 'stand by him.' The older boy, however, frowns as indignantly as the master, as if to show that he has had nothing to do with the cards. The face of the master is full of wrath, as, pointing to some cards remaining on the table, he confronts the boys with the evidence of their guilt. In technique this picture is as fine as any thing in the gallery. The expressions of the faces are admirably drawn, and the qualities of all the various elements are well realized. The picture is also pleasing in composition and color."

52. J. Portielje, Brussels.

JoseprI W. WAYNe, Cincinnati. $A$ Court Beauty.

53. C. Bruger.

James S. Earle \& Sons, Philadelphia.

In the Alps.

C. Janentzki, Philadelphia.

54. William T. Richards, Philadelphia. (See No.31.)

Tyntagel Castle.

Tyntagel Castle is on the coast of Cornwall, England. It was the birthplace of King Arthur.

Mr. Richards has never painted a more striking picture than his Tyntagel Castle. The tall cliffs rising from the sea, their sides hollowed out in to great caverns in which the storms play, and the grim old castle seeming as if it were a natural growth from the summit, are exceedingly impressive. The foreground, at the foot of the rocks, where great masses of stone have broken off and fallen is very realistic; and the water, stretching away into the fog, with a light streak along the horizon, is painted as few artists are able to represent water. The effect is that of early morning.

A. D. Vorce \& Co., Hartford, Conn. (\$2,500.) 
55. T. L. Smith, A. N. A., New York.

B. Glasgow, Scotland, I835. Came to America at an early age and studied with George H. Boughton, in Albany, N. Y. Went to New York City in 1862. Elected Associate of the National Academy, 1870. Member of the American Art Union. Has devoted himself almost exclusively to the painting of winter scenes.

Mr. Smith paints conscientiously, winter trees and snow, a farmer's cosy home, the calm, warm glow of a winter sky and clouds, truly and faithfully, according to his inspiration. His art, as far as style is concerned, is the art which conceals art, an individuality of thought and expression by which we recognize and sympathize with a fresh local inspiration from nature. $-N . Y$. Evening Post.

$A$ Winter Sunset. Grady \& M’Keever, New York. (\$Ioo.)

56. A. Bryan Wall, Pittsburgh, $\mathrm{Pa}$. Hoeing Cabbage.

57. Charles Warren Eaton, New York.

B. Albany, N. Y., I857. Studied at the National Academy and the Art Students' League, New York. First exhibited in the National Academy, I882.

$A$ Stone Mill on the Bronx.

(\$I 25.)

58. Sir Augustus Wall Callcott.

B. Kensington, England, I779. Pupil of Hoppner. At first practised portrait painting, but later devoted himself to landscapes. He has been called "the English Claude." The Queen conferred Knighthood upon him in 1837 , and in 1844 he was appointed Conservor of the Royal Pictures. D., I 844.

Abbottsford. DR. J. R. Leaming, New York.

59. George Hetzel, Pittsburgh, Pa. (See No. 7.)

* View on Duck Brook, Mt. Desert, Me.

$(\$ 400$.

"One of Mr. Hetzel's most charming forest interiors."

6o. Joseph R. Woodwell, Pittsburgh. (See No. 27.)

The Coast of Rhode Island.

6I. H. Bisbing.

The Road to the Farm.

62. W. T. Trego, Philadelphia, Pa.

B. Yardleyville, Pa., I858. Studied at Pennsylvania Academy of Fine Arts, Philadelphia. Received Charles Toppan Prize in ISS2 
and was awarded the Temple Silver Medal in 1883 at the Pennsyl. vania Academy.

U. S. Cavalrymen.

63. Alice Barber, Philadelphia. (See No. 48.) An Old Garden.

64. Madame G. M. De l'Aubiniére.

Through the Brush. (Water Color.)

M. SARony, New York.

65. F. K. M. Rehn, New York.

B. Philadelphia, Pa. Pupil of Pennsylvania Academy of Fine Arts. First exhibited National Academy, I879. Was awarded first prize for a marine painting at the St. Louis Exposition, I882. Near Bass Rock, Cape Ann, Mass.

J. T. Cooper, Louisville.

66. Morston Ream, New York.

B. I840. Has applied himself closely to painting fruit for many years. Exhibits in nearly all of the principal exhibitions.

$A$ Basket of Fruit.

67. William M'Leod, after Charles Louis Muller.

Charlotte Corday in Prison.

Original in the Corcoran Art Gallery, Washington, D. C. (Illustra. tion, page $\mathrm{xxx}$.)

$(\$ 400$.

William M'LEOD, Curator of the Corcoran gallery, studied art in his earlier years and attained considerable proficiency in it. Since he has had charge of the Corcoran gallery, he has made copies of several of the most important pictures, some of which are so like the originals as to deceive connoisscurs. The 'Charlotte Corday', here shown, is exactly the size of the original. Since it was painted, a rule has been established that no copy larger than two thirds of the size of any original picture in the gallery shall be made.

Charles Louis Muller, painter of the original picture, was born in Paris in 1815. Pupil of Gros and Cogniet. Member of the Institute of France, and officer of the Legion of Honor. The recipient of numerous medals. Of Muller, JARves, in his Art Thoughts, says: "Muller attempts nothing that he can not do thoroughly well, and in a quiet, truth-telling manner. His system gives all to art, regardless of exhibiting the artist. ... Muller paints history as Motley writes it, picturesquely, and with insight into its emotions."

The following, concerning this picture, is taken from the admirable catalogue of the Corcoran gallery-prepared by Mr. M'Leod:

Charlotte Corday, descended from a noble family, though a republican, determined to rid the republic of the blood-thirsty Marat, who sent to the guillotine all opposed to him. She managed to obtain an audience with the monster while he was in his bath, and as he was in the act of taking the names 
of some of her countrymen as fresh victims, she stabbed him to the heart. After a trial she was guillotined on the 7 th of July, I793, aged twenty-five years. She never repented the deed, and displayed firmness and composure to the last.

The artist has depicted her in the garb of a rustic, with tricolor ribbons on her cap, resting languidly upon the rusty iron bars of her prison window. Her right arm is braced against the stone wall, the hand holding a pen, supporting the drooping head. The left hand clasps the iron bars-a touching contrast between its delicate, slender fingers and the rusty metal. The pose of the form shows weariness, as does also the pale face looking through the grating with thrilling, earnest mournfulness. She appears as if, weary with writing the noble letter below, to her father, she had sought the window for air untainted by prison walls. Her mouth shows unfaltering firmness, and her eyes show watchfulness and sadness-but not the sorrow of personal affliction. There is in them no sign of remorse nor of regret, unless over the necessity of her terrible act.

"Pardon me, my dear father, for having disposed of my life without your permission. I have avenged many victims-prevented others. The people will one day acknowledge the service I have rendered my country. For your sake I wished to remain incognito; but it was impossible. I only trust you will not be injured by what I have done. Farewell, my beloved father! Forget me, or rather rejoice at my fate, for it has sprung from a noble cause. Embrace my sister for me, whom I love with all my heart. Never forget the words of my heart. Never forget the words of Corneille-the crime makes the shame, and not the scaffold."

The picture is free from the tragic treatment the subject is too apt to receive from French artists. Its color throughout is grave and subdued. The clear, pale face, the plain gray garb, the stone wall and rusty bars, are all in solemn keeping. Even the rosy tips of the exquisitely moulded fingers harmonize with the prevailing gravity of color.

68. Theodore Weber, Paris.

Pupil of Andreas Achenbach and Munthe.

Off Boulogne, French Coast.

A. D. Vorce, Hartford, Conn.

$(\$ 300$.

69. E. Gesselschap, Düsseldorf. Forbidden Fruit.

N. A. Frankel, Louisville.

7o. R. V. Brooke, Washington, D. C.

A Young Italian.

7 I. Carl C. Brenner, Louisville, Ky.

B. Lauterecken, Rheinpfalz, Bavaria, 1838. Pupil of Prof. Philip Frœlig. Came to America, I854-to Louisville. Nember of the American Art Union.

Through the Clearing. George H. Moore, Louisville. (Illustration, page $\mathrm{x}$. ) 
72. Benoni Irwin, A. N. A., New York.

Studied in the National Academy of Design, I863-1865; afterward with Carolus Duran, Paris, I877-1878.

* Lobster Boiling at New Bedford, Mass.

(\$500.)

73. Langheimer.

The Gossips.

Mrs. P. WoOldridge, Louisville.

74. Thomas Gainsborough.

B. at Sudbury, in Suffolk, England. Pupil of Francis Hayman. Became very eminent as a portrait painter, and his landscapes are held in high esteem.

Landscape.

Dr. J. R. Leaming, New York.

75. Sophie Gray, Louisville.

Pansies. (Water Color.)

76. H. Bisbing.

The Shore of the Zuyder Zee, Holland.

Harrison EArL, Philadelphia. (\$IOO.)

77. Sophie Gray, Louisville.

Trumpet Flowers.

78. Max Weyl, Washington, D. C.

Member of the American Art Union.

* Near Atlantic City, N.J.

A landscape most excellent in qualities.

79. Benoni Irwin, A. N. A., New York. (See No. 72.)

Portrait of Mr. Albert Fink.

One of the best portraits that has been produced in this country.-Louisville Courier-Journal.

8०. G. P. A. Healy, N. A., Chicago.

Albert Fink, New York.

B. Boston, 1808. Has lived in Europe for the greater part of the time since 1836 , practising his art in Paris and Rome. Received a third-class medal at the Paris Salon of 1840 , and a second-class medal in 1855 . Has painted portraits of many of the most distinguished citizens of this country. Honorary member of the $\mathrm{Na}$ tional Academy, New York.

Portrait of the Artist.

Mrs. C. S. Adams, Louisville. 
8r. Mattie W. Kirby, Louisville, Ky.

A Musical Study.

(\$IOO.)

The music, a high mass, was taken from a folio from an old monastery in Europe.

82. Martin J. Heade, New York.

B. Bucks County, Pa. Began professional career as a portrait painter. Spent two years in study in Italy. Went to Brazil with the intention of procuring material for a work on the hummingbirds of South America, which, however, was not published on account of difficulty with reproductive processes for color illustrations. While in Brazil, Mr. Heade received from the Emperor the decoration of "Chevalier of the Order of the Rose."

No one of our artists has a more refined sense of beauty or a more delicate feeling for color.-Tuckerman, Book of the Artists.

Harvesting on Long Island.

James S. EArl \& Sons, Philadelphia.

(\$200.)

83. M. H. F. De Haas, N. A., New York.

B. Rotterdam, Holland, I832. Pupil of Academy of Fine Arts, Rotterdam, and Louis Meyer, at the Hague. In 1857 appointed artist to the Dutch Navy. Came to New York, i859. Elected member of the National Academy, I867. Member of the American Water Color Society and the American Art Union.

His manner of handling is broad and vigorous. His pencil is equally facile, whether portraying a storm on the coast, a moonlight effect at sea, or the brilliancy of the sunset hour.-Art Journal.

*A Fresh Breeze, Massachusetts Bay.

(Illustration, page xi.)

$(\$ 2,500$.

(From this year's National Academy Exhibition). . . . Fishing smack coming toward the spectator. Sky full of moving clouds with patches of blue showing through. The sea, the sky, and the distended sails would impress upon one the significance of the title were no title given.-National Academy Notes, 1884 .

Considered one of the finest paintings that has come from the brush of this acknowledged master.

84. William Hart, N. A., New York. (See No. 29.)

* Near Kingston, Ulster Co., N. Y.

$(\$ 425$.

85. Charles Taylor, R. A.

B. England. Member of the Royal Academy and of the Society of Painters in Water Colors.

Off the English Coast. (Water Color.)

William Henry Davis, Cincinnati. 
86. Léon Moran, New York.

B. Philadelphia, Pa., I863. Pupil of the National Academy of Design, New York. Studied for one year in France.

Sundown. (W'Tater Color.) N. SARony, New York. (\$250.)

Painted with great care and delicacy; one of the finest water colors $\mathrm{Mr}$. Moran has produced.

87. William L. Sonntag, N. A., New York.

B. Pennsylvania, I822. Self taught. Has been abroad and has studied in Italy. Part of his professional life was spent in Cincinnati, but he has lived in New York for the past thirty years. Elected member of the National Academy, I861. Member of the American Water-Color Society and the American Art Union.

* An Old Mill-dam.

88. J. E. Kelley, New York.

Well known by his illustrations.

Morning After a Battle. (Black and White.)

N. SARony, New York. (\$1Oo.)

89. Benoni Irwin, New York. (See No. 72.)

$A$ Veiled Lady.

The ARTist.

9o. Charles Brenner, Louisville, Ky.

B. Louisville. Pupil of his father.

After the Smoke.

An exceedingly careful, realistic study of still life well suggesting its title.

9r. H. Bisbing.

$A$ Calf Pasture in Holland.

IAARrison EARI, Philadelphia.

(\$150.)

92. E. Wood Perry, N. A., New York.

B. Boston, 1831. For some time in a mercantile house in New Orleans. In 1852 began the study of art. Studied for a time in London and Paris, and then went to Düsseldorf, and spent two years and a half in the studio of Leutze. Afterward a pupil of Thomas Couture for a year, in Paris. I857 to I860, United States Consul in Venice. Upon his return to the United States, he painted portraits in the principal cities of the South and West, and then went to California and the Sandwich Islands. Settled in New York in 1866. First exhibited, National Academy, 1859. 
Elected member of the Academy, 1869. Secretary of the American Art Union.

Perry, at the present time, occupies a place very nearly at the head of our American genre painters. He was one of the first to paint American subjects, and the most lowly of them are invested with a poetry of fecling and delicacy of expression which are not exceeded by any of his contemporaries. His pictures are illustrative and pleasing, and evince a conscientious study of his subjects.-Prof. Weir.

* Young Franklin at the Press.

93. A. Bryan Wall, Pittsburgh, Pa. $A$ Sketch from Nature.

94. Annie W. Jones, Chicago. Making the $W^{\prime}$ edding Dress.

95. George F. Fuller, New York.

B. Boston, Mass. Began painting in Boston in 1843 , then lived successively in New York, Louisville, New Orleans, Paris, and London, finally returning to New York, where he now resides. For a time a pupil of Durivage. Mr. Fuller is as well known for his literary as for his artistic achievements. His letters to the Louisville Courier-Journal, over the signature "Mahlstick," have given him wide reputation.

* View on Rock Creek, near Washington, D. C.

(\$100.)

96. Theodore Frère, Paris.

B. Paris, I8I5. Brother of Edouard Frère and pupil of Cogniet and Roqueplan. He first exhibited in the Salon in 1834. Two years later he went to Algiers, and much of his life has been spent in the East, as much of his work having been accomplished in his studio in Cairo as in his studio in Paris.

The Caravan. Morston Ream, New York. (\$I $\quad$ Mo.)

97. A. Roosenboom, Brussels.

Rather Sulky. Joseph E. Temple, Philadelphia. (\$I25.)

98. W. T. Trego, Philadelphia. (See No. 62.)

The Bugle-Call.

99. Peter Moran, Philadelphia.

B. Bolton, Lancashire, England, I842. Was brought to America when a child, and studied art with his brother, Thomas Moran, in Philadelphia. In 1863 went to London and studied the manner of 
the English masters for a time. Member of the Pennsylvania Academy of Fine Arts and the American Art Union. Received a medal for his painting at the Centennial Exposition. Has achieved high reputation as an etcher.

* A Laborer, Taos Valley, Mexico.

(\$IOO.)

I0o. Samuel Colman, N. A., New York.

B. Portland, Me., I833. Practised drawing from his early youth. In 1860 went to Europe and spent two years in study in Paris and Spain. In I87 I again went abroad - to Paris and Rome. Elected National Academician, 1862. In 1874 lived in Dresden. Returned to New York, I876. One of the original members of the Society of American Artists, I878. One of the founders of the American Society of Painters in Water Colors, and its first President, I866-I87 I.

There is nothing monotonous about Mr. Colman's style; his work is always pleasing, and will be ever welcome in our exhibitions.-Art Journal, September, 1876 .

The White Mountains.

Dr. J. R. Leaming, New York.

Ior. Samuel Colman, N. A., New York. (See No. Ioo.)

The Conway Meadows. Dr. J. R. Leaming, New York.

102. Xanthus Smith, Philadelphia, Pa.

The Opening of the Battle of Gettysburg.

James S. EArle \& Son, Philadelphia.

(\$250.)

I03. William Morgan, A. N. A., New York.

B. London, 1826. First studied in the Government Art School at Havre, France; afterward came to America and became pupil of the National Academy and of Vincent Colyer, New York. First exhibited in the National Academy, 1851. Elected Associate Member of the Academy, 1865. Member of the American Art Union.

Mr. Morgan's pictures are always pervaded by a deep sympathetic quality that shows how much the heart of the artist is in his work. They are not mere photographic presentations of facts before our eyes, but without in any manner sacrificing truthfulness, they give us facts influenced by transmission through an intensely poetic nature.

*The Sortic.

(Illustration, page xix).

A crowd of school-boys are being marshaled in battle array. Only the commander and musicians are shown in the illustration. The painting contains many figures armed with brooms, rakes, and various other extemporized weapons. A little girl waves a handkerchief to them from an open window. Bright in color; vigorous in action.-National Academy Notes, 1884. 
I04. Walter Blackman, Paris.

B. Chicago, Ill., 1846. Pupil of TEcole des Beaux Arts and of J. L. Gérome, Paris. Exhibits yearly in the Salon and in various New York exhibitions. He is peculiarly successful in the rendition of flesh, and the color effects in his paintings are usually very fine. His works are already in good demand, and their popularity is extending. A Beauty of the Olden Time.

(\$650.)

105. Olim Frazer.

American Art Association, New York.

B. Kentucky. Pupil of Matthew H. Jouett, and afterward studied in Europe, visiting the principal galleries in England, Brussels, and France, studying the works of various masters. D. Lexington, $\mathrm{Ky}$. The Artist's Family. (Painted in I848.)

Miss Bessy Frazer, Lexington, Ky.

106. Robert Burns Wilson, Frankfort, Ky.

Has had no art instruction, but has painted some pictures which have attracted attention. Is better known as a writer of short poems than as an artist. Some of his verses are exceptionally fine and have been widely quoted.

A Kentucky Landscape.

The ARtist.

I07. Thomas Moran, N. A., New York. (See No. 47.) * Storm on the Coast, Easthampton.

(For sale.)

A wonderfully realistic presentation of dashing, tempestuous waves.

\section{I08. Jan Steen.}

B. 1626, at Leyden; called "the jolly landlord of Leyden." Studied first with Nicolas Knupfer and later with Jan Van Goyen, whose daughter he married. He was especially fond of the ludicrous, and family feasts and merry-makings, the weddings of illassorted couples, tavern brawls and similar scenes, were among his favorite subjects.

Prof. Anton Springer, of Leipsic, characterizes Jan Steen as the foremost colorist of the entire Dutch school. He also says; "A spontaneous joyousness pervades his works, and a sparkling sense of humor, too. His pictures might be entitled comedies of life, in which man's follies are chastised with satire, and his weaknesses held up to ridicule, but without the glaring exaggeration and obtrusive moralizing which make the pictures of Hogarth (with whom Jan Steen has much in common) so unpleasant to look upon. Jan Steen has, with justice, been likened to Moliere."-A Historical Sketch of Art in the Netherlands.

The Peddler.

Dr. J. R. Leaming, New Tork.

One of the finest examples of Jan Steen's characteristic manner to be found. In color ranking among his very best works. 


\section{rog. A. H. Wyant, N. A., New York.}

B. Ohio, 1839. Pupil of Hans Gude, and studied in Düsseldorf and London. First exhibited in the National Academy, 1865. Elected Academician, 1869. Member of the American Art Union, Society of American Artists, and American Water-Color Society.

In landscape art the American artists are leading the wor'd to-day. Who is there now living who can excel George Inness when Inness is at his best? And who, better than Wyant, can lead man's thoughts away from himself and the petty affairs of his world, into a contemplation of the mystery and beauty and wonderfulness of God's world? The pictures of Inness and Wyant, in technique differing as they do, in the same manner show the spectator how much there is in Nature that he has seen without perceiving, and create in him a fuller desire to study the sublime teachings of Nature for himself. Their pictures, like those of Corot, are full of the spirit and the poetry of Nature. But while Corot only gives us an impression of the spirit of a scene, they give us the realization of the scene itself along with all of its spirit. And they do this without sacrificing the poetry that Corot saw in Nature.-Louisville Spectator, I883.

As a painter of the wild and rugged scenery of the Northern wilderness of New York, Wyant has few equals in the Academic ranks.-Art Journal, December, 1876 .

A Pool in the Adirondacks.

An exquisite effect of a foggy morning with a light breaking through the clouds. One of Mr. Wyant's most charming pictures.

Major C. J. F. Allen, Louisville.

\section{Io. Vergilio Tojetti, New York.}

B. Rome, Italy, I849. Studied first with his father (a well-known artist, now living in San Francisco, Cal.), and later with J. Leon Gerome and W. A. Bouguereau, in Paris. First exhibited in the Salon, Paris, in 1879, and in the National Academy, New York, two years later, when his Richelieu and Julie was shown. Mr. Tojetti has recently completed two ceiling-paintings, for the Hoffman House, New York, that are among the finest works of the kind to be seen in the country. He has also produced some of the finest decorations in the Vanderbilt houses in New York:

Sketch for "The Veiled Prophet of Khorassan."

(Illustration, page iv.)

This painting illustrates a scene from Lalla Rookh, where the Veiled Prophet of Khorassan surprises Azim and Zelica.

Azim has endeavored to persuade Zelica to fly with him. She refuses, however, to join her blighted life with his; whereupon he assures her that she is still pure to him, and that by prayer she may purified in the sight of heaven. Then Zelica:

"And thou wilt pray for me- ...

And plead for me with heaven, till I can dare 
To fix my own weak, sinful glances there;

Till the good angels, when they see me cling

Forever near thee, pale and sorrowing,

Shall for thy sake pronounce my soul forgiven,

And bid thee take thy weeping slave to heaven!

O yes, I'll fly with thee!"-

Scarce had she said

Those breathless words, when a voice deep and dread

As that of Monker waking up the dead

From their first sleep-so startling 'twas to both-

Rung through the casement near: "Thy oath! thy oath!"

Moore's Lalla Rookh.

The illustration given on page iv was made from the finished picture, for which the picture here was the preliminary sketch. There are some differences which will be noticed. The pose of Zelica is almost entirely changed. However, there are enough points of similarity in the picture and illustration to make the latter come in place in this book.

II I. William H. Beard, N. A., New York.

B. Painesville, O. Studied from Nature. Began his career as a portrait painter, settling in Buffalo, N. Y., in I850. In 1857 went to Europe, where he studied and painted in Düsseldorf, Rome, and Switzerland. Came to New York, 1860. Elected N. A., IS62. Member of the American Art Union.

He paints animals from the humorous point of action, passion, and sentiment. With him humor is a fine art. He has an exquisite sense of the ludicrous and sensuous. His brutes are four-legged humanity. In his own vein he has no equal.-JARves.

\section{* Landscape with Deer.}

(For sale.)

This is in Mr. Beard's more serious vein. It is a conscientious study of a forest interior with deer drinking at a stream in the foreground. There is a fine effect of light coming through the trees.

II2. Frederick J. Waugh, Paris.

Secrets of an Old Cabinet.

James S. Earle \& Sons, Philadelphia.

\section{3. Arthur Quartley, A. N. A., New York.}

B. Paris, I839. Entirely self-taught. His professional life has been spent in Baltimore and New York. First exhibited at the National Academy, I875. Elected Associate of the Academy, I879.

Now in London.

In the front rank of our marine painters.-Art Journal.

\section{Low Tide.}

"One of the most exquisitely beautiful pictures Mr. Quartley has painted. The smooth water left in the depressions along the shore, the hazy distance, the luminous sky, and the boat and figures in the middle distance are must charmingly rendered, and are all in perfect harmony in color." 
I I. Jennie Brownscombe, Honesdale, $\mathrm{Pa}$.

B. Honesdale, Pa. Pupil of Prof. L. E. Wilmarth, N. A., and the National Academy of Design, New York. Received first prizes in the Antique and Life schools of the National Academy. First exhibited, in the National Academy, in 1876. Studied abroad I882-83, mostly with Henry Mosler, Paris.

The Last Look.

(Illustration, page $\mathrm{x} x$ viii.)

A young girl in the costume of the early part of the present century, giving the finishing touches to her toilet. The interior painted from a picturesque nook in the Musee de Cluny, Paris. Rich tapestry background for figure,National Academy Notes, 1884 .

\section{II5. John James Audubon.}

B. 1782. Went to Paris in 1795 and studied art under David. In I798 settled on a farm in Pennsylvania until 1810, when he sailed down the Ohio River to sketch the birds of the country. In I8I I went to Florida for the same purpose, and later made many such journeys through various parts of the country. In 1826 went to Europe and began the publication of his "Birds of America"completed in 1839 in 87 parts, containing 448 plates, life-sized and colored, from his own drawings. His "Ornithological Biography" was published in 1839. Many of Audubon's original drawings are in possession of the New York Historical Society. D. 1851 .

Mud Szerallows.

Miss H. B. Audubon, Louisville.

II6. Burr H. Nicholls, New York.

Studied abroad for a number of years. Returned about a year ago.

A Venetian Courtship.

(\$600.)

II7. George C. Lambdin, N. A., Philadelphia. (See No. Io.) *Pink and Yellowe Roses.

II8. George H. Story, A. N. A., New York.

B. New Haven, Conn., 1835. Began his studies at age of fifteen under Prof. Bail, of New Haven, and later spent two years in the studio of Charles Hine, a portrait painter of the same city. Spent a year in studying the works of the old masters in Europe, and then resided two years in Portland, Me., where he was given a medal by the State, in $\mathbf{1} 848$, for oil painting. Spent two years in 
Washington, D. C., in portrait painting, and one year in Cuba. Finally settled in New York, and was elected Associated member of the National Academy, in 1875. Member of the American Art Union.

$\mathrm{He}$ invests his works with so much refinement of feeling that they at once arrest attention in whatever position they may be placed.-Art Journal.

* The Broken Vase.

$(\$ 500$.

(Illustration, page xxiv.)

Irg. Francesco Solimena.

B. Nocera de Pagani, Italy, I657. He was a very successful artist and left a fortune of 200,000 scudi and numerous pictures. He was a friend of Giordano. There are numerous works by him at $\mathrm{Na}$ ples, and several in the Dresden Gallery. D. 1747.

The Victory of St. Michael. $\quad$ R. J. Menefee, Louisville.

St. Michael, whose name signifies "like unto God," is regarded as the highest and mightiest of all created spirits. He it was whom God commissioned to expel Satan and the rebellious angels from heaven. His office now is believed to be two-fold-including that of patron saint of the church on earth, and Lord of the souls of the dead, deciding their merits, presenting the good to God and sending the evil and wicked away to torment.-Clement's HIandbook of Legendary Art.

Of this picture the following was published in The Age, April 5, x879: . . "The authenticity of the work is beyond question. Its present owner bought it in 187 I from a member of the family in whose house in Naples it had hung from the days of the great painter. It was the original study for a celebrated fresco by the artist, and remains crude and unfinished in some of the outer parts. The state of the canvas-on which, however, the work itself remained intact-made it necessary to have the work put on, or backed by, new canvas, which was done by Pinti, the celebrated London restorer. The torn edges were carefully put together, and to-day the picture is in a perfect state of preservation, fresh and glowing. In size it is thirty-four by twenty-four inches. St. Michael, the central figure, clad in closely fitting mail, is the picture of youthful vigor, grace, and dignity. In his outstretched right hand, stayed after the victory, is a flaming sword; his left points heavenward. Around him, in the golden clouds, are figures of youths of a like, but perhaps a lower beauty, who regard him with love. The defeated evil spirits, writhing below are prone in agony; hideous faces they are, heads with pointed ears and the wings of bats, bodies in contortions unearthly and muscles distorted in an exaggerated way. . . The picture strongly reminds one of the pictures by Rubens in the gallery at Munich. . . . . The contrasts of sentiment, like those of color, are in keeping, yet strong. Above is a golden light and clouds; happiness, beauty, grace, purity, and serene dignity; below is a baleful glare, murky color, pain, hideousness, every thing to tell of the overthrow and punishment of misdirected, evil power. There is probably not another Solimena in America." 
I20. J. H. Caliga, Boston.

A Philosopher.

I2I. Patty Thum, Louisville. (See No.35.) Roses.

122. M. F. H. De Haas, N. A., New York. (See No. 83.) * Marblehead Neck, Mass.

(Illustration, page xi.)

Marblehead Neck, Massachusetts, by M. F. H. De Haas, N. A., was painted for the Louisville Exhibition of Art Union pictures, and represents Mr. De Haas at his best. The sky is full of moving clouds, and one can fairly feel the force of the waves dashing against the rocks.-The Art Union, June, 1884 .

123. De Scott Evans, Cleveland, O.

B. Boston, Ind., I847. Opened a studio in Cleveland, I874, and turned his attention to portrait painting. In $1877-78$ studied under Bouguereau in Paris. Member of the American Art Union. *The Birthday Card.

124. Arthur Parton, N. A., New York.

B. Hudson, N. Y., I842. Pupil of William T. Richards, of Philadelphia. First exhibited in Pennsylvania Academy of Fine Arts, I862. Elected Associate Member of the National Academy, New York, I872; member, I884. Member of the American WaterColor Society and the American Art Union.

Parton's pictures combine careful realization with breadth of treatment. His landscapes take the spectator into the fields, under the trees, and beside the running brooks. -Louisville Spectator, 1883 .

* Nightfall.

(Illustration, page xvii.)

"Now came still evening on

And twilight gray."

... One of Mr. Parton's most charming paintings. ... A remarkably luminous sky tinged with golden sunset color in to which the shadows of evening are creeping. It almost seems as if one could see the colors gradually changing, as the sun sinks lower beyond the hill, and the new moon appears to grow brighter. The poetic sentiment pervading the picture impresses one strongly. It suggests the quiet contemplation we find in Gray's Elegy, and leads one very far away from the busy world.-The Art Union, June, 1884.

\section{Herman Simons.}

In Full Cry.

Mrs. P. WoOLdRIDGe, Louisville. 
126. Jules Tavernier.

Best known to Americans for his illustrations.

Young Shepherd and Sheep. Dr. J. R. Leaming, New York.

\section{I27. Matthew H. Jouett.}

B. I790, in Kentucky. Graduated at Transylvania University, Lexington, Ky., and then studied law. Fought in the War of I8I2, after which turned his attention to art, becoming for a short time a pupil of Gilbert Stuart, between whom and himself there was an intimate friendship. Mr. Jouett painted the portraits of many of the most prominent Southerners of his time. D. 1827 , at Lexington, $\mathrm{Ky}$.

Portrait of Henry Clay. Mrs. J. M. Reed, Louisville.

I28. Signor Manzuoli, Florence.- $\Lambda$ fter Raphael.

The Madonna della Sedia.

Original in Pitti Palace, Florence.

The frame of this picture is an exact copy of the frame of the original picture.

Mrs. J. M. ReEd, Louisville.

Raphael Santi was born at Urbino, Italy, I483. Pupil, at first, of his father; later of Luca Signorelli and Timoteo Viti, and finally of Perugino, at Perugia. It would be impossible to refer even to the important events in Raphael's life in the space at command; it is sufficient to say that he was the greatest painter of his time, and many consider that the world has produced no other artist equal to him. He was not only a good artist, but a highiy cultured man, and made friends every where. Vasari writes; "Nature having been conquered by art through the hand of Michael Angelo, was in Raphael conquered by Art and manners together." Raphael died in I520, and was buried in the Pantheon of Agrippa, in Rome.

The Madonna della Sedia is one of the principal works of Raphael. SPRINGER thus writes of it: "In this picture, Raphael returns to the early and simple subjects of representation, breathing nothing but serene happiness; which gladden the artist and charm the beholder; which say little, and yet possess such deep significance. . . A At least fifty engravers have tried their skill upon the Madonna della Sedia, and photographic copics have been disseminated by thousands. No other picture by Raphael is so popular, no other work of modern art so well known."

I29. Henry Inman.

B. Utica, N. Y., I802. Studied under John Wesley Jarvis, in New York. Went to Europe in I845, living in England for a year, and painting portraits of Wordsworth, Macaulay, Dr. Chalmers and others. Also painted genre and landscape. D. I846.

Portrait of John James Audubon.

Miss H. B. Audubon, Louisville 


\section{Eastman Johnson, N. A., New York.}

B. Maine, 1824. Began his profession -by executing portraits in black and white when little more than a mere boy. He went abroad and studied for two years in Düsseldorf, subsequently studying in Italy, Paris, and Holland. He remained four years at the Hague. Returned to America and opened a studio in New York in 1860. Elected a member of the National Academy the same year. Member of the Society of American Artists and American Art Union. Among his earlier works were many representations of quaint domestic and negro life, among which nore is better known than his "Old Kentucky Home," which has been lithographed, engraved, and "chromoed" again and again. Mr. Johnson has latterly devoted much of his time to painting portraits, and invariably produces a painting interesting for its composition and technique even to one entirely unacquainted with the subject of the picture. His later method of painting is not unlike that employed by the London artist, Millais, solid in the lights and thin and transparent in the shadows. His portraits are held in high esteem and his talent is in great demand.

Mr. Johnson's subjects are carefully studied, and are always expressive of genuine feeling. No one has more decided individuality and independence in choice and treatment of subject than this artist. His pictures bear the unmistakable stamp of originality. We are never reminded in them of the influence of schools or foreign methods; they rest upon their own merits, and the only comparisons they suggest are those afforded by the truths of naturc.-PROF. WeIr.

\section{*The Funding Bill-Portraits of two Gentlemen.}

(Illustration, page viii.)

Two friends of the artist were one day sitting in his library deep in the discussion of some interesting topic. Impressed by their attitudes and expressions, Mr. Johnson made a rapid sketch of them and subsequently had them pose for this picture. When it was finished it was sent to the National Academy (to the exhibition of 188r). For lack of a better title for the picture, it was christened "The Funding Bill," this bill having been passed only a short time before, and being the then prevailing subject of conversation.

There is a great deal of animation in the figures, which are painted with a boldness and firmness born of consummate knowledge, and a feeling of certainty in the artist, at the outset, of his ability to accomplish what he set out to do. There has been no experimenting here; the design was fixed in the mind first, and then every stroke of the brush did its duty, no more no less. The result is a painting of freshness and strength in its lights, of depth in its shadows, and realistic quality throughout.-National Academy Notes, $18 \delta$ I.

131. Hermann Hartwich, Munich.

October in Italy. Grady \& M'Keever, New York. 
132. John La Farge, N. A., New York.

B. New York. Member of the National Academy of Design, American Water-Color Society, and Society of American Artists. Elected National Academician, 1869.

La Farge goes to art with earnest devotion, and an ambition for its highest walks, bringing to the American school depth of feeling, subtlety of perception, and a magnificent tone of coloring, united to a fervent imagination which bestows upon the humblest object a portion of his inmost life. His landscapes are gems of imaginative, suggestive, and delicate vital treatment, not pantheistic in sentiment, although the soul of Nature breathes in them.Jarves, Art Idea.

Landscape, Autumn.

133. Otto H. Bacher, Cleveland, O. (See No.37.) * Interior of St. Mark's, Venice.

(Illustration, page xxxvi.)

A view from the right aisle, looking toward the Main Altar, excellently showing the effects of light from different directions falling upon the marble columns and across the walls covered with mosaics of gorgeously colored figures on golden ground.

I34. J. H. Witt, New York.

B. Ohio. Began the study of Art in Cincinnati, O., in r862. First exhibited in the National Academy, I868.

A painter of great versatility in manner and in choice of subjects. He has been criticised for "painting in the manner of" half a dozen different foreign masters with whom he has been credited as having studied, yet Mr. Witt has never been abroad. He is a close observer of Nature, paints what he see as nearly as possible as he sees it, and generally produces something not only truthful but bright and pleasing.

At Home.

Morston ReAm, New York.

$(\$ 450$.

(Illustration, page $\mathrm{xxxi}$.)

135. Richard W. Hubbard, N. A., New York.

B. Middletown, Conn. President of the Brooklyn Art Association, member of the National Academy (elected 1858), and the American Art Union.

Mr. Hubbard is particularly pleasing in his treatment of summer landscapes and afternoon skies, in which class of subject his art is attractive and often brilliant in its rendering of light and atmosphere, yet with a quiet and subdued tone. His style is not always equal, but it is expressive of true artistic sensibility and sincere motive.-PROF. WE1R-Report on Art at the Centennial, 1876 .

*View from the Overlook, Catskill Mountains. 
136. George F. Fuller, New York. (See No. 95.) * A Forest in Normandy.

One of the most important works of this artist.

137. W. Hamilton Gibson, New York.

B. Sandy Hook, Conn., I850. Never had any art instruction, but about ten years ago turned his attention to illustrating, and now is one of the best-known illustrators in the country. He is the author of several books and the illustrator of many. Mr. Gibson is a member of the American Water-Color Society, the Salmagundi, Sketch Club, and the American Art Union.

*A Reminiscence of the Housatonic.

(Illustration, page $\mathrm{xl}$.)

This is not a "finished picture," but is merely a "memorandum," rapidly painted-for the most part with a palette-knife-of an effect seen by the artist one afternoon last summer.

138. Joseph R. Woodwell, Pittsburgh, Pa. (See No. 27.) Narragansett Bay.

J. J. Gillespie, Pittsburgh, Pa.

$(\$$ Ioo. $)$

139. Bertha Von Hillern, Boston.

Began her career as an apostle of physical culture ; later turned to art and literature. She studied anatomy with Dr. William Rimmer, modeling with the sculptor J. II. Bartlett, and enjoyed the criticism and instruction of William M. Hunt, of Boston. The Monk Felix.

A more magnificent piece of wood painting has rarely been shown in this country, and it is questionable if any foreign artist has successfully attempted so massive a treatment of a forest interior, with its sense of cool repose. Not less in its spiritual than in its poetic treatment has the artist grasped the subject with wonderful strength. Through the vista of trees, the gray stone convent is revealed, while the monk, bowed over his book, seems actually to move in the foreground. Over all there is an air of quiet that seems almost sacred.-Philadelphia Ledger.

140. John James Audubon. (See No. I I5.) The Marsh Wren.

Miss H. B. Audubon, Louisville.

I41. George C. Lambdin, Philadelphia. (See No. Io.) * Roses.

Mr. Lambdin devotes a great deal of time to the cultivation of fine roses, in his garden, in Germantown. He paints roses with a deep love for his subjects, and succeeds in giving his counterfeit roses all the crispness, softness, and delicacy of the originals. They only lack fragrance to deceive one, but they possess an advantage over the real roses, in that they never wither or fade. 
142. W. T. Smedley, New York.

B. Chester County, Pa., 1858. First exhibited, National Academy of Design, 188r. Member of the Society of American Artists, American Water-Color Society, and the Salmagundi Sketch Club. Studied art without a master.

Born Tired.

143. Charles Lanman, Washington, D. C.

B. in Michigan, 1819. Pupil of A. B. Durand, N. A. Elected Associate member of the National Academy, I842. A large portion of Mr. Lanman's time has been devoted to literary pursuits, and for many years he was connected in an official capacity with the Japanese Legation in Washington. Member of the American Art Union.

*An Autumn Afternoon.

144. George H. Story, A. N. A., New York. (See No. II8.) *The Friends.

A picture pleasing in subjects and composition, and opulent in rich coloring.

I45. Henry A. Ferguson, A. N. A., New York.

B. Glenn's Falls, N. Y. Studied in Albany, New York City, Paris, and Venice. Has visited many countries on sketching tours, his portfolio being particularly rich in Italian and Mexican studies. Elected Associate Member of the National Academy, r884. Member of the American Art Union.

* Spanish Church and Market, Orizaba, Mexico.

\section{I46. Emile Vernier.}

B. Sous-le-Saunier. Honorable Mention, Salon of 1878 , ancl Medal, Salon of 1879 .

A Canal in Cairo.

Joseph W. Wayne, Cincinnati.

I47. Edgar M. Ward, N. A., New York.

B. Urbana, O. Pupil of National Academy of Design, New York, l'Ecole des Beaux Arts and Cabanel, Paris. In Paris I872-I879. Elected Member of the National Academy, i883. Member of the American Art Union.

Ward has studied conscientiously, and the character of his work, in almost any light in which it may be viewed, will stand the test of comparison with the pictures of the leading artists represented in the exhibition.--Art Journal, May, I885. (On National Academy Exhibition.)

* A Fisherman's Cottage, Trepont, Normandy.

(\$350.) 
I48. John M. Tracy, Greenwich, Conn.

B. Rochester, O., 1844. Began the study of Art with A. L. Rawson, of Chicago. In 1867 went to Paris and studied in the Beaux Arts, and in the studios of Adolphe Yvon, Isidor Pils and Carolus Duran. Member of the American Art Union.

* A Point on Ruffled Grouse.

A portrait of the celebrated setter "Grousedale," which won the prize in the "Eastern Field Trials" in I88r, and several other prizes over imported dogs.

149. Alfred Kappes, New York.

B. New York City, 1850. Self-taught; has never been abroaa. First exhibited at National Academy of Design, 1874, and has been a regular contributor to nearly all exhibitions since. Is noted for his vigorous technique and strong effects.

A Fruit-Seller.

150. Lizzie F. Boyce, Louisville. (See No. 34.) A Eucharist Lily.

I51. Lemuel E. Wilmarth, N. A., New York.

B. Attleboro, Mass., 1835. Pupil of the National Academy of Design, New York; then (1859-1862) in Royal Academy of Fine Arts, Munich, under Kaulbach; 1864-1867 in Paris-in l'Ecole des Beaux Arts and with J. L. Gerome. Elected Member of the $\mathrm{Na}$ tional Academy, 1872. Now Director of the Schools of the National Academy of Design, New York. Member of the American Art Union.

One of the most painstaking artists belonging to the National Academy. His style of coloring is brilliant, and in his manner of manipulation his pictures are suggestive of the French school, but suggestive in no way to impair their individuality.-Art Journa?.

* Jack's Return.

A picture which tells its story very completely.

152. Paul Weber, Munich.

B. in Germany, I823. Studied in Frankfort. In 1848 came to the United States and settled in Philadelphia. Returned to Europe in I858, and was appointed Court Painter at Darmstadt. Lately he has resided in Munich.

Sheep Going to Pasture.

HARrison EARL, Philadelphia. (\$450.) 
153. Andrea Marko, Florence, Italy.

The Claudian Aqueduct.

MrS. J. M. REeD, Louisville.

154. Shackelford.

Portrait of General Robert E. Lee.

ERnest Viel, Louisville.

(\$200.)

I55. A. Carte, Naples.

Holy Family.

Mrs. J. M. ReED, Louisville.

156. Zuber Buhler.

First Love.

James S. Earle \& Sons Philadelphia.

(\$800.)

I57. J. G. Brown, N. A., New York.

B. England, 1831. Studied in Newcastle-on-Tyne and in Royal Scottish Academy, Edinburgh; later, with Thomas Cummings, $N$ A., New York. Elected member of the National Academy, I803.

Mr. Brown's subjects are derived from the homely incidents of every day life, and are usually treated with simplicity and naturalness. His realistic powers are marked.-PROF. WEIR.

A Flower Girl.

158. G. W. Morrison, Louisville.

B. Baltimore, Md. Studied Art early in life in the Pennsylvania Academy of Fine Arts, Philadelphia. Enjoyed studying Joseph Bonaparte's collection of paintings, at Bordentown, N. J., in 1844, and has been a student of Nature ever since that time.

Apples and Nuts.

159. Peter Moran, Philadelphia. (See No. 99.)

*The Downs, York Harbor, Me.

r6o. Edward L. Henry, N. A., New York.

B. South Carolina, I84r. Studied in the Pennsylvania Academy of Fine Arts, Philadelphia, and with P. Weber; afterward in Paris, under Suisse and Courbet. Elected member of the National Academy, 1870. Member of the American Art Union.

Approaches, in the delicacy of his finish and in the brilliancy of coloring of his pictures, nearer to the style of Meissonier than any other artist in this country.-Art Journal, April, s875.

* "Worn Out."

$(\$ 100$.

16I. C. Hernandez.

Summer-time.

Grady \& M'Keever, New York.

(\$75.) 
162. Frederick Schuchardt, jr., New York.

B. New York City, 1856. Pupil of William Morgan and J. G. Brown. First exhibited in the National Academy, 1877. Member of the American Art Union.

* Evening.

$(\$ 600$.

(Illustration, page $\mathrm{xv}$.)

"And all the air a solemn stillness holds."

A crimson-purple, misty sky in which the sun, a glowing crimson disk, is gradually sinking. The water repeats the color of the sky, and the figures, on the bluff add a harmonious interest to the picture.

This picture was greatly admired at the National Academy Exhibition this year. A wealthy connoisseur selected it for his gallery early in the exhibition, but the Wall Street upheaval threw it back into the hands of the artist.

163. John Mulvany. (See No. I2.)

In the Black Hills.

Charles Fleischmann, Cincinnati.

164. Edward Weber.

Outward Bound. (Moonlight.)

James S. Earle \& Sons, Philadelphia. (\$9o.)

165. E. R. Maes, Brussels. $A$ Group of Chickens.

George H. Moore, Louisville.

166. A. Zingoni, Florence.

A Florentine Chimney-Sweep. Mr. J. M. REED, Louisville.

167. D. Baron.

A Cozy Place.

J. M. Robinson, Louisville.

168. George H. Yewell, N. A., New York.

B. Havre de Grace, Md. Pupil of the National Academy of Design, and Thomas Hicks, N. A., New York, and Thomas Couture, Paris. Studied in Paris, 1856-1861. In Italy and Egypt, living variously in Rome, Venice, Perugia, and Cairo, I867-1878. Elected member of the National Academy, I880. Member of the American Art Union.

Paints with great fidelity and accuracy.-Mrs. TytLer, Modern Painters. *A Ferry on the Grand Canal, Venice.

I69. Frank Waller, New York. (See No. 43.)

* A Pair of Hop Pickers. 
I70. James Renwick Brevoort, N. A., New York.

B. Westchester County, N. Y., I832. Studied architecture in New York under James Renwick, but turned his attention to painting, and became a pupil of Thomas Cummings, N. A. For two years he was Professor of Perspective in the National Academy, New York. 1873-1880 in Europe, studying in various countries, but spending most of his time in Florence. Elected member of the National Academy, I 863. Member of the American Water-Color Society and the American Art Union.

Brevoort's landscapes are broad and thoughtful, with pleasing atmospheric effect.-Tuckerman, Book of the Artists.

* A Day in October.

I7r. Francis D. Millet, New York.

B. Mattapoisett, Mass., I846. Studied in the Royal Academy at Antwerp under Van Lerius and De Keyser, gaining the silver and gold medals of honor in 1872 and 1873 . Has practised his profession in the United States, Belgium, England, Italy, France, and Austria. Was the American Art Juror at the Paris Exposition of I878, and has distinguished himself as a journalist both in America and Europe. At one time was the War Correspondent of the London Daily Neres.

\section{Reading the Story of Enone.}

The Letroit Art Loan Association.

Enone, daughter of Cebren, the river god, was a nymph of Mount Ida, and had the gift of prophecy. She told her husband, Paris, that a visit which he proposed to make to Greece would involve both himself and his country in ruin. Paris, however, made the visit, and becoming enamoured of Queen Helen, wife of Menelaus, King of Sparta, eloped with her. This brought about the Trojan war. When Paris was wounded by an arrow from the bow of Philocletes, he sent for his wife Enone, who hastened to him, but too late. When the dead body of old Priam's son was laid at her feet, she stabbed herself.

Tennyson has written a poem on Enone, in which he makes the deserted wife cry out her grief to "Mother Ida," the mountain on which she liver. Here is one despairing verse which is characteristic of the whole poem:

"O mother, hear me yet before I die.

Hath he not sworn his love a thousand times,

In this green valley, under this green hill,

Even on this hand and sitting on this stone?

Sealed it with kisses? Watered it with tears?

O happy tears, and how unlike to these!

O happy heaven! how canst thou see my face?

O happy earth, how canst thou bear my weight?

O death, death, death, thou ever-floating cloud,

There are enough unhappy on this carth, 
Pass by the happy souls that love to live;

I pray thee pass before my light of life,

And shadow all my soul that I may die.

Thou weighest heavy on the heart within,

Weigh heavy on my eyelids; let me die."

There is also a poem by Professor Aytoun, a verse of which in like manner reveals the grief of Enone over the loss of Paris.

The picture, Reading The Story of Enone was first exhibited in the $\mathrm{Na}$ tional Academy last year; later it was one of the attractions of the Art Loan Exhibition at Detroit, Mich. It became so popular there that it was purchased by the Loan Association as the nucleus of a permament collection of paintings for the proposed Detroit Museum of Art. The following critical notice of the picture is from the Louisville Courier-Journal, of August 24, I884:

The picture is a beautiful idealism; a symphony in delicate shades of pink and brown, judiciously harmonized with colors of a deeper, richer tone. Mr. Millet is an authority on classic drapery and costumes, and in this picture has turned his knowledge to good account. Four women are seated on Grecian couches, or klinai, which are placed against the wall of the room. The central figure, the tallest and most commanding, reads the sad story of Enone to the other three, who have assumed various attitudes of interest and attention. The two figures on the ends are draped each in a single transparent garment of pink; that on the right is a more delicate shade of pink, finely relieved by the purple, gold-embroidered cushions on which the woman's arm rests. The two central figures are of a darker type, and their garments are heavier and darker, almost an olive brown. They, too, are supported by cushions, though the reader sits erect. The cover of the divan is of a light buff color, with white stripes running through it. The wall behind is gray in tone; the floor on which the feet of the women rest is of marble. The picture is technically remarkable for its fine modeling, delicate and harmonious coloring and the painting of the various textures. She who reads the story to the others, sitting noble, erect, her brows and dark hair bound with the flowering laurel, might be a type for Pallas; her dark eyes flash and melt as she tells the tale. Next to her sits one whose grace and rapt attention suggest that she might almost be the "beautiful-browed Enone," or had dreamed of one "white-breasted like a star." The woman on the extreme left is also listening intently to the reader. IIer clear, white skin shows through the pink folds of her gown; her auburn hair is bound with a broad fillet of a deeper pink than her dress, and her brown eyes look wonderingly at the reader. Though these threc women all differ in type and expression, the girl on the right of the picture is still further removed from the others, both in space and in sentiment. . . . Her blue eyes are full of a dream that is not suggestive merely of sympathy for the "Mournful Enone;" the woes of fair Helen seem to have found a place in her heart. The luxuriousness of her pose, the rich purple of the cushions that embrace her arm, bound with a serpentine armlet of gold, the drapery, half concealing, half revealing her fair form, all proclaim that she has a human sympathy with him who awarded the prize of beauty to the Goddess of Love

I72. Edward Moran, A. N. A., New York.

B. Bolton, Lancashire, England, 1829. Came to America, 1844 . Began the study of art at the age of sixteen. Pupil of Jas. Hamilton 
and Paul Weber. First exhibited at the Pennsylvania Academy, 1852. Went to Europe, 1862, and studied in National Gallery, London. Returned to New York, I869. Elected Associate member of the National Academy, 1873. Member American WaterColor Society.

EDWARD MORAN seems to be constituted peculiarly for an artist, for with quick perceptive faculties and a mind capable of reflection, the task of transscribing and translating. with truthfulness the simple beauties and refincd grandeur of the land and sea has not been to him an irksome toil, but has proved a pleasure; consequently his pictures have in the highest degree the quality of imparting delight to others. An appreciative observer can not fail to regard them as faithful and intelligent interprctations of the truth and the sentiment of ever-varying nature.-Philadelphia Evening Bulletin.

Moonlight, New York Bay.

N. Sarony, New York. (\$2,000.)

One of the finest pictures Mr. Moran has painted. One who has sailed up New York Bay by moonlight will recognize the scene in land-mark, form, color, and incident. There is admirably expressed motion in the clouds and in the water. The drawing throughout is most excellent and every stroke of color is laid on with consummate knowledg

r73. Oswald Achenbach, Düsseldorf.

B. Düsseldorf, 1827. Brother and pupil of Andreas Achenbach. Chevalier of the Legion of Honor. Devotes himself largely to I talian scenes. Medals, Paris I859, I86I and I863.

The Bay of Naples. A. D. Vorce, Hartford, Conn.

(\$600.)

I74. Frank Waller, New York. (See No. 43.) * A Venetian Sail.

I75. F. De Beul, Brussels.

Shepherd and Sheep.

Geo. H. Moore, Louisville.

A charmingly realistic picture.

176. J. G. Brown, N. A., New IJork. (See No. 157.) A Joint Investment.

Geo. H. MOore, Louisville.

This painting by Mr. Brown is one of the few pictures in this collection exhibited last year. It was so very popular then that the Art Committee felt that visitors to the gallery would be glad to have a further opportunity for becoming acquainted with it.

177. C. A. Platt, New York. (See No. 38.)

Old Court at Honfleur, France.

(\$IOO.)

I78. William Hart, N. A., New York. (See No. 29.) Autumn.

Major J. C. F. Allen, Louisville.

A painting in Mr. Hart's earlier manner, with luminous sky, fine atmospheric effect and superb coloring. 
I79. N. Sarony, New York. See No. I.)

An Odalisque. (Crayon.)

Exceedingly artistic in composition, fine in drawing and excellent in the representation of qualities.

180. Charles Warren Eaton, New York. (See No. 57.) After Sundoren.

A most poetically suggestive picture, broad in technique, and exceedingly realistic.

I8I. Albert Bierstadt, N. A., New York. (See No. 30.)

The qualities which strike us in Mr. Bierstadt are, first, a great audacity justified by perfect ability to accomplish all he intends. He is not a mere copyist of nature, but an artist having definite artistic intentions, and carrying them out with care and resolution. He is always trying for luminous gradations and useful oppositions, and reaches what he tries for.-London Saturday Review.

* The Wahsatch Mountains.

$(\$ 2,500$.)

The realistic treatment of the foreground, the excellent atmospheric quality and fine effect of distance, the bright, luminous sky, and the mountain half enveloped in the clouds, with the gleam of light on the water in the middle distance, all contribute to make this one of the most pleasing of $\mathrm{Mr}$. Bierstadt's recent pictures.

182. John Mulvany. (See No. I2.) Consolation.

Major W. H. Thomas, Louisville.

183. De Haguemann.

The Seraglio Garden.

Mrs. P. WOOLDRIDGe, Louisvil!e.

I84. E. Dietrich, Vienna.

B. Germany. Imperial Court Painter of Vienna. Took first prize at Vienna Exposition.

Head of Christ, illustrating the Legend of St. Veronica.

General D'Utassy, Cincinnati.

The legend is that Christ, bearing His cross on the way to the place of crucifixion, passed the house of Veronica, who, pitying his sufferings, gave Him a cloth to wipe His brow. When He returned it to her, His sacred lineaments were impressed upon it. This story is recognized by the Romish church. There are various versions of the story, substantially the same, however, regarding the miraculous picture on the cloth.

This picture was imported by Archbishop Purcell, shortly before his failure. A publisher paid $\$ 500$ for the privilege of making a chromo from it.

185. Albert Bierstadt, N. A., New York. (See No. 30.) * Autumn near IVaterville, $N$. $Y$. 
186. Percival De Luce, New York.

B. New York City. Pupil of the Academy at Antwerp; Portaels, Brussels, and Lèon Bonnat, Paris. First exhibited in the National Academy, New York, I872. Member of the American Art Union. * The Knitting Lesson.

$(\$ 400$.

A charmingly painted picture of home-life.

187. L. Toussaint, Düsseldorf.

The Englishman on his Travels.

George H. Moore, Louisville.

x8. Otto H. Bacher, Cleveland, O. (See No.37.) * Venice from San Georgio.

(\$400.)

As bright and sparkling as a picture by Rico. Shows the Doge's Palace, the Campanile, the entrance to the Piazza San Marco and the domes of the famous Cathedral, the Bridge of Sighs and the prison, the Royal Gardens and the Hotel Danieli.

I89. Louis H. Burr, New York.

Studied in New York and abroad. Member of the American Art Union.

* Beneath his Notice.

Igo. Charles H. Miller, N. A., New York.

B. New York, I842. First studied medicine, graduating in 1863. Turned his attention to art, and studied in the Bavarian Royal Academy, I867, and for three years with Adolph Lier (pupil of Dupre), Munich. First exhibited, National Academy, I860. Elected National Academician, I875. Member of the Society of American Artists, New York Etching Club, and American Art Union.

Miller's pictures show decided merit, with a strong foreign accentuation.PROF. WEIR.

*The Poet's Mill, Long Island.

Igr. Martin J. Heade.' (See No. 82.)

Sunset, St. John's River, Florida.

Reichard \& Co, New York. (\$200.)

192. Seymour J. Guy, N. A., New York.

B. England, I824. Studied art in England for a number of years, and came to America in 1854. Was elected National Academician, 1865. Member of the American Water-Color Society and the American Art Union. 
Mr. Guy's subjects mostly relate to scenes and incidents drawn from childlife, and in their composition and treatment he has no supcrior in American Art. His style is fresh and unconstrained, and is marked by great richness of coloring and delicacy of finish.-Art Journal, September, 1875 .

* Open your Mouth and Shut your Eyes.

$(\$ 1,500$.

I93. Albert T. Bricher, A. N. A., Southampton, L. I.

B. Portsmouth, N. H., I837. In $185 \mathrm{I}$ he entered a mercantile house in Boston, painting and studying art in leisure hours without instruction. In 1858 began the practice of Art as a profession, and painted in Boston for ten years. In I868 settled in New York. Summer studio at Southampton, L. I. Elected Associate of the National Academy, I879. Member of the American Art Union.

Bricher, although among the younger men belonging to the American school of painting, has already assumed a leading position as an artist, not only as a marine painter but in the delineation of landscapes.-Art Journal, 1875 .

In Gloucester Harbor, Mass.

Grady \& M'Keever, New York.

$(\$ 250$.

194. Carl C. Brenner, Louisville. (See No. 7I.) * A Summer Afternoon.

I95. Eva B. Smith, Louisville.

A Hibernian. (A study from Life.)

196. Guillaume.

$A$ Vase of Flowers.

James S. Earle \& Sons, Philadelphia.

$(\$ 150$.

197. Andrea Marko, Florence, Italy. Serevezza Peak, Carrara Mountains.

Where the purest white marble for statuary is quarried.

MrS. J. M. ReED, Louisville.

198. William Bliss Baker, New York.

B. New York. Pupil of the National Academy of Design, New York. First exhibited in the National Academy in 1879. Third Hallgarten Prize in the National Academy exhibition of this year.

A young man of remarkable talent. Keenly perceiving the facts of Nature, and seeing beyond the bare facts with a wonderful ability to reproduce what he sees as he sees it, and to convey to the spectator all the impressions which come to him, Mr. Baker gives promise of becoming one of the greatest landscape painters of the time. His pictures already are attracting wide attention.

Landscape. 
199. Constant Mayer, A. N. A., New York.

B. Besançon, France, I83I. In his early youth went to Paris ancl entered the schools of the Beaux Arts, also becoming for a time a pupil of Léon Cogniet. He resided in Paris until 1857, when he came to America, where he has lived ever since. His great specialty has been in genre pictures, and his works have been exceedingly popular, many of them having been photographed and engraved. Mr. Mayer was elected an Associate of the National Academy, New York, in 1867, and received the Cross of the Legion of Honor from Napoleon III in 1869.

\section{*The Charmer.}

$(\$ 400$.

One of the freshest and brightest of Mr. Mayer's pictures. The happy, joyous expression of the face is in strong contrast with the sadness in the face of the Evangeline and that of the woman in The Song of the Shirt, in another gallery.

200. James Burrell. A Marine View.

Hegan Brothers, Louisville. (\$5

201. Hermann Fuechsel, New York.

B. Brunswick, Germany, 1833. Studied first in the Collegium Cardinum, at his native place, under Prof. Brandes, and in 1852 received the first prize of that institution. In 1855 he went to Düsseldorf with a letter of introduction to Prof. C. F. Lessing, whose pupil and intimate friend he afterward became. In $185^{8}$ he sailed for America, and since that time has resided in New York.

* The Trysting Place.

It is the hour when from the boughs

The Nightingale's high note is heard;

It is the hour when lovers' vows

Seem sweet in every whispered word.

BYron. 


\section{Dictures itt the giorth Gaflern.}

202. Morston Ream, New York. (See No. 66.) Fruit and Wine.

203. Walter Shirlaw, New York.

B. Paisley, Scotland, I837. Was brought to America in I840, and early began the study of art. He studied in Munich for a number of years, under Professors Rabb, Wagner, Ramberg, and Lindenschmidt, eminent men representing various schools there. His professional life has been spent in Chicago, Munich, and New York. Elected member of the Chicago Academy, 1878, and later of the National Academy, New York, but resigned his membership in the latter association. Professor of Drawing and Painting in the Art Students' League, New York. Member of the American Art Union.

One of the best draughtsmen and finest colorists in the country. His compositions are always thoroughly artistic; well balanced in light and shadow masses, coherent and harmonious in their various parts. What would be secured only after deep study and experimenting by some men, seems natural to Mr. Shirlaw, in whose paintings one is not constantly impressed with the evidence of a tremendous amount of painfully sustained labor, tiring one to think of it all, but rather, one feels a sense of exhilaration in contemplating the free, fresh, vigorous productions of his brush. Mr. Shirlaw's art is that satisfactory art which conceals art. His pictures differ from the carefully painted pictures of many other artists just as brilliant extemporaneous eloquence is usually more forceful and effective than carefully studied periods. Louisville Courier-Journal.

*Puss。

(Illustration, page vi.)

204. Francis Miller, New York.

B. Columbus, Ohio, 1854. Studied in the Pennsylvania Academy of Fine Arts, and was a pupil of Carolus Duran, Paris. First exhibited, National Academy of Design, New Vork, 1883. 
"What Shall I Write?"

(\$290.)

One of the most carefully and realistically painted pictures in the collection. Note the rendition of qualities in the various objects.

205. M. De Forest Bolmer, New York.

B. Yonkers, N. Y., I854. First exhibited in the National Academy, New York, I877. Member of the American Art Union.

* Springtime.

Broadly painted and effective landscape, with excellent sky and atmosphere.

206. G. H. M'Cord, A. N. A., Morristown, N. J.

B. New York, I 849. Pupil of Professor Moses Morse. First exhibited, National Academy, I868. Elected Associate of the National Academy, I880. Member of the American Water-Color Society and of the American Art Union.

* The Ice Harvest.

$(\$ 550$.

(Illustration, page xxi.)

A winter twilight; scene near Morristown, N. J. A peculiarly luminous sky and brilliant color effect.

207. Carl C. Brenner, Louisville. (See No. 7I.) Gateway to the Garden of the Gods.

George H. Moore, Louisville.

208. Maria J. C. Becket, Boston.

B. Portland, Me. The great fire in that city destroying her home and causing the death of her father, she removed to Boston and entered upon the study of art. Studied with William M. Hunt, in Boston, and with Daubigny, in France, enjoying the exceptional privilege of painting with the latter in the country, in his boat on the river Oise, and of living in friendly intimacy with his family. Has also studied in Germany and Italy; spent some time in Rome. On the Border of the Forest, Front Royal, Va.

$(\$ 400$.

209. Walter Shirlaw, New York. (See No. 203.)

* Tuscany Vase with Flowers.

$(\$ 200$.

A most brilliant piece of coloring; strikingly realistic when viewed from the proper distance.

210. J. H. Dolph, A. N. A., New York.

B. Fort Ann, New York, I835. Pupil of Louis Van Kuyck, Antwerp. First exhibited in the National Academy, IS64. Elected Associate of the National Academy, I877. Has lived in Paris and 
New York at intervals during the past ten years. Member of the Society of American Artists and the American Art Union. *The Master's Chair.

One of Mr: Dolph's most carefully painted pictures, showing him at his best. Rich in color and pleasing in composition.

\section{Ir. J. Wells Champney, A. N. A., New York.}

B. Boston, Mass., I843. Entered the studio of a wood-engraver at the age of sixteen. Afterward pupil of Edouard Frere, Ecouen, France, I867 and 1869; Academy at Antwerp, I868; in Rome, 1869-1870; in Northern Spain, 1874-75. Lecturer on Anatomy in the schools of the National Academy of Design. Member of the American Water-Color Society, the Salmagundi Sketch Club, and the American Art Union. Elected Associate of the National Academy, I882.

* A Rosebud Among the Daisics.

A quiet, unobtrusive picture in which there is much genuine merit.

212. George Inness, N. A., New York.

B. Newburg, N. Y., 1825. Studied art in Newark, N. J., and engraving in New York. In 1846 began landscape painting as a profession, spending a month meanwhile in the studio of Regis Gignoux. Visited Europe several times for purposes of observation and study, and lived in Italy from 1871 to 1875 . Elected National Academician, 1868. Member of the American Art Union and Society of American Artists.

There is no American artist who has acquired greater fame as such than George Inness, neither can we recall any other who is so varied in his moods. ... In his happy moods he has painted some of the best landscapes produced in this country.-Art Journal, March, 1876 .

Rarely do we see one of his landscapes without finding there a picturesque effect or a subtle meaning indicative of the rarest skill and the most absolute genius.-Tuckerman, Book of the Artists.

There is ever perceptible in his works imagination, feeling, and technical instinct of a high order.-JARves, Art Idea.

A man who has been in intense earnest from the day he began to paint. His art has been his life, the center of his thoughts and dreams, influenced by the exaltation and depression of his moods, but always the fervid utterance of one impelled to deliver his message by the fullness of his heart.-J. R. W. Hiтснсоск. Biographical Sketch of George Inness, N.A.

\section{Sunset.}

The American Art Association, New York. (\$400.)

A charming representation of the sunset glow in the sky, its reflection from the water, and effect upon the whole landscape. 
2I3. Julius Hubner, Düsseldorf.

Professor in the Academy at Düsseldorf.

Celebrating Her Lover's Birthday.

N. A. Franker, Louisville.

214. Harry Chase, A. N. A., New York.

B. Vermont, 1853. Studied in the National Academy of Design, New York, 1870-71; in the Bavarian Royal Academy, Munich, 1872-75; with Soyer, Paris, 1877-78, and with Mesdag at the Hague, 1879. First exhibited in the National Academy, 1878, and in the Salon, Paris, the same year. Elected Associate of the National Academy, 1883. Member of the American Water-Color Society, the Salmagundi Sketch Club, and the American Art Union.

Mr. Chase has few rivals in the rendition of marine views and coast scenes. $\mathrm{He}$ seems to possess many of the best characteristics of both Achenbach and Clays, while at the same time he is intensely original.-Louisville CourierJournal, 1883 .

On the Lower Maas, Holland. Willam Semple, Louisville.

One of the freshest and brightest of Mr. Chase's small pictures.

215. Claude R. Hirst, New York.

Studied in New York; now studying abroad.

Friendship's Tokens.

216. John W. Casilear, N. A., New York.

B. New York. At the age of fifteen began the study of bank-note engraving under Peter Maverick. Afterward turned his attention to painting. Elected member of the National Academy, I85I. Member of the American Art Union.

Casilear's pictures, when sent from the easel, are as harmonious as poems, and it is this perfect serenity in their handling which is so attractive to connoisseurs.-Art Journal.

* Bringing the Cows Home.

The first picture is a bright landscape by J. W. Casilear; a girl driving some cows along a path coming out of the woods. There is a very pleasing view down the pathway, in the shadow of the trees, the distance and atmospheric effect being well realized.-The Art Union, January, 1884.

217. John B. Bristol, N. A., New York.

B. Hillsdale, N. Y., 1826. Studied from Nature at an early age. In 1876 he received an award and medal for his single picture exhibited at the Centennial Exposition at Philadelphia. Elected 
member of the National Academy, 1875. Member of the American Art Union.

Mr. Bristol, as a landscape painter, is well known all over the United States, and his pictures are in all of the leading collections. His country home is among the Berkshire Hills, in Massachusetts, and the beautiful scenery of that region no doubt largely influenced him in choosing that branch of art in which he has since become so eminent. $-N$. Y. Evening Post.

*The Chocorua Mountain.

An exquisite example of Mr. Bristol's best work. The effect of distance is rendered with great subtlety. Fcw pictures contain such superb atmoso pheric.quality

218. Miss A. Klumpke, Paris.

A Beer-Drinker. William Wiswell, Jr., Cincinnati. (\$I50.)

219. Miss Minnie Milton, Louisville. A Portrait from Life.

The Artist.

A young artist of this city, Miss Minnie Milton, is represented by a head that hangs in the north gallery. It is a portrait of a child, rather broadly painted, with good drawing and characteristic expression. The picture promises well for the future of the artist.-Louisville Courier-Journal.

220. Max Weyl, Washington, D. C. (See No. 78.) *Rock Creek.

A charming view on a picturesque stream near Washington, D. C.

221. Louis C. Tiffany, N. A., New York.

B. New York City, I848. Pupil of Cieorge Inness, N. A., and of Leon Bailly, Paris. Has traveled extensively in many countries. Member of the National Academy, American Water-Color Society, the Society of American Artists, and the American Art Union.

On the Nile.

N. SARony, New York.

$(\$ 250$.

222. V. Tojetti, New York. (See No. I Io.) An Oriental Girl.

Another painting by $\mathrm{Mr}$. Tojetti hangs on the West wall of this gallery. It represents an Oriental woman of a rich, luxuriant style of beauty; voluptuous, full of grace, with a charm in every movement. She is one of those rare brunettes with a fresh, transparent complexion. Her dark hair falls over her shoulders in tangled wavelets. Her costume is a loose, flowing affair of pink and blue satin most exquisitely realized in quality. The background of the figure is of a light golden tone, contributing much to the delicacy and richness of the color effect.-Louisville Courier-Journal.

223. Charles T. Phelan, New York.

B. New York City, I 843. Pupil of F. Rondel, sr., A. N. A., New York. Began painting when sixteen years of age, but did not 
embrace art as a profession until some fourteen years later. Exhibits in the National Academy and other New York exhibitions, and his pictures are finding their way into many of the best collections. Sheep in a Stable.

$(\$ 200$.

Somewhat suggestive of the manner of Brissot-the eminent Europcan painter of sheep-and fully equal to his work.

224. W. L. Sonntag, N. A., New York. (See No. 87.) Virginia Scenery.

William Semple, Louisville.

An excellent example of Mr. Sonntag's earlier manner, and one of the most pleasing pictures he has painted.

225. R. W. Van Boskerck, New York.

B. New Jersey, 1855. Pupil of A. H. Wyant, N. A., and R. Swain Gifford, N. A. First exhibited, National Academy, I88o.

Jersey Lowlands. Morston Ream, New York. (\$roo.)

226. F. K. M. Rehn, New York. (See No. 65.)

* Little Good Harbor Beach, Massachusetts Coast.

$(\$ 350$.

227. P. P. Ryder, A. N. A., New York.

B. Brooklyn, New York. Began his profession by painting portraits. Went to Europe in 1869 and became a pupil of Leon Bonnat, Paris. Also studied in Belgium and Holland. Member of the American Art Union.

* "Warming up."

$(\$ 400$.

P. P. Ryder's "Warming up" represents an old man sitting before a kitchen stove, on a cold morning, "warming up" with a cup of hot coffee. The old man's face is full of character, and the various details of the picture are carefully realized.-The Art Union, January, I884.

228. Clarence Boyd.

B. Ironton, Ohio, I855. Pupil of Carolus Duran and Leon Bonnat, Paris. Practised his profession in Louisville. D. IS83.

Falls in Virginia.

Mrs. C. F. Johnson, Louisville.

One of the artist's most successful and pleasing landscapes.

229. Andrew Fisher Bunner, A. N. A., Venice.

B. New York City, I84I. Studied for five years in Germany, France, and Italy. First exhibited, National Academy, I867. Elected Associate Member of the National Academy, 1SSo. W'ent to Venice in 1882 , and is now living there. 
The New Market, Venice.

ReICHARD \& Co., New York. (\$650.)

230. George Hetzel, Pittsburgh, Pa. (See No. 7.)

Fruit. J. J. Gillespie, Pittsburgh, Pa.

(\$300.)

231. Matthew H. Jouett. (See No. 127.) Sketch for a Portrait.

R. J. Menefee, Louisville.

232. M. Mencci, Florence.

Flowers.

Mrs. J. M. Reed, Louisville.

233. Edward Gay, A. N. A., New York.

B. Ireland, 1836. Studied with James M. Hart, N. A., and George H. Boughton. Went to Germany in 1862 and studied under Skinner and Lessing. First exhibited in the National Academy, 1859. Elected Associate of the National Academy, 1870. Member of the American Art Union.

The River Side.

American Art Association, New York.

$(\$ 250$.

234. Seymour J. Guy, N. A., New York. (See No. 192.) * "See Saw, Margery Daw."

(Illustration, page $\mathrm{xxv}$.)

Seymour J. Guy, in "See Saw, Margery Daw," has exquisitely portrayed an incident of home-life under a candle-light effect. A mother is playing with her half-dressed infant, and a child stands beside them with interested expression. As a color composition the picture is exceptionally fine, the gradations being expressed with marvelous subtlety and truthfulness.-The Art Union, April, r884.

235. Jervis McEntee, N. A., New York.

B. Rondout, N. Y., i828. Pupil of F. E. Church, N. A. Elected member of the National Academy, I86r. Member of the American Art Union.

Mr. McEntee's pictures are all characterized by great sincerity and decided poetic feeling. They evince a subdued yet intense enjoyment of those phases of nature that are tinctured with melancholy, and which are therefore none the less beautiful. The artist's style is expressive and sensitive, and, within the scope of his stronger sympathies, mature and confident.-Prof. WEIR.

It would be almost impossible to paint a better expression of a late Octrijer day. The brown landscape and trees all but leafless, under the dull leaden colored sky with the bright gleam of white light along the horizsn, are elements with which one becomes familiar in this country.

* Shadows of Autumn. 
236. Joseph Lyman, jr., New York.

B. Ravenna, Ohio. Studied in Europe I864-I866, and afterward was a pupil of J. H. Dolph, A. N. A., and of Samuel Colman, N. A. First exhibited, in the National Academy, New York, 1876. Member of the American Art Union.

* Newport, Isle of IVight.

Painted broadly, yet carefully and realistically - The Art Union, Tan. 1884.

237. Stephen Parrish, Philadelphia.

B. Philadelphia, 1846 . Began painting in 1877 , and first exhibited in the Pennsylvania Academy of Fine Arts in 1878. Member of the American Art Union and the New York Etching Club. Of high reputation as an etcher.

\section{* November Truilight.}

A November Twilight, by Stephen Parrish, is a picture containing much poetica! sentiment. It shows an uninclosed field on a hill, over which a road leads down to the valley beyond. In the middle-ground an old barn is projected against a bright sky. Some sheep are grazing in the background, and one obtains glimpses of distant hills across the valley. The Art Union, January, 1884 .

238. John L. Fitch, A. N. A., New York.

B. Hartford, Conn., I836. Studied in Munich and Milan under Prof. Albert Zimmermann and his brothers, Max and Richard Zimmermann. First exhibited in the National Academy in 1860. Elected Associate of the National Academy in 1868. Member of the American Art Union.

John L. Fitch has attained eminence as a painter of forest scenes.-Art Journal, April, 1875.

* A Study on the Raimondskill.

239. Harry Chase, A. N. A., New York. (See No. 214.) * Moonlight.

240. W. S. Macy, New York.

B. New Bedford, Mass. Pupil of the National Academy of Design, New York, and of IV. Velten, Munich. In Munich, I874-79. First exhibited, National Academy, 1874. Member of the American Art Union.

Another of our landscape painters who helps to justify the claim that America has taken the lcad in landscape art.-Louisville Spectator, 1883.

Early Winter.

Reichard \& Co., New York. (\$350.) 
24I. Henry A. Ferguson, A. N. A., New York. (See No. 145.) * Landing at Pallanza, Lake Maggiòre.

One of Mr. Ferguson's best pictures; excellent in qualities and atmospheric effect.

\section{Salvator Rosa.}

B. near Naples, 1615. A man of varied talents, being a painter and musician as well as an artist. His masters were Spagnoletto and Aniello Falcone. In 1635, went to Rome, and resided there for the greater part of the time until his death. It is said that in his youth he associated with bandits, and there is an element in his representations of wild scenery and the men he pictures in its midst, that seems to indicate the truth of this. His landscapes are his most characteristic works. Jagged rochs and mountains, wild dells and lonely defiles, with here and there robbers, hermits or soldiers, make his most effective pictures. His works are found in the best of the European collections; they now command enormous prices.

\section{The Trumpeter}

Dr. J. R. Leaming, New York.

\section{Sanford R. Gifford, N. A.}

B. Saratoga County, N. Y., but in his early years his parents removed to Hudson, N. Y., where the greater part of his life was spent. He studied in New York and painted in the studio of John R. Smith. In 1850 he went abroad and visited many of the Continental cities, making numerous sketches and studies. Mr. Gifford was elected a member of the National Academy in 1854. In I860 he visited Switzerland, Italy, Greece, and Egypt, making many studies, from which he afterward painted some of his most charming pictures. He was "commended for excellence in landscape painting" at the Centenrial Exposition, 1876. Few artists could paint the sunset as could Gifford, and few could so well express the subtle moods of Nature as could he. He died in I88o.

There is a peculiar magnetism in Gifford's style of manipulation that attracts the eye, let the scene be ever so commonplace.-Art Journal, July, r876.

Varied in his powers, and sustained, free and finished in his methods, his pictures always manifest great elevation of thought and feeling. They are the interpretation of the profounder sentiments of nature, rather than of her superficial aspects.-Prof. WeIr. Report on Artat the Centennial Exposition The Rondout Kills. 
244. Matthew H. Jouett. (See No. 127.)

Portrait of Mr. R. S. Todd. Mrs. M. P. Logan, Louisville.

245. Joseph Lyman, Jr., New York. (See No. 236.)

Evening. Grady \& McKeever, New York. (\$250.)

246. A. T. Bricher, Southampton, L. I. (See No. 193.)

* On the Mill Stream, Byfield.

(Illustration, page xxxii).

$(\$ 400$.

247. Horace Wolcott Robbins, N. A., New York.

B. Mobile, Ala., I842. Pupil of James M. Hart, N. A., New York. First exhibited, in the National Academy, I860. Visited Jamaica with F. E. Church, N. A., in I865, immediately following which he went to Europe for three years, studying in Paris during the winters, and making sketching tours through France, Switzerland and elsewhere in the summer seasons. Elected National Academician, 1879. Member of the American Water-Color Society and the American Art Union.

* Landscape.

For sale.

248. Constant Mayer, A. N. A. (See No. 199.)

*An $I d y l$.

$(\$ 600$.

A sweetly poetic and refined picture, which Constant Mayer has about finished and will exhibit in a few days, is called "An Idyl." A golden-haired young girl of sixteen sits at sunset on the rocky border of a small stream, pulling to pieces a daisy to tell her fortune, repeating the test "he loves me, loves me not," reminding one of the beautiful "Marguerite." Below her, close to the pool, a handsome dog stands, looking wistfully up into the face of his mistress. In the back-ground are clumps and groves of trees, beginning to grow dim in the twilight, while the sky is a peculiar warm, greenish hue, as the golden tints of the twilight are melting into the blue.-Old New York Paper, 1879 .

The charm of this work lies not only in the vividness, fidelity, and naturalness of the study, but in the poetic suggestiveness of the scene-a trait admirably shown in other works by Mr. Mayer, but in few with more delicacy and subdued power.-Jewish Messenger, 1879 .

249. C. A. Platt, New York. (See No. 38.)

Fishing Boats, Gloucester, Mass.

(\$I 5O.)

250. J. R. Brevoort, N. A., New York. (See No. I70.) *A French Cottage-Savoy.

251. Charles T. Phelan, New York. (See No. 223.) Landscape and Sheep. T. A. Wilmurt, New York. 
252. J. C. Nicoll, A. N. A., New York.

B. New York, 1846. For three years was a pupil of M. F. H. De Haas, N. A. Elected Associate Member of the National Academy, 1880. One of the original members of the American Water-Color Society. Member of the New York Etching Club and of the American Art Union.

* York Beach, Maine.

(\$300.)

253. William Morgan, A. N. A., New York. (See No. 103.) * Coming from the Field.

A painting of wonderful strength and breadth; excellent in qualities, bright and rich in color, true to Nature, and charming in sentiment.

254. C. Maes, Brussels. Barnyard Fowls.

Mrs. C. F. Johnson, Louisville.

255. George M. Clark, New York. An Old Farm-House-Ecouen, France.

(\$200.)

Grady \& McKeever, New York.

256. H. Bolton Jones, N. A., New York.

B. Baltimore, Md., I848. Studied art in New York and went to France in 1876 . Remained four years abroad in study and travel. Elected National Academician, I883. Has been a regular contributor to National Academy of Design since 1874, and has also exhibited in Royal Academy, London, and the Salon, Paris. Member of the American Art Union, American Water-Color Society, and Society of American Artists.

Bolton Jones stands in the first rank of American landscape painters. His pictures contain all the detail that quality can possibly demand, and yet suffcient breadth to satisfy any but the most ultra impressionist. He paints pictures and effects that we all have seen, and have delighted in seeing, in Naturc. His pictures speak to us as poetically and as truthfully as Nature herself speaks.-Louisville Spectator.

* Through the Willows.

(Illustration, page xvi.)

An effect in early autumn; bright sky and excellent realization of distance. Trees carefully studied, and painted literally yet broadly.-National Academy Notes, 1884 .

257. Walter Satterlee, A. N. A., New York.

B. New York. Pupil of the National Academy of Design and of Edwin White, N. A., New York, and of Léon Bonnat, Paris. First exhibited, National Academy, I 868. Elected Associate Member of 
the Academy, 1878. Member of the American Water-Color Society and of the American Art Union.

* Two June Roses.

258. Charles Harry Eaton, New York.

B. near Akron, Ohio, I850. Studied Art without a master in Chicago. Exhibited for the first time in Chicago Exposition, I879. Came to New York in 188I and exhibited at National Academy of Design same year. Member of the American Art Union.

Landscape, Indian Summer.

$(\$ 200$.

259. Charles H. Miller, N. A., New York. (See No. 190.) * Sunset near Creedmoor, L. I.

26o. E. Wood Perry, N. A., New York. (See No. 92.) * Reading the Bible.

261. August Frederic Albrecht Schenck, Ecouen, France.

B. Glückstadt, 1828. Spent some time in business in England and - Portugal before he determined to become an artist. Then became a pupil of Cogniet. First exhibited, in the Salon, I855. Chevalier of the Orders of Christ of Portugal and of Isabella the Catholic. Medal at Philadelphia, i876. Schenck's pictures are found in most modern collections, and are very popular in England, Portugal, and America.

All the world to-day regards Schenck as one of our first animal painters. $\mathrm{He}$ is one of those originals, of a species not yet extinct, who prefer dogs to men, and find more sweetness in sheep than in women. With such fancies one leaves the city for the fields and has only to do with animals. Our artist has taken this part after having profoundly studied his fellow creatures. . . His animals' heads are portraits particularized with all the care which Cabanel, Dubufe, and Bonnat give to the human mask.-Paris Figaro, June 5, I878.

Sheep in a Snow Storm.

$$
\text { Gustav Reichard, New York. }
$$

262. Thomas Hill, San Francisco, Cal.

B. Birmingham, England, I 829. Taken by his family to America in I84I, to Taunton, Mass. Went to Boston in I844, and subsequently connected himself with decorating firms in that city and Philadelphia. In I854 entered Life class in Pennsylvania Academy of the Fine Arts, Philadelphia, and later studied for a time with Paui Mayerheim in Paris. Awarded medal and diploma at the Centennial Exposition. Member of the American Art Union. * Morning in the Yosemite. 
263. William M. Brown, Brooklyn, N. Y.

B. Troy, N. Y., 1827. First studied with A. B. Moore, of Troy. Painted portraits for a time, but in 1850 turned his attention to the study of landscape. In 1865 began painting fruit-pictures, in which he has made distinguished reputation. Member of the American Art Union.

* Fruit and Silver.

264. Henry De Beul.

Sheep.

Joseph E. Temple, Philadelphia.

$(\$ 275$.

265. William Hahn, San Francisco, Cal.

B. Saxony, Germany. Studied first in the Academy at Dresden and afterward at Düsseldorf. Came to America in $\mathbf{I} 87 \mathrm{I}$, and lived for a short time in Boston, afterward removing to San Francisco. His "Market Scene in San Francisco" was bought by Governor Stanford for $\$ 2,500$. Mr. Hahn has been awarded a number of medals, and his pictures command a ready sale.

Mexican Cattle Drivers.

$(\$ 600$.

266. R. W. Van Boskerck, New York. (See No. 225.)

Winter on the Harlem River, New York.

267. George Inness, N. A., New York. (See No. 212.)

Scene at Durham-An Idyl.

Fine in treatment, attractive in its tranquil harmony, is "An Idyl-Scene at Durham," the tender mood of a poetic fancy.-J. R. W. Hitchcock.The Inness Exhibition.

American Art Association, New York.

268. William Bradford, A. N. A., New York. (See No. 46.)

* Return of the Labrador Fishing Boats. (Illustration, page $\mathrm{xx}$.)

$(\$ 600$.

A sunset sky with purple clouds tipped with gold. A tall iceberg on the right, purple and green where in shadow, but with touches of sunlight along its upper points.

269. Arthur Quartley, A. N. A. (See No. 113.) Moonlight on the Sound.

R. J. Menefee, Louisville.

This is certainly one of the finest pictures Mr. Quartley has painted, and it is one of the finest expressions of moonlight that any one has painted. The sky at the left of the spectator is bright and luminous, while on the right the clouds have gathered, hiding the horizon and middle distance in a deep, mysterious darkness, out of which a vessel is coming into the foreground. There is room for the exercise of imagination in the contemplation of this picture, which is one that can be seen and enjoyed again and again. 


\section{Vergilio Tojetti, New York. (See No. I Io.) Richelieu and Julie.

\author{
George H. Moore, Louisville.
} (Illustration, page v.)

Cardinal Richelieu (b. I585; d. I642), whom Voltaire and history justly consider the true architect of the French monarchy and the great parent of French civilization, was Minister of State in France in the reign of King Louis XIII. A conspiracy which was formed against the King and Cardinal is made the subject of a drama by Bulwer, Lord Lytton, in the course of which, Julie de Mortemar, the ward of the Cardinal, becomes an object of the admiration of the King, who seeks to have her married to his favorite, Count Baradas, in order that he may pay attention to her without creating a scandal in the eyes of the Queen and Court. Richelieu, learning of this, and discovering that Julie loves the young Chevalier de Mauprat, who loves her in return, hastily sends for de Mauprat, and finding him a young man to his pleasing, has the pair married at once. When the king hears of this, he is greatly enraged, and under the royal seal promulgates an order proclaiming the marriage contrary to law, inasmuch as de Mauprat had, at an earlier time, been judged guilty of high treason, in having seized one of the royal towns while following under the Duc d'Orleans in the Languedoc revolt.

Soon afterward the King sends for Julie, and when she attends at the Louvre, reproaches her for the marriage, proclaims the bond unlawful and commands her not to leave her quarters in the palace. Iate in the night he goes to her apartment. Julie repulses him and then flies from the palace to Richelieu. She tells him all that has happened:

"There at night-alone-this night-all still-

He sought my presence-dared-thou read'st the heart,

Read mine!-I can not speak it!"

\section{Richelieu.}

"He a King,

You-woman; well-you yielded!"

$$
\begin{aligned}
& \text { Julie. } \\
& \text { "Cardinal! }
\end{aligned}
$$

Dare you say ' yielded ?'

Humbled and abashed

He from the chamber crept-this mighty luouis;

Crept like a baffled felon!-yielded! Ah!

More royalty in woman's honest heart

Than dwells within the crowned majesty

And sceptered anger of a hundred kings!

Yielded! - heavens! - yielded!"

\section{Richelieu.}

"To my breast-close-close !

The world would never need a Richelieu, if

Men, bearded, mailed men-the Lords of Earth-

Resisted flattery, falsehood, avarice, pride,

As this poor child with the dove's innocent scorn

Her sex's tempters, Vanity and Power!

He left you.-Well? 
The picture is an admirable portrayal of the interview between the Cardinal and Julie. The face of Richelieu is readily recognizable by one familiar with the numerous portraits of the Cardinal to be seen in Paris. Richelieu is seated in a high gothic chair in a splendid apartment hung with rich tapestries. Through the entrance, the rosy glow of the early morning light comes through the arches and touches the sides of slender gothic columns. Julie knecls beside the Cardinal, her right hand upon his shoulder, while his left hand rests upon her head. At the right of Richelieu is a table upon which is an open book, a skull, and a crucifix. A pale, gray, reflected light comes through a window-not shown in the picture-and illumines the interior. The Cardinal is attired in a dark garb bordered and banded with crimson; Julie wears a costume of blue and yellow satin richly embroidered with gold.

271. S. R. Gifford, N. A. (See No. 243.)

In the Catskills.

Morston Ream, New York.

$(\$ 400$.

272. R. W. Van Boskerck, New York. (See No. 225.) A New Jersey Landscape.

Morston Ream, New York.

$(\$ 100$.

273. J. Jay Barber, Columbus, O. (See No. 19.)

* Over the Hills.

One of the most interesting and attractive of Mr. Barber's recent works.

274. William M. Brown, New York. (See No. 263.)

* Fruit.

An exceedingly literal imitation of Nature, rich in decorative qualities.

275. William H. Lippincott, New York.

B. Philadelphia, Pa. Studied eight years in Paris, pupil of Leon Bonnat. First exhibited, Salon, Paris, 1876. Professor of Painting in the National Academy schools. Member of the American Art Union.

Trio Good Friends.

Exhibitcd in the Salon, Paris, in I880; afterward in the National Academy, New York, receiving high commendation from various critics.

276. Carl Weber, Philadelphia.

Pets of the Farm. Harrison EarL, Philadelphia.

277. J. J. Hammer, New York.

Studied abroad.

A Country Road. Grady \& M'Keever, New York.

$(\$ 400$. 
278. George A. M'Kinstry, Hudson, N. Y.

B. Hudson, N. Y., I855. Pupil of L. E. Wilmarth, N. A., J. II. Dolph, A. N. A., and the Art Students' League, New York. First exhibited, National Academy, 1877. Studied in Paris, I8S I.

On the Marne.

(Illustration, page $\mathrm{xxxix.)}$

$(\$ 300$.

The river Marnc joins the Seine near Paris. The Valley of the Marne, in which this view is found, is noted for its charming landscape cffects. This picture represents a cool, gray day in early summer-National Academy Notes, 1884 .

279. Charles Melville Dewey, New York.

B. at Lowville, N. Y., I851. Self taught. First exhibited, National Academy of Design, 1875. Member of the Society of American Artists.

Landscape, November.

(\$200.)

280. Henry P. Smith, New York.

B. Waterford, Conn., 1854. Went to New York, 1867. Self taught. Member of the American Water-Color Society and of the American Art Union.

Landscape.

George H. Moore, Louisville.

One of the most exquisite examples of Mr. Smith's work.

281. T. Addison Richards, N. A., New York.

B. London, 1820. Studied in the National Academy of Design, New York, 1843-1847. First exhibited, National Academy, I846. Elec:ed Academician, I85I. Secretary of the National Academy from 1852 to the present time. First Director of Cooper Unın School of Art for Women, 1858-1860. Professor of Art in the University of New York since 1867. Author of a number of Art Works.

His works all show that sure artistic sense of the elements of beauty which have heretofore given the artist his rank in the art production of the country. N. Y. Home Journal.

* On the Androscoggin.

(\$I 2O.)

282. Alice Barber, Philadelphia. (See No. 48.)

Discussing the Stitch.

$(\$ 200$.

283. Otto H. Bacher, Cleveland, O. (See No. 37.)

* A Shrine in St. Mark's, Venice. 
284. Henry P. Smith, New York. (See No. 280.) Along the River.

285. E. Williams, San Francisco, Cal. Flowers.

GEORGE H. MOORE, Louisviile.

286. Frederick W. Freer, New York.

B. Chicago, Ill. Studied in the Bavarian Royal Academy, Munich, and also in Paris. First exhibited, National Academy, IS8I. Member of the American Water-Color Society and of the American Art Union.

* Adagio.

A young woman seated at an organ, near a window. The reflected light, opposed to the direct light from the window, is expressed with fine effect.

287. Rhoda Holmes Nicholls, New York.

Studied abroad.

The Gondoliers' Shrine.

A bright, out-door study of one of the quaint "properties" of religious life about Venice.

288. E. L. Henry, N. A., New York. (See No. 160.) * In the Pasture

(\$200.)

289. J. H. Dolph, A. N. A., New York. (See No. 210.)

High Life.

Geo. H. Moore, Louisville.

One of the artist's very best pictures. Exhibited in the Salon, Paris, and in the National Academy New York.

290. Carl Weber, Philadelphia.

Near Fort Washington.

HARRISON EARL, Philadelphia.

291. Charles T. Phelan, New York. (See No. 223.)

Sheep, Evening.

No other man in Europe paints such Sheep as Jacque paints, yet in the Exposition Gallery there is now a small "Sheep" picture by Charles T. Phelan that not only looks like a Jacque but suggests that artist's very best work. It is fresh, artistic, and wonderfully true.-Courier-Journal, August 3, $\mathrm{I} 884$.

292. G. Ribes. (Spanish.)

A Musical Bar.

Dr. J. R. Leaming, New York.

293. J. G. Brown, N. A., New York. (See No. I57.)

A Clear Conscience. Morston Ream, New York. (\$500.) 
294. J. H. Dolph, A. N. A. (See No. 210.)

* A Playful Kitten.

$(\$ 100$.

Mr. Dolph has long had a reputation for painting kittens with a degrec of realism probably unequaled by any other living artist working in the same direction. $-N . Y$. Music and Drama.

An excellent study of a kitten, with bright, richly colored accessories painted with exquisite realism; the whole resulting in a picture of great brilliancy and fine decorative quality.

295. Frederick Dielman, N. A., New York.

B. I848. Studied in the Bavarian Royal Academy at Munich. One of the founders of the Society of American Artists. Member of the American Water-Color Society, the New York Etching Club, the Salmagundi Sketch Club, and the American Art Union. Elected member of the National Academy, I883.

... This artist, moreover, shows a rare reticence in the exercise of his technical skill ; . . . in this, and other slight characteristics, the truc artist is revealed; the master, not the slave, of form, color, and textural effect.Bayard Taylor, in New Fork Tribune, April 7, 1877.

* A New York Arab.

A most characteristic study of one of a large class of prospective $\mathrm{Ncw}$ York citizens, painted in a manner that strongly suggests some of the pictures by Murillo-notably those in the Old Pinakothek, in Munich.

296. J. W. Casilear, N. A., New York. (See No. 216.) *The Genesee Valley.

$(\$ 700$.

Excellent sky and fine effect of distance.

297. J. W. Woodwell, Pittsburgh, Pa. (See No. 27.)

The Connecticut Shore.

J. J. Gillespie \& Co., Pittsburgh, Pa.

298. William Wall, Pittsburgh, Pa.

View on the Monongahela.

J. J. Gillespie \& Co., Pitisburgh, Pa. \$300.)

299. Leon Delachaux, Philadelphia.

An Important Secret. Harrison Eari, Philadelphia.

(\$200.)

300. Hamilton Hamilton, New York.

B. 1847. Studied in France and England. First exhibited at the National Academy in I88I. Member of the American WaterColor Society and the American Art Union.

* Turitight. 
301. A. Corelli, Rome.

Medals at Rome, I876, I877, and 1880.

The Golden Opportunity.

This is the artist's most important work.-Haseltine Catalogue, 1883.

Joseph E. Temple, Philadelphia. (\$I,000.)

302. Annie Morgan, New York.

B. Brooklyn, N. Y. Pupil of her father, William Morgan, A. N. A., and of the National Academy, New York. Instructor in the Ladies' Art Associations of New York and Brooklyn.

$A$ Study of Fruit.

Broadly and suggestively painted, exceedingly rich in color and brilliant in effect, Miss Morgan's fruit study contains much to delight a connoisseur and to instruct a student of art.-Louisville Courier-Journal.

303. George Hetzel, Pittsburgh, Pa. (See No. 7.) A Landscape Study.

J. J. Gillespie \& Co., Pittsburgh, Pa.

(\$1 50.)

304. Rembrandt Van Ryn.

B. at Leyden, 1607. D. 1669. Pupil of J. J. Van Swanenburg, and possibly of Pieter Lastmann and Jacob Pinas, but so original in his own manner, that the influence of none of these masters can be seen in his works. At twenty-two years of age, he established himself at Amsterdam, where he resided until his death. Rembrandt was one of the greatest portrait painters that ever lived. The effects of light and shade in his pictures, and the marvelous richness of his coloring, are the admiration of the world to-day.

The Lesson in Anatomy.

Supposed to be the original study for the great picture in the Royal Gallery at the Hague. Note the experimental sketches along the right hand edge of the canvas.

R. H. Wildberger, Memphis, Tenn.

305. W. S. Macy, New York. (See No. 240.)

Forest Scene in Winter.

These lines appear on the tablet of the picture:

"Among the beautiful pictures

That hang on memory's wall,

Is one of a dim old forest

That seemeth the best of all."

306. W. H. Snyder, New York.

Member of the American Art Union.

* Apples and Cider.

(\$140.) 
307. Matthew H. Jouett. (See No. 127.)

Portrait of the Artist.

R. J. Menefee, Louisville.

308. M. Mencci, Florence.

Fruit.

Mrs. J. M. REeD, Louisville.

309. Edward Gay, New York. (See No. 233.)

* Out in the Hayfield.

(\$200.)

A very bright, luminous example of the artist's best work.

310. Rosa Schweninger, Vienna.

No authorities at hand contain any definite information concerning this artist, but her talent is well recognized. She was represented at the Centennial Exposition by a picture entitled "A Neapolitan." An Old Antiquary. Philip Gaertner, Louisville.

An old man is looking through a small lens at an antique statuette which he holds in his hand. The table before him is covered with bric-a-brac, jewels, and various antique articles, all reproduced with marvelous fidelity to nature. The expression in the man's face is a wonderful study.-Louisville CourierJournal, August I9, I884.

3II. Carl L. Brandt, N. A., New York, N. Y., and Savannah, Ga. Studied in Düsseldorf, Munich, Florence, and Paris. First exhibited in the National Academy. Elected member of the Academy, 1872. Director of the Telfair Academy of Arts and Sciences, Savannah, Georgia. Member of the American Art Union.

Portrait of a Lady.

The ARTist.

As carefully painted as any thing Meissonier has done. The quality of flesh is admirably rendered, and without the loss of any character from the face. The black silk dress and the plush drapery in the background are extremely faithful representations.

312. Charles F. Ulrich, A. N. A., New York.

B. New York, 1858. Pupil of Loefftz and Lindenschmidt, in Munich. First exhibited, Düsseldorf, 1880; National Academy, 1882. Elected Associate member of the National Academy, I883. Awarded the Clark Prize for " the best American figure composition painted in the United States by an American citizen not a member of the Academy, and shown in an Academy exhibition," in the Academy exhibition of this year.

$A$ German Peasant.

$(\$ 150$.

3r3. William M. Harnett, Philadelphia.

B. Philadelphia, 185I. Pupil of the National Academy of Design, New York. Went abroad in 1880 . Now studying in Munich. 
Paints still life as realistically as does Blaise Desgoffe, of Paris, whose reputation in that line is international.

Still Life.

314. R. M. Shurtleff, A. N. A., New York.

B. Rindge, N. H. Studied at the Lowell Institute, Boston, and at the National Academy of Design, New York. First exhibited, National Academy, 1872. Elected Associate member of the National Academy, I88I. Member of the American Water-Color Society and of the American Art Union.

Mr. Shurtleff is one of the most earnest and conscientious of our painters and his pictures are not only truthful representions of Nature, but they suggest to us those sentiments which Nature herself suggests.

*Mt. Porter.

\section{I5. G. Voorhes.}

Normandy Cattle.

Mrs. C. F. Johnson, Louisville.

316. Matthew H. Jouett. (See No. 127.)

Portrait of the Artist's Wifc. $\quad$ R. J. Menefee, Louisville.

317. Thomas B. Craig, Philadelphia, Pa.

Member of the American Art Union.

* The Home of The Fish-Hawk.

$(\$ 325$.

An exceedingly bright, well-painted landscape.

3I8. Frederick A. Bridgman, N. A., Paris.

B. Tuskegee, Ala., 1847. Pupil of the Brooklyn Art Association, and studied later in Paris under Gérome, whose favorite pupil he became. First exhibited in the Salon, Paris, in $186 r$, and in the National Academy, New York, in 187 r. Received a medal for his picture in the Salon of 1877 , and was awarded another medal and made a Chevalier of the Legion of Honor in 1878 . Was elected a member of the National Academy, New York, I88I.

Scene in Algiers.

N. SARony, New York.

$(\$ 200$.

3rg. A. G. Heaton, Paris.

B. United States.

A Cavalier.

Grady \& McKeever, New York. (\$150.)

320. M. De Forest Bolmer, New York. (See No. 205.)

* Early Morning. 
321. Frank L. Kirkpatrick, Philadelphia, Pa.

B. Philadelphia, 1853. Pupil of the Bavarian Royal Academy, of Professors Strachuber, Ferdinand Barth, and Anton Seitz, Munich, First exhibited, Pennsylvania Academy of Fine Arts, Philadelphia. 1880.

\section{Benvenuto Cellini Unveiling his Statue of Perseus with the Head of Medusa. \\ George H. Moore, Louisville.}

While this scene is purely ideal-the circumstance of the unveiling of the statue having occurred with very different surroundings-the composition is so admirable, and the coloring so rich and glowing, that we may even fecl thankful to Mr. Kirkpatrick for treating the subject from a poetical rather than a literally truthful standpoint. There is something very Turneresque in the coloring of this picture, and the representation of the rare, costly marbles, the superb tapestries, and all the gorgeous accessories is wonderfully effective. The figures, too, are well grouped, well drawn, and are full of character.-Louisville Courier-Journal.

Benvenuto Cellini was a celebrated sculptor who lived in Florence (b. I500; d. I570.) His statue of Perseus with the head of Medusa (in bronze) was modeled at the instance of Cosimo de Medici, and now stands in the Loggia dei Lanzi in Florence. It was one of Cellini's greatest works.

Medusa was a beautiful maiden, who, having with Poseidon profaned the temple of Athena, that goddess caused the hairs of her head to become snakes, while to her face was given the power of turning every thing it looked upon to stone. Perseus, when he reached manhood, resolved to slay Medusa, and received assistance to that end from the Grææ-three strange beings having in common one eye and one tooth. They provided him with winged sandals, a magic wallet, and the helmet of Hades, which rendered the wearer invisible. Hermes added a curved sword, and Athena gave him a mirror. Perseus when he came near Medusa, looked at her figure in the mirror-by which means he preserved himself from petrifaction-and then, making himself invisible, was enabled to slay her. Perseus, after performing various miraculous fcats in which he employed Medusa's head to advantage, presented it to Athena, who fixed it upon her breast-plate.

322. M. F. H. De Haas, N. A., New York. (See No. 8.) $_{3}$ * Mt. Argueil Castle, Isle of Jersey.

A picturesque scene with glowing sunset effect. Painted by the artist for this exhibition,

323. Henry A. Loop, N. A., New York.

B. Hillsdale, N. Y., I831. Pupil of Henry Peters Gray, New York, and Thomas Couture, Paris; afterward studying in Rome, Venice, and Florence. First exhibited, National Academy, I $\$_{53}$. Elected member of the Academy, I86r. Member of the American Art Union.

*The Awakening. 
A mother in light attire, as if prepared for a bath, has apparently fallen asleep on the bank of a quiet stream running through the forest. The pretty child, missing the companionship of its mother, playfully touches her face with a clover-leaf, bringing the suggestion of a smile preceding the "awakening." Both figures possess that exquisite grace and refinement so characteristic of Mr. Loop's work.-National Academy Notes, I883.

324. M. F. H. De Haas, N. A., New York. (See No. 83.) * Moonlight.

Another characteristic and very excellent example of Mr. De Haas's work. Also exhibited now for the first time.

325. J. H. Witt, New York. (See No. I34.) Outdoor Luxury. (Illustration, page xii.)

Morston REAM, New York.

A group from a picnic party resting in the shade near the border of a stream, on a hot afternoon.

326. Percy Moran, New York. (See No. 23.) An Old-Time Melody.

Thomas B. Clarke, New York. (Illustration, page xxix.)

Another picture full of sentiment is Percy Moran's "An Old-time Melody." An attractive young woman in the costume of the early part of the century sits at a harpsichord in front of a window. The picture is a symphony, and the white gown of the girl, the white curtains at the window, and the tearoses on the harpsichord, make a charming effect in the soft light that shines through the window.-Louisville Courier-Journal.

327. Harry Chase, A. N. A., New York. (See No. 214.) Return of the Trazelers.

R. J. Menefee, Louisville.

A view at Scheviningen, on the coast of Holland, where the population depends principally upon herring fishing for existence. A group of fishermen and women, in quaint, characteristic costume, are standing under the side of a stranded boat, awaiting the landing of several boats coming across the water, whose cargoes they will assist in discharging. The sky is luminous, and the water is very realistically painted.

328. Xanthus Smith, Philadelphia. (See No. 102.) An Old Ruin on the Pennypack.

329. Samuel Colman, N. A, New York. (See No. Ioo.) Guadalquiver. Grady \& McKeever, New York.

$(\$ 500$.

330. Henri Coroenne, Paris.

B. Valenciennes. Pupil of Picot and Abel de Pujol. Medal at Philadelphia, where he exhibited "The Salutation."

The Salutation.

Joseph W. Wayne, Cincinnati. 
33r. Carl C. Brenner, Louisville. (See No.7r.)

* A Winter Afternoon.

A careful study of a beech-woods in winter; snow on the ground and a bright sunset glow in the sky.

332. J. G. Brown, N. A., New York. ('See No. 157.)

"Let's Make Up." Morston Ream, New York. (\$400.)

One of the most pleasing pictures Mr. Brown has painted, and one of the best from a technical standpoint. Two bootblacks have had a misunderstanding, and one of them desires to "make up." The other is holding aloof. The studies in expression are very admirable.

333. George Sharples, Liverpool, England.

B. Liverpool. For many years was a general commission merchant and cotton-broker in Cincinnati, devoting himself to Art in his leisure moments. Having fallen heir to a large estate, he returned to Liverpool, where he now pursues Art in a leisurely way.

A Misty Morning. $\quad$ R. J. Menefee, Louisville.

A peculiarly attractive picture, with a wonderfully fine effect of light breaking through the fog.

334. Johannes A. Oertel, A. N. A., Washington, D.C. (See No.36.) * Elijah on Mt. Horeb.

And Elijah arose and did eat and drink, and went in the strength of that meat forty days and forty nights unto Horeb, the mount of God.-I Kings, xix, 8.

Mr. Oertel's conception of the Prophet is striking and satisfactory. We might almost recognize him without the information of the catalogue. The picture is painted with rare fidelity to nature, and in its color and tone might almost be mistaken for a work of one of the best of the old masters.

335. William M. Harnett, Philadelphia. (See No.3r3.)

A Library Table. Geo. H. Moore, Louisville.

336. J. Jay Barber, Columbus, O. (See No. 19.)

* In Meadows Green.

337. F. K. M. Rehn, New York. (See No. 65.)

* A Calm Evening.

$(\$ 75$.

Another picture by Rehn, "A Calm Evening," will be one of the favorites of the collection. It is a small picture, very suggestive of its title. There is a charmingly tender light in the sky, the distance is excellently expressed and throughout, in qualities and harmonies, the picture is very realistic.Louisville Courier-Journal, August I9, I834. 
338. Compo Tosta. (Italian.)

Tired Out.

Geo. H. Moore, Louisville.

Charming in sentiment and exquisite in color and harmony.

339. A. H. Wyant, N. A., New York. (See No. Io9.)

* Forenoon, Adirondacks.

$(\$ 1,500$.

(Illustration, page ix.)

A morning effect in summer, looking over a wild, rugged, open piece of country. The value of the painting is in its superb effects of light and distance, and its excellent technique, which, while broad, is definite, and while suggestive is also realistic.-National Academy Notes, 1884 .

340. William T. Richards, A. N. A., Philadelphia. (See No. 54.) * Morning at Brigantine Beach, $N$. J. 


\section{ख્iftures int the (East (Sallern.}

341. J. L. Stewart, Paris.

B. Philadelphia. Pupil of Fortuny, of Madrazo, and of Gerome. Has received several medals.

The Proposal. A. D. Vorce \& Co., Hartford, Conn. (\$1,200.)

342. Hermann Fuechse1, New York. (See No. 201.)

* The Watering Place.

343. T. J. Fisher, Washingto n, D. C. A Stevedore. Major W. H. Thomas, Louisville.

344. Miss S. F. Benney, Pittsburgh, Pa.

A Bunch of Peonies. J. J. Gillespie, Pittsburgh, Pa.

345. Carl L. Brandt, N. A., New York and Savannah. (See No. 3 I I.) Portrait of General Henry $R$. Jackson, President of the Georgia Historical Society.

A most exquisite piece of flesh representation united with excellent expression of the character of the subject.

346. James Hart, N. A., New York. (See No. 22.)

Thou art so Near and yet so Far.

(\$400.)

347. Georges Haquette, Paris.

B. Paris. Pupil of Jean François Millet and Alexandre Cabanel. Medal, I88o.

The Passage.

Reichard \& Co., New York. (\$60o.)

348. Julian Rix, Paterson, N. J.

Member of the American Art Union.

*A Jersey Hay-Rick.

(\$250.)

A bright picture of excellent quality and atmospheric effect.-Art Union, January, 1884 . 
349. Nicola Marschall, Louisville.

B. St. Wendel, Rhine, Prussia, 1829. Came to America, to New Orleans, I 849 , to go into the tobacco business. Became devoted to Art and painted portraits with considerable success in the rich cotton regions of Alabama, making his headquarters for a time at Mobile. From I857 to 1859 was in Europe, where he studied under Hofmaler Bernhard, Court Painter at Munich, and afterward studied from the works of the old masters in Italy and Paris. Came to Louisvilie, 1873 .

Portrait of General $N$. B. Forest, C. S. A.

350. Horatio S. Stevenson, Alleghany City, Pa.

B. New Castle, Pa. Studied at the National Academy of Design, New York, 1877-78.

Hydrangeas. J. J. Gillespie, Pittsburgh, Pa.

35I. E. Wood Perry, N. A., New York. (See No. 92.)

*The Story Book.

(Illustration, page xxvii.)

A picture of home-life, painted in a careful, realistic manner. Rich in color, charming in sentiment.

352. Carleton Wiggins, Brooklyn, N. Y.

B. Turners, N. Y., I848. Pupil of the National Academy of Design, New York. First exhibited, National Academy, I870; Paris Salon, I88I. Studied in France in I880-8I. Member of the American Art Union.

* Come, Bossy.

353. C. R. Leslie, R. A. (See No. I6.)

Isaac Blessing his son Jacob. Dr. J. R. Leaming, New York.

Illustrating the deception practiced upon Isaac by Rebekah and her favorite son.

And Isaac said unto Jacob, "Come near, I pray thee, that I may feel thee, my son, whether thou be my very son Esau or not." And Jacob went near unto Isaac his father; and he felt him. ... And he said, "Art thou my very son, Esau ?" And he said, "I am." And he came near, and kissed him : . . . and blessed him.-Genesis xxvii.

354. M. F. H. De Haas, N. A., New York. (See No. 83.) Off the Isles of Shoals. Major C. J. F. Allen, Louisville.

355. Carl C. Brenner, Louisville. (See No. 7I.)

* A Winter Morning in the Forest. 
One of the best of Mr. Brenner's characteristic Beechwoods studies. A picture the spectator feels he can "walk into," so real does the scenc appear.

356. Marechal.

Portrait of the Rev. Dr. Stuart Robinson.

Col. Bennett H. Young, Louisville.

\section{Bernard Cornelius Koekkoek.}

B. Middelburg, Holland, r8o3. Pupil of Schelfhout and Van Os. Chevalier of the Order of the Lion of the Netherlands, and of the Order of Leopold, of Belgium. Medals awarded at Paris, Amsterdam, and the Hague. Member of the Academies of Rotterdam and St. Petersburg, and of the Society of Arts, of London. "The landscapes of this artist are much esteemed." (CLEMENT \& IIUtTon.) He established a Drawing Academy at Cleves, and published a volume of his "Souvenirs and Communications" in I850. D. r\$62.

A Dutch Landscape. Dr. James R. LEaming, New York.

358. Constant Mayer. (See No. 199.) Evangeline.

George H. Moore, Louisville.

Half way down to the shore, Evangeline waited in silence,

Not overcome with grief, but strong in the hour of afliction.

Evangeline was the daughter of Benedict Bellefontaine, the richest farmer of Acadia (now Nova Scotia). At the age of seventeen she was legally betrothed to Gabriel, son of Basil, the blacksmith, but the next day all the colony was exiled by the order of George II, and their houses, cattle, and lands were confiscated. Gabriel and Evangeline were parted, and then began the troubles of her life. She wandered from place to place to find her betrothed. Basil had settled in Louisiana, but when Evangeline reached the place, Gabriel had just gone. She then went to the prairies, to Michigan, and so on, but at every place she was just too late to catch him. At length, grown old in this hopeless search, she went to Philadelphia and became a Sister of Mercy. The plague broke out in the city, and, as she visited the almshouse, she saw an old man smitten down with the pestilence. It was Gabriel. He tried to whisper her name, but death closed his lips. He was buried, and Evangeline lies beside him in the grave.-BREwER.

Of the numerous painters of Evangeline, Mr. Mayer has succeeded best of all in realizing the character of the maiden of Longfellow's charming pocm. Before beginning this superb creation, Mr. Mayer visited Normandy, where the costume to-day is nearly the same as that worn by the French emigrants to Nova Scotia, and made studies of cxamples bclonging to the period of the poem, thus securing historical accuracy.

The period is when the pcasants of Arcadia are being driven from their homes; and Evangeline, scated on a rock at twilight, on the shore of the Basin of Minas, is awaiting the arrival of her father, her friend the priest, and her lover Gabriel. Further down on the road from Grand Pré, in the half light 
near the shore, groups of disconsolate women are seen, seated or standing, mourning the land they are about to leave. The exquisitely toned, slightly greenish sky, with the last lights of the sun fading away down beyond the hills, across the water to the right, and reflected in it, softly illumines the figure with a rosy tinge and empurples the shadows along the shore. The young girl, weary with waiting, looks with pathetic eyes upward, as if her mind sought to search into the future or to invoke the beneficence of heaven. The face and attitude of Evangeline indicate the mood of the moment, before the incidents have occurred which raise her sorrow to the highest point, and introduce her to that path of immitigable woe which she is to tread through life. The artist has kept in mind, however, that at this stage of her experience, notwithstanding the halo of poesy that Longfellow has thrown around her, the girl is still a peasant, and also that shadows born of profound and prolonged grief-such as are depicted so strongly in Faed's picture-are out of place in so fresh and virginal a countenance.

359. Irving $\mathrm{R}$. Wiles, New York.

B. Utica, N. Y., I86r. Pupil of his father, Lemuel M. Wiles (Director of the College of Fine Arts of Ingham University, LeRoy, N. Y.), of Ingham Univesity and of the Art Students' League, New York. First exhibited, National Academy, I88r. At present studying in Paris.

A Scotch Lassic.

R. J. Menefee, Louisville.

36o. Charlotte B. Coman, New York.

B. Waterville, N. Y. Pupil of J. R. Brevoort, N. A., New York. For a number of years she lived in Paris, studying the works of Corot, Daubigney, and other artists of the French school. Her landscapes often suggest the manner of Corot. Miss Coman paints many of her most pleasing pictures from studies made in Holland. Member of the American Art Union.

* A View near Dordrecht, Holland.

36r. Paul Burmeister, Munich.

Pupil of Frederich Kaulbach. Medals, I881, r884.

The Feast. $\quad$ A. D. Vorce \& Co., Hartford, Conn.

(\$300.)

362. Harry Chase, A. N. A., New York. (See No. 214.)

*Venetian Fishing-Boats.

Not a usual subject with Mr. Chase, but painted in his usual excellent manner.

363. Harry Chase, A. N. A., New York. (See No. 214.) * The Battery Park, New York. (Illustration, page xxiii.) 
Harry Chase's "Battery Park, New York," is a painting that takes one out of doors and makes him feel the wind and chill of an April day. For atmospheric quality and the expression of motion in the sky and water, the picture is remarkable; morcover, it has a value as a clearly recognizable portrait of an interesting locality.-The Art Union, April, 1884.

364. T. L. Smith, A. N. A., New York. (See No. 55.) *A Blackberry Girl.

365. E. Anders, Düsseldorf.

At her Devotions.

From the Düsseldorf Mahlkasten Gallery of Beautiful Women.

N. A. Frankel, Louisville.

366. Henry P. Smith, New York. (See No. 280.) Mid-Ocean.

Morston Ream, New York.

(\$200.)

367. Worthington Whittredge, N. A., New York.

B. Springfield, Ohio, r820. First studied art in Cincinnati, Ohio. Studied in Paris, I849, and afterward in Düsseldorf, under Andreas Achenbach and Lessing. Spent some time in Holland, studied in Belgium under Robbe, and for five years lived in Rome. First exhibited, National Academy, r845. Elected National Academician, I860. Was President of the National Academy, I875-76. Member of the American Art Union.

*A Pool in the Woods.

(\$500.)

Conscientiously devoted to his art, for manly fidelity to the simple verity of nature no one of our painters is more consistently distinguished than Worthington Whittredge.-TUCKERMAN.

His style evinces a subtle sympathy with the suggestive and evanescent qualities of the landscape.-PROF. WEIr.

368. Paul Burmeister, Munich. (See No. 36r.) Recreation.

A. D. Vorce \& Co., Hartford, Conn.

$(\$ 300$.

369. William Bliss Baker, New York. (See No. I98.) A Lowland Pasture, Morning.

One of the freshest, brightest impressions of Nature to be found in the gallery.

370. Thomas Hovenden, N. A., Plymouth Meeting, Pa.

B. Dunmanway, Ireland, I840. Studied in the Government Art School, Cork. Came to America in 1863 , and was a pupil of the evening classes at the National Academy of Design, New Tork. $\mathrm{He}$ devoted only leisure hours to painting until i $S_{74}$, when he con- 
cluded to follow art as a profession. Studied in France from $\mathbf{1} 874$ to 1880 ; pupil of l'École des Beaux Arts. .Elected National Academician, 1882. Member of the American Art Union. * Old Friends.

Broadly painted, full of character and very realistic.

37I. H. Bolton Jones, N. A., New York. (See No. 256.) Breaking Flax.

R. J. Menefee, Louisville.

For atmospheric effect, excellent qualities and exquisite sentiment, $\mathrm{Mr}$. Jones has painted nothing finer than this.

372. Wilson, Washington, D. C.

Portrait of Abraham Lincoln, Sixteenth President of the United States. Mrs. Joshua F. Speed, Louisville.

This portrait Mr. Lincoln had painted by Wilson only a short time before his assassination, to give to his friend, Joshua F. Speed. It did not reach Mr. Speed until after the President's death, and is supposed to be the last picture for which Mr. Lincoln sat.

373. Henry P. Smith, New York. (See No. 28o.) The Coast of Cornwall, England.

A. D. Vorce \& Co., Hartford, Conn.

$(\$ 350$.

A picture that might excusably be mistaken for an Andreas Achenbach, from the manner in which it is painted, yet not lacking in the individual qualities of Mr. Smith.

374. Benoni Irwin, A. N. A., New York. (See No. 79.) Portrait of Edward Muybridge.

Edward Muybridge was the first to photograph animals in mction, by the instantaneous process. This is a most excellent portrait of $\mathrm{Mr}$. Muybridge, and is one of Mr. Irwin's best works. In character and quality it has not been surpassed by any portrait painted in America.

375. Miss C. W. Conant, Brooklyn, N. Y.

Studied several years abroad. Member of the American Art Union.

* Afternoon Tea.

(Illustration, page xiii.)

376. Thomas Hovenden, N. A., Plymouth Meeting, Pa. (See No. 370.)

A Vendean Soldier.

377. Worthington Whittredge, N. A., New York. (See No. 367.) * An Old House by the Sea, Rhode Island.

A picture full of sunshine, with excellent atmosphere and distance. 
378. Mary Kollock, New York.

B. Norfolk, Va. Went to New York, I866. Pupil of A. H. Wyant, N. A. First exhibited, National Academy, I868. Member of the American Art Union.

* Gathering Wild Flowers.

(Illustration, page xviii.)

$(\$ 500$.

A view in Ulster County, N. Y. Morning effect late in the summer, with faint sunshine struggling through the clouds. Persons gathering flowers in foreground.

379. M. Leisser.

Making Sail. J. J. Gillespie \& Co., Pittsburgh, Pa. (\$250.)

380. Joseph W. Woodwell, Pittsburgh, Pa. (See No. 27.) A Light-House.

J. J. Gillespie \& Co., Pittsburgh, Pa.

381. G. H. McCord, A. N. A., New York. (See No. 206.) The Bon Secours Market, Montreal. (Illustration, page xxxiii.)

A view of the old Market and church facing the quay on the St. Lawrence, Montreal, on a moonlight evening in winter.

The American Art Association, New York. (\$300.)

382. Francis A. Silva, New York.

B. New York City, I835. Mr. Silva inherited his taste for Art from his grandfather, Colonel Francis Jean, of the French army, who, exiled during the first Revolution, went to Lisbon, devoted himself to his brush, and became Painter to the Spanish Court. Young Silva, whose father opposed his studying Art, after trying several trades, was apprenticed to a sign-painter in New York, where he remained until the outbreak of the rebellion, in which he served as an officer until its close. In I868, began his professional career as an artist, though he exhibited a picture in the National Academy the year preceding. Entirely self-taught. Member of the American Water-Color Society.

Near Point Judith, R. I.

(\$400.)

(Illustration, page $\mathrm{xxxviii.)}$

383. Francis Antoine Piotrowski, Paris.

B. Varsovie, Poland. Pupil of Gerson and Matejko.

Soldiers Waiting at the Ferry. 
384. P. V. Berry.

Landscape in Surrey, England.

Grady \& M'Keever, New York.

(\$150.)

385. Eugene Benson, A. N. A., Rome.

B. Hyde Park, on the Hudson, N. Y., I839. Began his studies at the National Academy, New York, and in the studio of J. H. Wright, portrait-painter. Later studied from the pictures at the Louvre, Paris, and from the works of the old masters in Venice. His professional life has been spent in New York, Paris, Venice, Rome, and in travel in Egypt, Syria, etc. Elected Associate member of the National Academy, I862.

Peasants of Cadore. (Titian's birth-place.)

R. J. Menefee, Louisville.

This picture was painted expressly for Mr. Menefee, in Rome. It represents a blind woman led by a little girl, with a sky and background strongly suggestive of the older Italian painters.

386. Burr H. Nicholls, New York. (See No. 176.) A Fruit-Seller, Brittany.

(\$100.)

387. Prof. G. Castagnola, Florence.

$A$ Mendicant Friar.

Mrs. J. M. ReED, Louisville.

388. Francis J. Murphy, New York.

B. Oswego, N. Y., I853. Self-taught. First exhibited, National Academy of Design, 1876. Member of the Society of American Artists and the American Water-Color Society.

Landscape.

389. J. M. Tracy, Greenwich, Conn. (See No. I48.)

Portrait of a Dog. Mr. P. Wooldridge, Louisville.

390. Homer Martin, N. A., New York.

B. Albany, N. Y. Studied for a few weeks with William Hart, N. A.; otherwise self-taught. Elected member of the National Academy, 1875. Member of the Society of American Artists.

Landscape.

391. H. Bolton Jones, N. A., New York. (See No. 256.)

On Herring Run, near Baltimore, $M d$.

ReIChard \& Co., New York. (\$I, 000.) 
An autumnal landscape; a tangled woodland with a road passing through it, across the stream, which flows from the foreground. There is a fine effect of distance, and a bright, luminous sky, which is reflected in the stream with the shadows of the trees. Mr. Jones has done his best work in this picture, which is one of the finest American landscapes that has been painted.

392. Victor Nehlig, N. A.

B. Paris, France, I830. Studied Art in his native city under Cogniet and Abel de Pujol. Came to America in 1850 , and opened a studio in New York. Elected a member of the National Academy in 1870. At present living abroad.

\section{Scenes in the Life of Daniel Boone. R. J. Menefee, Louisville.}

Mr. Nehlig hoped to obtain a commission from the State to paint a series of historical pictures for the Capitol, at Frankfort, and it was a greater misfortune to the State than to himself that this commission was not given. The design which he exhibited to the legislature was purchased by Mr. Menefee. It is in panels, with one large central painting and five side pieces, with some of the spaces decorated with monochrome drawings of Indian trophies. The artist had immersed himself in the study of the early days of Kentucky, and in this work reproduced not only the spirit of the times, but was historically accurate in everv costume and detail. The central painting represents Daniel Boone and his companions viewing the outspread plains of Kentucky, fertile and full of promise, below them, from a table-rock of one of the Alleghanies. The group of men is at rest yet full of animation. They are sturdy forms; boldness and vigor speak from every lineament. The smaller side-pieces are exquisite, and all represent historical incidents. In one, Daniel Boone encounters two Indians. His son lies at his feet, stricken down in the conflict; the Indian, who was in the act of rushing upon them, is struck down by Boone, who has drawn his knife for a nearer combat. The situation is very dramatic. The dark, tangled woods, with somber coloring, are in fine tone and ketping with the moment, and the attitude of the falling Indian is drawn with such power that his expiring yell almost startles the imagination. Below this is an Indian village fired by the whites. It would seem almost impossible for an artist, foreign to Kentucky, to so wonderfully reproduce an Indian summer and such an atmosphere as envelopes the little picture. This scene is also dramatic but more so by way of suggestion. The stealth of the approaching enemy, the terror of the flying Indians, and the beautiful calm, which always seems to settle down like an eternal peace in Indian summer, are put on canvas with a poet's sense of beauty and an artist's mastery of execution. The companion piece of this is an Indian attack on a block-house. The local coloring and historical accuracy of this must also be commended. The trees are deadened about the clearing, to afford no unperceived means of approach by the enemy, and the dry brush and bare limbs of the trees are in keeping with the idea of the scene, as well as a truthful incident of such places of defense. This little scene was painted over a great nuany times by the artist. He was delighted when the purchaser expressed his admiration of the sketch of the attack on the block-house, and exclaimed, in his impulsive French way: "You enchant me! there are three other block-houses under that one." Below the largest picture (the first view of Kentucky), is the incident of the capture by Indians of three children. The canoe in which they are is drawn to the shore by a stalwart Indian. The smallest give signals with a white cloth to the opposite shore, to attract the attention of friends. The minutest description of these six small pictures on one canvas could not con- 
vey a proper conception of their great merit. Nehlig is a poet. $\mathrm{He}$ has reproduced the romance of the early days of Kentucky as effectually as it may be done on canvas. Will T. Price, in The Age, April 5, I870.

393. Henry Alexander, New York.

B. San Francisco, Cal., I860. Spent seven years in Munich under Loeffts and Lindenschmidt. First exhibited, Munich exhibition, I879. Returned to America in 1883 .

Searching the Truth.

(\$200.)

394. Jasper F. Cropsey, N. A., New York.

B. Staten Island, I823. Studied architecture in New York for five years, and then turned his attention to landscape painting. Elected a member of the National Academy, I85I. Spent three years in Italy, and lived in Lonclon from 1857 to 1863 . Member of the American Water-Color Society and of the American Art Union.

Cropsey's painting is full of points that are new without being entirely foreign or strange to the European eye. It takes the ordinary observer into another sphere and region, while its execution will bear any amount of technical criticism.-London Times, 1862.

Autumn on the Ramapo.

One of Mr. Cropsey's most brilliant autumnal landscapes.

395. George Sharples, Liverpool, England. (See No. 333.) Bank Lick. (A stream near Covington, $K y$.)

A most charming landscape. Mr. Price has thus written of it in The Age: "The foreground is the rocky bed of a creek; broad and broken ledges of rock, over which flows a scattering stream, collected, near the spectator, into a wide and shaded pool. The banks recede in the near perspective; a willow tree droops over and kisses the clear water; there are woods to the right and left, and the background, in the sunnier and more cheerful hue of day, is expansive, fresh and inviting, with a suggestion of distance. The picture has great depth of atmosphere, and the management of light and shadow is admirable. It is a fixing on canvas of one of the transient glories of Nature."

R. J. Menefee, Louisville.

396. Leon Delachaux, Philadelphia.

A Difficult Problem. Harrison Earl, Philadelphia.

397. Constant Mayer, A. N. A., New York. (See No. 199.) * The Song of the Shirt.

Constant Mayer has just finished a life-size, nearly full-length figure, illustrating one of Hood's greatest and saddest poems. A woman, still young in years,

With fingers weary and worn,

With eyelids heavy and red,

Sits at her old, bare, pine table, finishing the garments which give her, as the fruit of unceasing toil,

A bed of straw,

A crust of bread-and rags;

That shattered roof, the naked floor,

A table, a broken chair. 
The burned-out candle shows that she has been sitting all night at her work; the gray dawn is seen through the narrow window, creeping over the roofs of London; the smoke is just rising from the chimneys, and every thing around seems preparing for the next day's toil before hers of yesterday is finished. Her eyes are dark-ringed and sunken, and look vacantly forward, longing,

But for one short hour,

A respite however brief;

There being in that dreary life, from day to day,

No blessed leisure for love or hope,

But only time for grief!

A little weeping would ease the heart;

But in their briny bed

The tears must stop, for every drop

Hinders needle and thread.

Her dress has become unfastened and has fallen from her shoulders, and the delicate fingers cannot stop their almost mechanical motion to replace it.

The artist has omitted the more repulsive features of extreme poverty, preferring to represent his ideal as a woman, who, though poor, is still refined, and avoids instinctively the conventional accessory of poverty-rags. He has been successful in catching the poet's ideas, aided by his own observation of living instances among our toiling women, the misery of whose lives no poet or artist can exaggerate.-New York Herald, October $16,1875$.

In Constant Mayer's illustration of Hood's "Song of the Shirt," he has succeeded in doing something remarkable-he has poetized a poem.

Mr. Mayer has rarely painted a face containing so much expression, poetry, and sentiment. The large, wistful eyes, heavy with the work of the long and weary night, and yet telling a story of aspirations, of blighted hopes, and a better and happier past, the sad expression of the mouth, the wan look about the cheeks, and the nervous, wearied contraction of the muscles, all tell the story of the idea as it has never before been told upon canvas.

Peculiarly felicitous is the expression of the effect of the cold gray light of early morning, while the drawing of the figure is beyond reproach. It is, indeed, one of the pictures that live and are remembered as the exposition of a poetic temperament and a rarely facile power of execution. $-N e z u$ York Evening Express, October 16, 1875.

398. W. Malecki, Vienna.

Pupil of Kaulbach. Medals at Munich, Vienna, Berlin, and Düsseldorf.

An Algerian Camp, Twilight.

$$
\text { A. D. Vorce, Hartford, Conn. }
$$

399. Louis Toussaint, Düsseldorf. A Critical Moment.

N. A. Frankel, Louisville.

(\$200.)

400. George A. McKinstry, Hudson, N. I. (See No. 278.) Mare and Foal.

A picture painted by the artist in Normandy, with characteristic French landscape. Broad and effective in technique. 
401. C. A. Platt, New York. (See No. 38.) The Grand Pre, Nova Scotia.

(\$200.)

A landscape of exquisite sentiment, admirably expressing atmosphere and distance. Quiet and unostentatious, but full of merit.

402. William Morgan, A. N. A., New York. (See No. IO3.) *The Knitting Lesson. (Illustration, page xxxvii.)

One of Mr. Morgan's charming pictures of child-life. This represents two peasant children-of Brittany, maybe-one of whom is initiating her younger sister into the mysteries of the stitch. The little one looks on with deeply interested expression. There is a very pleasing harmony in the coloring of the picture and it is effective in its technique.

403. M. J. Heade. (See No. 82.) Sunset, St. John's River, Florida. James S. EARle \& Sons, Philadelphia.

404. Edward Moran, A. N. A., New York. (See No. I 72.) New York Bay from the East River Channel.

GEORge H. MOORE, Louisville.

We look down the river from a point a short distance below where the Brooklyn bridge crosses it. At the left, the gray circular structure is Fort Castle William on Governor's Island, and further to the left the military barracks may be seen. The forest of masts on the extreme right obscures the lower portion of New York City, where are the Battery Park and Castle Garden. There is the effect of a breezy day in the picture, and the boats seem actually to move in the turbulent water. There is also a good portrayal of action in the figures in the boats.

405. Carl C. Brenner, Louisville. (See No. 7I.) * Early Autumn.

406. J. M. Tracy, Greenwich, Conn. (See No. I48.) * Summer Woodcock-Shooting.

A portrait of the pointer "Banjo," which took the first prize at Pittsburgh in $188 \mathrm{r}$; - the only descendant of the English dog "Drake" that has ever been brought to this country.-Artist's Note.

407. Bruce Crane, New York.

B. New York, I857. Pupil of A. H. Wyant, N. A. First exhibited in the National Academy, I878. Studied abroad in 1878 and I882. Member of the Society of American Artists and the American Art Union.

* At Set of Sun.

A sunset after a rainy afternoon. 
408. Prof. G. Castagnole, Florence.

Filippo Lippi and Lucretia. Mrs. J. M. ReEd, Louisville.

Lippi was an artist, engaged to Lucretia, a noble lady, whose father forced her into a convent to prevent the marriage. Lippi, ignorant of her retreat, was engaged by the convent authorities to paint an altar-piece representing the Holy Trinity. Lucretia was selected by the sisters as the model for the Virgin in the picture. The painter and model recognized each other during the painting, and, escaping from the convent, were married. Both were excommunicated. Lucretia died soon afterward, and Lippi became a monk, known as Fra Filippo Lippi. He continued to paint, however, as long as he lived. There is another version of this story, which, if true, is not creditable to Lippi. It will be found in the work of VASARI. (Lives of Painters, Sculp. tors, Architects, etc.)

409. J. Ogden Wood, Paris.

B. United States. Has studied in America and abroad. Pupil of Van Marcke, Paris.

Landscape and Cattle.

Thomas A. Wilmurt, New York. (\$I 50.$)$

Excellently drawn cattle, in a pleasing landscape.

410. Edgar M. Ward, N. A., New York. (See No. I47.) The Collar Shop.

$(\$ 300$.

A carefully painted, realistic picture.

4II. William Gedney Bunce, New York.

B. Hartford, Conn., I842. Pupil of William Hart, N. A., New York; Andreas Achenbach, Dusseldorf, and Clays, of Brussels. Spent twelve years in study in Europe. First exhibited, in the Salon, Paris, I875.

An Old Windmill.

A quiet, lazy afternoon-not a breath of air stirring, characteristically Hollandish in sentiment, and one of Mr. Bunce's best pictures.

4I2. Joseph R. Woodwell, Pittsburgh. (See No. 27.)

Woods by the Sea. J. J. Gillespie \& Co., Pittsburgh. (\$200.)

4I3. Contenieux.

(A Belgian artist.-No definite information at hand concerning him.)

The Butler.

Dr. J. R. Leaming, New York.

4I 4. Aguilar.

(A Spanish artist. - No definite information concerning him at hand.)

The Bull-Fighter's Wife,

Dr. J. R. Leaming, New York. 
4I 5. General S. W. Price, Nicholasville, Ky.

B. Kentucky. Painted in Lexington and Louisville portraits of many prominent men, and a number of genre pictures. Is still living, but is now blind from a wound received in battle in the late rebellion.

$\left.\begin{array}{l}\text { 4I5. Caught Napping. } \\ \text { 4I8. "Gone Up." }\end{array}\right\}$ Companion Pictures.

(\$300 each.)

These two pictures tell their story completely enough. The negro, who probably has been left on guard, has fallen asleep and is captured. The expression of his face is very characteristic.

416. Percy Moran, New York. (See No. 23.) Young Fishermen.

A study of several children fishing from a boat, in a quiet stream shaded by tall trees along its banks. The boat is near the shore-bordered by reeds and tall grasses, and these form an effective background for the figures. There is a pretty sentiment in the picture, which is not "finished," at the expense of any strength or truthfulness to Nature.

417. T. L. Smith, A. N. A., New York. (See No. 55.) An Autumn Day.

Mr. Smith devotes himself especially to the painting of winter scenes, but this picture shows that he can appreciate the beauty and sentiment of a milder season. The bright, luminous sky and carefully painted foliage form an exquisite color combination, and the picture does credit to Mr. Smith's reputation. It considerably suggests the early manner of Rousseau.

\section{I8. General S. W. Price. (See No. 4I 5.)}

4Ig. Carl C. Brenner, Louisville. (See No. 7I.) *Autumn Leaves.

Another view of Beech woods by Mr. Brenner. This time he shows us the autumnal aspect of one of his favorite haunts.

420. Frederick P. Vinton, Boston.

B. Bangor, Maine, I846. At seventeen years of age studied under W. M. Hunt in Boston. In 1875 went to Paris and became a pupil of Bonnat. Afterward studied under Dietz and Duveneck, in Munich. Returned to America, 1878.

Mother and Child.

42I. Daniel Huntington, P. N. A., New York.

B. New York City, I816. Pupil of S. F. B. Morse, N. A., I 835-36. Afterward studied anatomy and drawing in Rome, with Ferrero, and drew at the French Academy (the old Villa Medici) in the 
same city. He studied one year in Paris, and a year in London ; pupil of the Royal Academy and member of the Kensington Life Academy. First exhibited in the National Academy, I 837 . Elected member of the National Academy, 1840. President of the Academy, I862-69, and again elected in 1877 , remaining in office to the present time. Also President of the American Art Union.

Few of our painters have exhibited greater versatility of talent, or more broad and pure artistic sympathies.-Tuckerman, Boole of the Artists.

* Lying in Wait.

$(\$ \mathrm{I}, \mathrm{OOO}$.

422. Miss Jennie Logan, Shelbyville, Ky.

Royal Dessert of Kentucky.

423. John Mulvany. (See No. I 2.)

Back to the Wigreram. Major W. H. Thomas, Louisville.

The return of an Indian maiden who has been at school among the whites.

424. J. B. Botto, Louisville, Ky.

B. Louisville, Ky. Pupil of Alexander Defaux, Paris.

Early Spring on Fern Creek.

A careful, characteristic study.

425. J. G. Brown, N. A., New York. (See No. I 57.)

"May I Come In?"

James S. EArle \& Sons, Philadelphia.

(\$600.)

A pretty, but rather bashful little girl standing in a doorway. Background of bright landscape. Figure in shadow.

426. Vergilio Tojetti, New York. (See No. I Io.) Uncle Tom and Little Eva.

(\$350.)

From "Uncle Tom's Cabin." Uncle Tom, holding the child on his knee, is reading to her.

427. Gilbert Gaul, N. A., Spencer, Van Buren County, Tenn.

B. Jersey City, N. J., I855. Studied in the National Academy of Design and with J. G. Brown, New York. First exhibited in the National Academy, I872. Elected Academician, ISS2. Nember of the American Art Union.

* Silenced.

(\$ I , OOO.)

(Illustration, page vii.)

"Silenced," by Gilbert Gaul, N.A., in many respects is one of the most powerful pictures that has been painted in this country. It represents a recently deserted battle-field on a moonlit night in winter. Dead bodies 
are strewn over the ground, and a dismembered cannon, silenced, stands in the middle-distance, suggestively pointing toward the hazy distance. The moon is not visible in the picture, but the moonlight falls upon the snow, and here and there it glistens, reflected from parts of the cannon or an occasional button or weapon. A soldier, wounded and left for dead, has regained consciousness and has partly raised himself on his left arm. There is no one near to.help him, and his head sinks upon his breast as he sees his late comrades lying dead around him. The dead soldier in the foreground lies as rigid as only a dead body can. In this figure Mr. Gaul has succeeded in painting the effect of violent death with startling and horrible realism, yet his picture has a fascination that attracts one again and again. A wierdness and mystery pervade the subject, out of which the imagination may draw much food for thought.-The Art Union, May, 1884.

428. James Crawford Thom, New York.

B. United States. Pupil of Edouard Frere, Paris. First exhibited, Royal Academy, London, I864.

In the Wood. Grady \& McKenver, New York.

429. Edward Gay, A. N. A., New York. (See No. 233.)

*Dordrecht, Evening.

430. Miss A. Klumpke, Paris.

(No definite information at hand regarding this artist.)

In the Sixteenth Century.

William Wiswell, JR., Cincinnati, O. (\$400.)

An extremely strong, effective picture of a young woman in sixteenth century costume.

431. Hamilton Hamilton, New York. (See No. 300.)

* The Listener.

432. Charles Brenner, Louisville.

The Old Clay Pipe.

A very realistic study.

433. Walter Blackman, Paris. (See No. IO4.)

Night. American Art Association, New York. (\$I75.)

An exquisitely beautiful ideal.

434. W. S. Macy, New York. (See No. 240.)

Winter.

N. Sarony, New York. (\$400.)

435 T. S. Barber.

Landscape.

Hegan Brothfrs, Louisville. (\$IOO.)

436. Carl Weber, Philadelphia.

Scene in $W^{\top}$ estphalia. HARRIson EARL, I'hiladelphia. 
437. T. L. Smith, A. N. A., New York. (See No. 55.)

*An Old Mill by Moonlight.

One of the best of Mr. Smith's winter studies.

438. Robert Burns Wilson, Frankfort, Ky.

Portrait of Mayor E. H. Taylor, of Frankfort, Ky.

439. Carl Herpfer, Munich.

$A$ Christening Party in the Time of Louis XVI.

$(\$ 5,000$.

R. F. Field \& Co., New York.

The interior of a handsome French salon-suggestive of Versailles and Fontainebleau-and sixteen figures, attired in the gorgeous costumes of the period.

440. Arthur Quartley, A. N. A., New York. (See No. II3.) On the Zuyder Zee.

Very suggestive of the manner of Clays. A thoroughly truthful study of the characteristic water and boats off the Amsterdam coast.

Morston Ream, New York.

44I. T. S. Barber.

Landscape.

Hegan Brothers, Louisville.

$(\$ 100$.

442. Percy Moran, New York. (See No. 23.)

$A$ Cabbage Patch.

443. Paul Marny, Paris.

A View in Rouen. (Black and White.)

N. Sarony, New York. (\$30o.)

444. John R. Stites, New York.

B. Buffalo, New York, I836. Self-taught. Practiced his profession ten years in Chicago, five years in New Orleans, and is now a resident of New York City. Elected a member of the Chicago Academy of Design, 1876.

An Autumn Study.

$(\$ 100$.

445. Miss A. Klumpke, Paris.

A Study Head.

William Wiswell, JR., Cincinnati, O. (\$150.)

446. Albert Bierstadt, N. A., New York. (See No. 30.)

Landscape in the Yosemite.

George M. Pullmax, Chicago, Ill. 
447. J. H. Dolph, A. N. A., New York. (See No. 210.) * The Page.

Carefully painted, fresh and bright in color and excellent in qualities.

448. Peter Moran, Philadelphia, Pa. (See No. 99.) *By the Sea.

449. Thomas W. Wood, N. A., New York.

B. Montpelier, Vermont, I823. Painted portraits there until 1857, when he entered the studio of Chester Harding, Boston, soon afterward going to Paris (where he opened a studio), and visiting Switzerland and Italy. Studied for a time in Florence and Rome, and afterward in London. Returned to America, 1860. Painted portraits in Louisville, Ky., and Nashville, Tenn., until I867, when he settled in New York. First exhibited, National Academy, New York, 1858. Elected Member of the National Academy, I87I. President of the American Water-Color Society from 1878 to the present time. Vice-President of the National Academy since 1879. Member of the American Water-Color Society, New York Etching Club, and American Art Union. Honorary Member of the British Society of Painter-Etchers.

As a colorist, Wood is forcible, and as a delineator of character he never accepts the ideal, but goes direct to Nature for his models. In the composition of his pictures every thing is clearly drawn, and he secures attention by the directness of his story.-Art Journal.

* A Daughter of Eve.

(\$800.)

A picture by T. W. Wood, "A daughter of Eve," is probably the best work ever painted by this artist. It is one of the genve creations for which Mr. Wood is so famous. A ragged little girl with a bundle of newspapers under her arm holds up an apple for her boot-black companion to bite. The picture is eminently characteristic of New York, is bright, full of animation, is well drawn and charmingly painted.-Louisville Courier-Journal.

\section{Charles Francois Daubigny.}

B. Paris, I8I7. Pupil of his father and of Paul Delaroche, and for three years a student in Italy. Was awarded medals, I848, I853, I855, I857, I859, and I867. Was made a member of the Legion of Honor in 1859 , and an officer thereof in 1874 . D. 1878 , and the same year the Exposition Universelle accorded the "Diploma to the Memory of Deceased Artists" to his memory.

The art of this illustrious master consists in choosing well a bit of country, and painting it as it is, inclosing in its frame all the simple and naive poetry which it contains. No effects of studied light, no artificial and complicated 
composition, nothing whatever which allures the eye, surprises the mind, and crushes the littleness of man.-Edmond ABout.
Landscape.
Morston Ream, New York.
$(\$ 600$.

45 I. J. Windmere.

Near Baden.

Mrs. P. WOOLDRIDGe, Louisville.

A small picture of decided merit, though no particulars of the artist are at hand. The sunset sky is particularly bright and luminous.

\section{Sir Anthony Van Dyck.}

B. Antwerp, 1599. After studying under Henry Van Balen, he entered the school of Rubens in 16I5, and soon became the favorite pupil of his master. Later, Van Dyck visited Italy to study the works of Titian and Giorgone, and there, by his elegance and refinement of manner, made many friends. He lived successively in Venice, Genoa, and Rome, and painted many portraits and religious works. In 1632 he went to England, where he was well received by the King, and was appointed principal painter in ordinary to the King and Queen, who frequently visited his studio and passed hours in familiar conversation with him. Three months after his arrival in England, the King conferred upon him the honor of Knighthood and settled upon him a pension of $£ 200$ yearly. While in London, Van Dyck earned large sums of money, lived in a style of lavish magnificence, and entertained his friends right royally. He died in $164 \mathrm{I}$ at his home in Blackfriars, and was buried in St. Paul's Cathedral. As a portrait painter, Van Dyck occupied the first place, with Titian. The works of Van Dyck are numerous and are found in all large and good collections.

Portrait of Rubens. Col. John Farrell, New York. $(\$ 5,000$.)

This picture was painted about $16_{3} 6$, for an ancient Royalist ,family in Gloucester, England, and is doubtless a duplicate of the portrait Van Dyck painted for King Charles I.

The following is from the New York Tribune, of November 19, 1882: ... Colonel Farrell purchased this painting at the sale of an old family mansion in England, some years ago, and experts to whom he has submitted it have pronounced it a Van Dyck. It certainly possesses many of the characteristics of Van Dyck's second or English manner-in which his works are distinguished for their silvery tones and for the delicacy, brilliancy, and at the same time solidity and firmness of their painting. As a portrait of Rubens, this work is an almost exact duplicate of the picture by Van Dyck in Windsor Castle. The handsome face of the artist is surmounted by a broad-brimmed cavalier hat with a gold cord and tassel. He wears a dark cloak or mantle thrown over his shoulders and a pointed lace collar. The face is exquisitely painted, strong in the lights and tender in the shadows; the delicate pearly grays-the despair of so many artists-are expressed, apparently, with ease. 


\section{Hans Frederic Gude.}

B. at Christina. Studied at Dusseldorf. $\mathrm{He}$ is considered the best landscape painter of his country, and has received many high honors from various governments. Is Chevalier of the Orders of St. Olaf of Norway, of the Lion of Zahrengen of Bade, of the Red Eagle of Prussia, of Francis Joseph of Austria, etc., and is a member of the Academies of Stockholm, Copenhagen, Vienna. Berlin, Amsterdam, Rotterdam, etc. Has received many medals in various European countries, and also was given one at Philadelphia, in 1876 .

\section{A Norwegian Landscape.}

William Henry Davis, Cincinnati, O.

People have said that this painter's art is like a growth of Nature, gradual, calm, constant; it certainly has ever been near to Nature when in her ten$\therefore$ derest moods; it infuses beauty into grandeur, and throws gentleness over forms rugged and defiant.-A TKInson.-ArtTour to the Northern Capitals in Europe.

454. Leon Delachaux, Philadelphia. Strawberrying. HARrison EARL, Philadelphia.

(\$200.)

455. William Hahn, New York. (See No. 265.) "My Turn Now."

A picture painted by the artist in San Francisco, representing a number of gamins obtaining a surreptitious view of a circus performance. The picture contains considerable character and tells its story very completely.

456. J. G. Brown, N. A., New York. (See No. 157.)

\section{An Old Shaver.}

$(\$ \mathrm{I}, \mathrm{000})$

This is a fair contrast to the "little shavers" Mr. Brown has painted, and is one of his best pictures. The old man's face is full of character, and his stiff, nervous motions are well suggested. The various objects of still lifethe cup, the open book, and the geranium blooming in its pot on the table, are also painted with a high degree of realism.

\section{J. F. Kensett, N. A.}

B. Cheshire, Conn., 1818. Studied bank-note engraving in his youth and practiced art in his leisure hours. Went to England after a time, and sent a picture to the Royal Academy in 1850 , which was highly praised by the art critics. Remained in Europe seven years, spending two years in Rome and making excursions to Naples, Switzerland, the Rhine, etc. Elected member of the National Academy, 1849. D. I873.

\section{White Mountain Scenery.}


Kensett is the Bryant of our painters; a little sad and monotonous, but sweet, artistic and unaffected.-JARves.-Art Idea.

Kensett's best pictures exhibit a rare purity of feeling, an accuracy and delicacy, and especially a harmonious treatment perfectly adapted to the subject.-Tuckermian's Book of the Artists.

\section{Theodore Rousseau.}

B. Paris, I812. Pupil of Guillon-Lethiere. First exhibited, Salon, 1834. Medals, I834, 1849, and 1855. Legion of Honor, 1852. One of the eight Grand Medals of Honor, Exposition Universelle, Paris, 1867. D. 1867. Diploma to the memory of Deceased Artists, I 868.

\section{Landscape.}

Morston Ream, New York. (\$I,500.)

Theodore Rousseau has been for twenty-five years the first apostle of truth in landscape. He made a breach in the wall of the historic school, which had lost the habit of regarding Nature, and servilely copied the bad copyists of Poussin. He emancipated the landscape painters as Moses formerly liberated the Hebrews. He led them into a land of promise where the trees had leaves, where the rivers were liquid, where the men and animals were not of wood. . . . His incontestible talent was contested by all the world. It is only to-day that his reputation is made.-Edmond ABout.-Our Artists in the Salon (1857).

459. Charles Francois Edouard De Beaumont, Paris.

B. at Lannion (Cote du Nord). Pupil of Boisselier. Medals, i 870 and 1873. Cross of the Legion of Honor, 1877. Hors concours. The Temptation of St. Anthony.

St. Anthony was an Egyptian, born at Alexandria. Early in life he was left an orphan with one sister. He inherited great wealth and high rank. One day, having entered a church, he heard these words, "If thou wilt be perfect, go sell all that thou hast and give to the poor, and thou shalt have treasure in heaven;" and also, "Every one that hath forsaken houses, or brethren, or sisters, or father, or mother, or wife, or children, or lands for my name's sake, shall receive a hundred-fold, and inherit eternal life." Such an impression was made upon him, that Anthony divided his wealth with his sister, gave his own share to the poor, and joined a company of hermits in the desert. His life here was so pure as to arouse the hatred of Satan, who sent demons to tempt and torment him. They whispered to him of all he had left behind, and pictured before his mind the attractions of the world. But he prayed until great drops stood upon his brow, and the demons despaired. They then placed delicious food before him, and, assuming the forms of lovely women, tempted him to sin. Again he resisted all their arts with prayer, but he suffered so much that he determined to go yet further into the desert, and he found a cave where he thought Satan could not discover him. But here demons continued to torture him, and tore him with their claws. Anthony suffered all manner of persecutions from the powers of evil, but remained steadfast to the faith through them all; and when Satan was obliged to acknowledge himself powerless over the good man, Christ 
Himself appeared to Anthony, commending his constancy and promising that his name should become famous throughout the world. Anthony preached for many years, comforted the sick and afflicted, and expelled demons, over whom he had gained great power. St. Anthony, January I7, A.D. 357-Condensed from Clement's Handbook of Jegendary Art.

For wonderful technique and for exquisite grace in lines, De Beaumont has never painted any thing superior to his "Temptation of St. Anthony." And in this picture he shows how much stronger may be the effect of a suggestion of a fact than the full representation of the fact itself. De Beaumont might have attempted to paint for us the old man's face tortured by the expression of his struggle with temptation, but he would most probably have failed in such an undertaking, or at least he would have given us something that might have satisfied us without calling upon our imagination or particularly impressing us. But here, the old man's face hidden in his Bible, and his hands rigidly closed, tell the story of terrible temptation and struggle with exactly the degree of power that is possessed by the imagination of the spectator. There is a wonderful amount of "reserved force" in this picture, and at the same time a completeness in it. Every element has its meaning, and no part of the work is in any way slighted in its expression.-Louisville Courier-Journal.

\section{A. Gittard.}

(No definite information concerning this artist is at hand.)

\section{Treilight.}

William Semple, Louisville.

There is something about this picture that is suggestive of one of Corot's very good pictures-not the ordinary Corot of doubtful authenticity, so common in American collections. The sunset glow in the luminous sky, the broadly-painted landscape, the exquisite effect of distance, and the shining water reflecting the bright sky, contribute to produce one of the most poetic and pleasing of all the landscapes exhibited this year.

46r. C. B. Coman, New York. (See No. 360.) * Windmills in Holland.

A fresh, bright picture, with excellent sky and atmospheric effect; picturesque in subject and true to Nature.

462. Paul Weber, Munich.

B. in Germany, 1823. Studied in Frankfort. In 1848 came to the United States and settled in Philadelphia. Returned to Europe in $\mathbf{1} 858$, and was appointed Court Painter at Darmstadt. Lately he has resided in Munich.

\section{Scene in the Black Forest.}

C. Janentzky, Philadelphia.

(\$800.)

A glowing sunset sky and most picturesque landscape, with stream coming into the foreground. The effect of the sunshine coming toward the spectator through the trees and falling upon the water is peculiarly fine. 
463. Robert Hopkin, Detroit. (See No. 13.)

Coming up the Clyde.

L. A. M'Creary, Detroit.

464. Joseph R. Woodwell, Pittsburgh, Pa. (See No. 27.)

A Trout Stream in Pennsylvania.

J. J. Gillespie \& Co., Pittsburgh. (\$IOO.) 


\section{Section II.}

\section{Scufptures int the Ziotunta.}

\section{Joel T. Hart.}

B. Clark County, Ky., I8Io. After a slight common-school education, was apprenticed to a stone-cutter in Lexington, Ky., where he began to model busts in clay. In I849 he went to Florence, where, for the Ladies' Clay Association, he executed a statue of Henry Clay, which is now in Richmond, Va. Afterward he modeled the colossal bronze statue of Clay now in New Orleans, and also the beautiful marble statue of Clay in the Louisville CourtHouse. He made busts and statues of many other eminent men. Among his ideal works are "Charity," "Woman Triumphant," "Penserosa," etc. Hart had an intensely poetic nature, which showed itself not only in his art works, but sometimes in literary form. Lived in Florence thirty years. D. 18;7.

His ideal productions have been greatly admired, and have placed his name high in the niche of fame. Among these are his "Angelina," "Il Penserosa," and his last and greatest work, known as "Woman Triumphant." Upon this last work he was engaged for over twenty years, and when chided by a friend for not finishing it at once, replied, "The Almighty does not see fit to make a perfect woman in less than eighteen years, and can I hope to make a perfect model in less?". . . . He wrote some exquisitely beautiful poetry, and was a man of rare refinement and culture. . . He died March 2, 1877, at Florence, Italy.-Kentucky Biographical Cyclopedia.

Woman Triumphant. (Sometimes incorrectly referred to as

"The Triumph of Chastity.")

The Hart Memorial Association, Lexington, Ky.

(Purchased, 1884 , by the women of the city of Lexington and county of Fayette, Kentucky, as a memorial of Hart and a testimony of their appreciation of his aim and work.)

The following interesting letter was written at Florence, by Mr. R. J. Menefee, some years ago, when Hart was still living and at work upon his mas- 
terpiece. It was published then in a Louisville paper, and it explains so well the character of Joel Hart and the aim of his work that it is deemed advisable to reprint it here.

"Like many others who have achieved greatness, Mr. Hart has ever been indifferent to the allurements of wealth and pleasure. Living on from year to year studying, writing and toiling with all the enthusiasm of youth, "the sea-mark of his utmost sail" has been a desire to leave one great work to live after him; one work in which all the dreams and hopes of a life should be embodied-around and in which should be thrown that poetic sentiment so rich in his own nature;-one work embracing all the difficulties in his art-a glorious combination of curves and proportions which should for all time delight the lovers of exquisite forms, instruct young ambitions, and write the name of the author in everlasting letters of gold. And he has accomplished it. After nineteen long years of patient labor, he has finished the model, put it in plaster, and it is almost eternal.

There is an interesting fact in connection with the mere material of Hart's model. After Hiram Powers had finished the "Greek Slave," he sold the clay in which she had been modeled to Mr. Hart. This clay had been brought years before from Baltimore, Md., and it is a striking coincidence that from Maryland the clay should have leen dug in which the Cincinnatian, Powers, accomplished the work that made him famous, and in after years that the same earth should, under the superior hand of a Kentuckian, be fashioned into a marvel of beauty so far beyond its first form-the "Greek Slave"-as the latter surpassed all previous efforts of Mr. Powers. "Woman Triumphant" surpasses, in the judgment of various critics, the works of both ancient and modern times.

Many have attempted to describe this wonderful work, and have failed. I, therefore, will not attempt it, as language seems unequal to the task. However, I would say something as to the spirit of the composition. It is a group of two figures only; a perfect woman, possessed of the passions belonging to a superior animal nature;-full, free, symmetrical, faultless-but balanced with a head of rare intellectual form, suggestive of modesty, purity, and nobility of character; a woman capable of the fullest enjoyment, but thoroughly able to resist temptation. Love, in the shape of a bewitching Cupid, has assailed the fair one; has shot arrow after arrow, all of which have fallen at her feet broken. His quiver is exhausted; the last shaft has failed of the mark, and the splendid woman has caught the barbed arrow, and with her left hand has raised it high above her head, out of reach of the villainous little tempter, who struggles hopelessly on tiptoe to regain it. The intensely sweet, indescribable expression on the beautiful face of the woman, the ease and unaffected grace in her attitude, the perfection of her person and the look of eagerness in the countenance of the disappointed Cupid, combine to render this, to me, the most attractive of all sculptures. The composition tells its own story. Virtue is assailed, reason is brought to bear, and all attacks are harmless. It is "Woman's Triumph." To a form most alluring, the artist has given a strong, massive, intellectual, but thor oughly feminine head and face. A perfect equilibrium is at once suggested. Mr. Hart has in one respect followed the antique, but in his general treatment has departed from established academic rules. He has given to his goddess a power of brain proportioned to her attributes, and equal to the proper regulation of a thoroughly perfect animal nature. The head of the 
Venus of the Tribune (the Venus de Medici) is small-too small for beauty according to our standard, but viewed from the mythological Greek standpoint, she is pronounced unequaled. The Greek Venus embodies only those qualities adapted to love and sensual enjoyment; therefore they made her of luxurious person but devoid of brains. Their mythology shows itself in all their Art handed down to us. You find in their Hercules brains enough to indicate a cunning animal, and as he was in the eyes of the ancients the god of physical power, he is a mass of exaggerated muscles. So with the Gladiator of the Louvre. His is a most complete structure for violent athletic contests. In the Apollo of the Vatican (the Apollo Belvidere), is to be found majesty-a superb cranium, and wonderful limbs, appropriate for the god of life, light, intelligence, and speed. The attributes they assigned to Apollo are beautifully expressed in this figure. But Mr. Hart has improved on all these. Appreciating and keenly enjoying all that is beautiful in nature, he has powerfully combined those qualities constituting a superior physical constitution, and has dared to give to woman grace of limbs, perfect proportion, and a healthy cerebral organism. Believing, as he does, that his own countrywomen are unsurpassed for loveliness and power, he has endeavored, and successfully, to produce the highest, purest and most captivating type of the American woman.

With more genius than Canova, he is actually struggling along, while the great Italian had profitable commissions showered upon him. In a pecuniary sense, Canova was fortunately situated by comparison with Mr. Hart, but it is not difficult to discover that in doing too much, he did nothing equal to the power within him, and to-day the rarest of his many works fails to rank with the antiques of the better order. Mr. Hart has been too much of a poetartist to delve for money. Perfection and fame are the lights before his eyes, and although by comparison with other artists of merit he has apparently accomplished little, yet in this last work alone he has wrought a poem that will live like the Iliad."

\section{Joel T. Hart. (See I.) The Morning Glory.}

The Art Gallery of The Polytechnic Society of KenTUCKY, Louisville.

Concerning this exquisite small statue, Dr. E. A. Grant writes:

The rare beauty and premature cievelopment of Italian girls, and the rapid decay and early loss of their charms is proverbial. Mr. Hart had made this peculiarity the subject of much reflection and frequent conversation.

One morning, in going to his studio, his attention was attracted by the marvelous beauty, statuesque pose and early maturity of a little girl-a mere child. In one hand she held a morning glory into which she was thoughtfully gazing, as if reading her destiny in the depth of its delicate petals. The other hand gracefully held a fold of her tunic containing numbers of these quickly perishing flowers. The very ideal of Italian womanhood seemed to stand before the poet-artist;-childhood-morning, its glory. He instantly determined to embody the idea in marble. He secured the child for his model, and her face, form, and expression, as he first saw her in the streets of Florence, became his beautiful ideal "Morning Glory." 
III. G. H. Saul, Florence.

Pupil of Joel T. Hart.

Bust of Joel T. Hart.

The Art Gallery of The Polytechnic Society of KenTUCKy, Louisville.

IV. E. R. Thaxter.

Reproof.

A charming figure of a child slapping the face of a kitten which has killed her pet bird lying at her feet.

V. Joel T. Hart. (See I.)

Bust of Andrew Jackson. (President of the United States.) The State of Kentucky. (From the Capitol at Frankfort, Ky.)

Modeled from life, at the Hermitage, in December, 1838 .

Andrew Jackson was born in South Carolina in ${ }^{1767}$. His father was an Irish emigrant. At the age of sixteen he took part in the war of Independence, at the close of which he studied law and was subsequently able to discharge efficiently some legal duties in Tennessee, for which he was appointed by the Government. Took an active part in the war of 1812 , and in $18 \mathrm{r}_{4}$ was appointed Major-General. Gained the decisive victory in this war, January 8, I8I5, at New Orleans. He was subsequently successful against the Creek tribes, which he subdued. In 182 I was appointed Governor of Florida, and afterward, being brought forward as the Democratic candidate for the Presidency, was electec, I829, and re-elected in 1833 . During his administration he obtained from France 25,000,000 francs for injuries done to the commerce of the United Seates during the Empire. His refusal to renew the Bank Charter in 1833 led to one of the most violent financial struggles on record. He was endowed with inflexible will, ardent patriotism, and was the idol of the people. Died, 1845 .

VI. Joel T. Hart. (See I.) Bust of Henry Clay.

The State of Kentucky. (From the Capitol at Frankfort, Ky.)

To a Kentuckian any biographical data of Henry Clay would be superfluous, and while it should scarcely be necessary even to the visitor to Kentucky, some brief facts regarding the distinguished statesman may not prove uninteresting in this connection, and may recall definitely what may not be well remembered.

Henry Clay was born in 1777 in Hanover County, Virginia. Began the practice of law at Lexington, Ky., in 1797 . Was elected to the legislature in 1803 , and in 1806 was appointed to fill an unexpired term in the United States Senate. Was again elected to the legislature in 1807 and was chosen Speaker. Mr. Clay was next elected to fill another unexpired term in the United States Senate, covering 1809 and 1810 . In $18 \mathrm{II}$ he was sent to the House of Representatives, and was immediately chosen Speaker of the House. He strongly advocated the war with Great Britain, and zealously sustained Mr. Madison's 
war measures. In $18 \mathrm{I}_{4}$ he was appointed one of the commissioners to negotiate the Treaty of Peace of Ghent. In I8I5.was again sent to Congress and again elected Speaker, and retained this position by re-election until r82r. In I8x9-20 he exerted himself for the protection of American industry and rendered great service in the adjustment of the Missouri compromise. In 1823 returned to Congress and was elected Speaker by a large majority. In I824 was a candidate for the Presidency of the United States, but was defeated. The choice for President devolving upon the House of Representatives, $\mathrm{Mr}$. Clay, as Speaker, gave the casting vote in favor of Mr. Adams, whose Secretary of State he became. In I83r, Mr. Clay was again sent to the Senate, and in 1832 was a candidate for the Presidency, but was defeated by General Jackson. In 1833 , when the tariff question was agitating the whole nation to an alarming extent, Mr. Clay prepared his famous "Compromise Bill," which was passed after a hard struggle. In 1839 his name was prominent among the Whig candidates for the Presidency, but General Harrison received the nomination. In 1844 he was the Whig nominee for the Presidency, but was defeated by Mr. Polk. In 1849, again was elected to the Senate, and in the famous ses. sion of 1849-50 devoted his energies to securing the passage of a series of measures known as "the Compromise Acts." His efforts during this session weakened his strength and hastened his death. At the beginning of the session of $185 \mathrm{I}-2$ he was unable to participate in the active duties of his position on account of ill health. He sent in his resignation, therefore, to take effect September 6,1852 , but died on the $29^{\text {th }}$ day of the June preceding. Mr. Clay was one of the greatest orators of his time, and his speeches form some of the most stirring passages in the political history of this country.

\section{Antonio Canova.}

B. Possagno, Venice, I757; D. Rome, I822. Canova's father and grandfather were both sculptors of repute. By the death of his father, Antonio Canova, at the age of three years, came under the care of his grandfather, whose pupil he became. Afterward he studied under Giuseppe Bernardo, called Toretti (the elder), a Venetian sculptor who had settled at Pagnano. At the age of thirteen, Canova was pensioned by the Venetian Government that he might go to Rome to pursue his studies. There, by his industry not less than his genius, he attracted marked attention. At the age of sixteen, disgusted with the conventionalisms of his masters, he began a systematic and laborious study of the ancient masters and of Nature as seen in living models. His knowledge of human anatomy was unsurpassed, and in moulding its forms, and through these forms expressing the most delicate and subtile emotions of the human mind, he was without a rival. His industry, benevolence, and simplicity of character were on an equality with his genius. Of him it was said that, "Decorated with equestrian orders of many sovereigns, decreed noble by many States, dignified by titles, enriched by pensions, received with distinction at all courts, 
desired by all societies, and associated with all the principal academies of Europe, he still preserved the original simplicity and modesty of his character."

Hebe.

The Art Gallery of the Kentucky Polytechnic Society, Louisville.

The freshness of Nature that seems to have inexhaustible sources, suggested the exquisite myth of Hebe, as one who had access to the secret springs of immortal life, and who drew therefrom life-giving nectar for lifegiving deities. Hebe's offices were to preserve youth and freshness, to offer nectar at the Olympian banquets, and to minister to Hera when entering or leaving her chariot. So closely identified with youth were beauty and gracefulness, that it was said that by an unfortunate fate, while passing nectar to the gods, Hebe lost her position and was superseded by Ganymede. Another legend states, however, that she resigned her office on the occasion of her marriage to Heracles.

Canova's statue of Hebe was repeated several times with slight changes in detail. The one on exhibition is, perhaps, one of the most satisfactory. It was produced on the order of a Spanish nobleman, and after his death was purchased for exhibition in America It was obtained from the importer by the late Robert J. Ward.

The cup-bearer of Jove-the goddess of eternal youth-is represented as just descending from the skies. The soft drapery is pressed by the buoyant wind against her person, and partly reveals the beauties of her perfect form. Never has marble more felicitously expressed the soft, warm, living lines of beauty, or embodied more of grace and motion.

VIII. Joel T. Hart, after the antique of Kleomenes of Athens. Joel T. Hart. (See I.)

Kleomenes was the son of Apollodorus, of Athens. Pliny alone mentions this sculptor, who does not appear to have been particularly celebrated among the ancients. From various known facts, it is decided that he lived between 363 and $146 \mathrm{~B}$. C.

\section{The Venus de Medici.}

The Art Gallery of the Kentucky Polytechnic Society, Louisville.

The original of this statue, of which this is probably the finest copy extant, stands in the Tribune of the Uffizi, Florence. It was found in the sixteenth century, in the villa of Hadrian, near Tivoli, and was taken to Florence in 1680 , under Cosimo III Di Medici-whence its title. When found it was in thirteen pieces, and without arms. These were supplied, but it is supposed by many that the position of the original arms is not given in the substitutes. It was executed at a period when Greek art was rapidly declining. Though it has been characterized as a "statue that enchants the world," there is no famous work of sculpture that has been more the subject of diverse criticism. 



\title{
ILLUSTRATIONS
}

\author{
OF \\ SOME OF THE PICTURES
}

IN

\section{¿be QXert Ballery}

OF THE

\section{SOUTHERN EXPOSITION}

LOUISVILLE, KY.

I 884 
The illustrations herewith presented are especially interesting in being, for the most part, fac-simile reproductions of drawings made by the artists themselves. They are not to be considered as "works of art," but as memoranda merely, to convey an idea of the pictures to those who can not visit the exhibition, and to help those who do visit the gallery to recall them afterwards. 


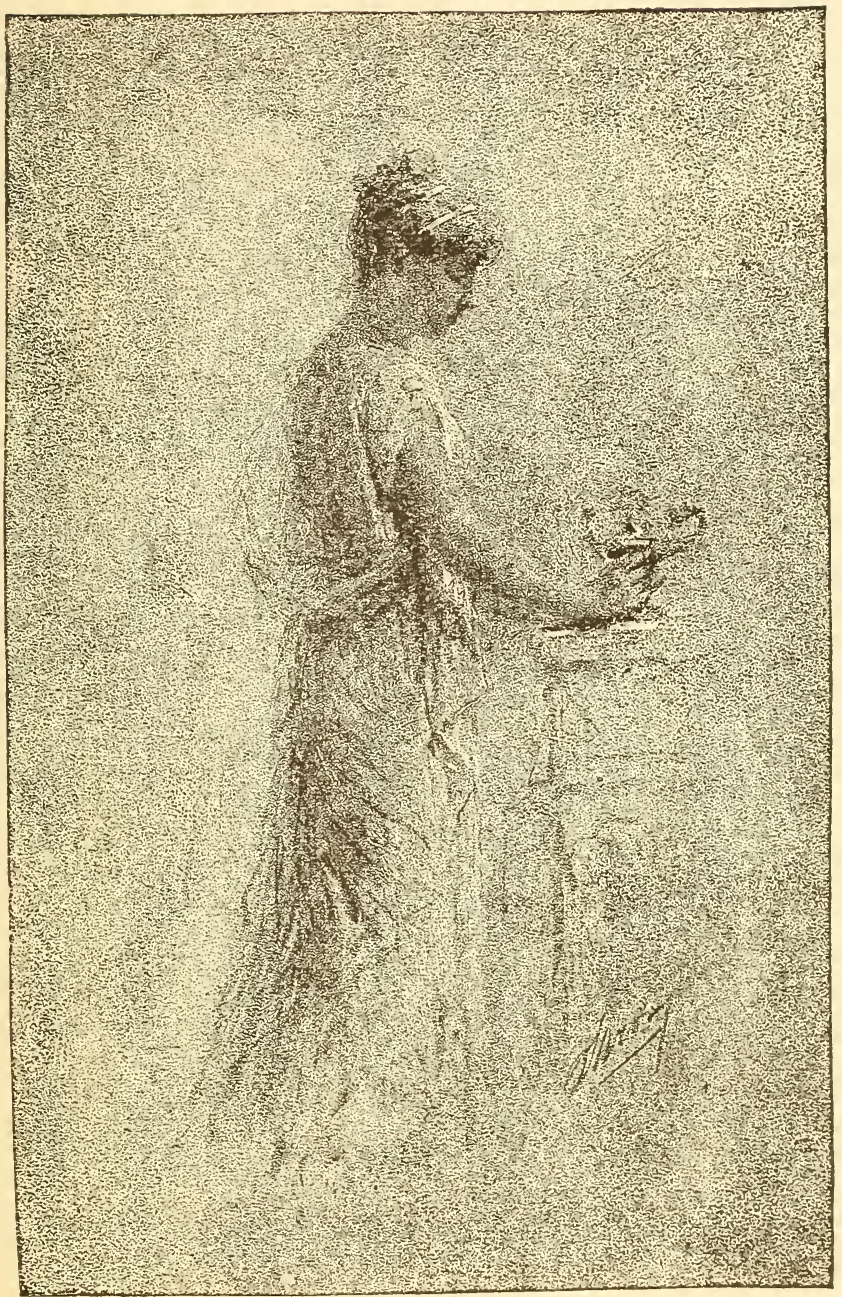

3.-A VESTAL VIRGIN.

N. SARONY. 


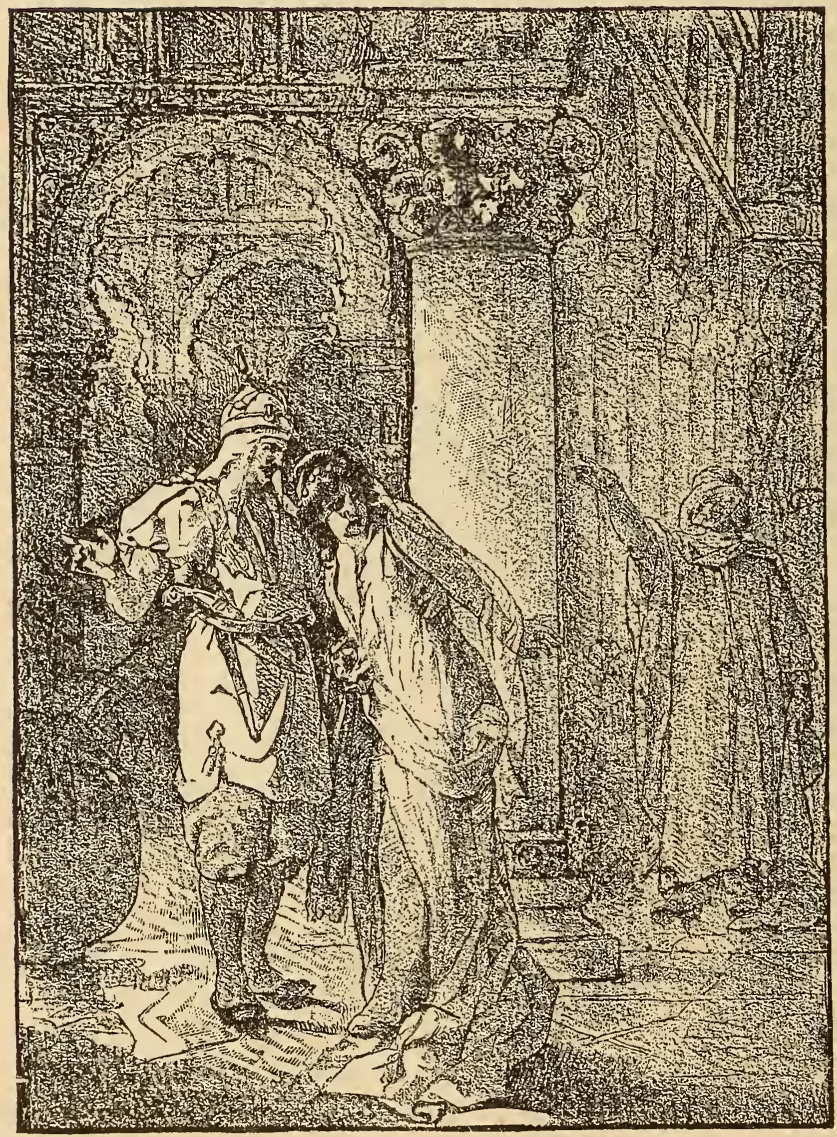

110. -THE VEILED PROPHET.

LALLA ROOKH.

VERGILIO TOJETTI.

(From National Academy Notes, 1883.) 
Louisville, Kentucky, 1884.

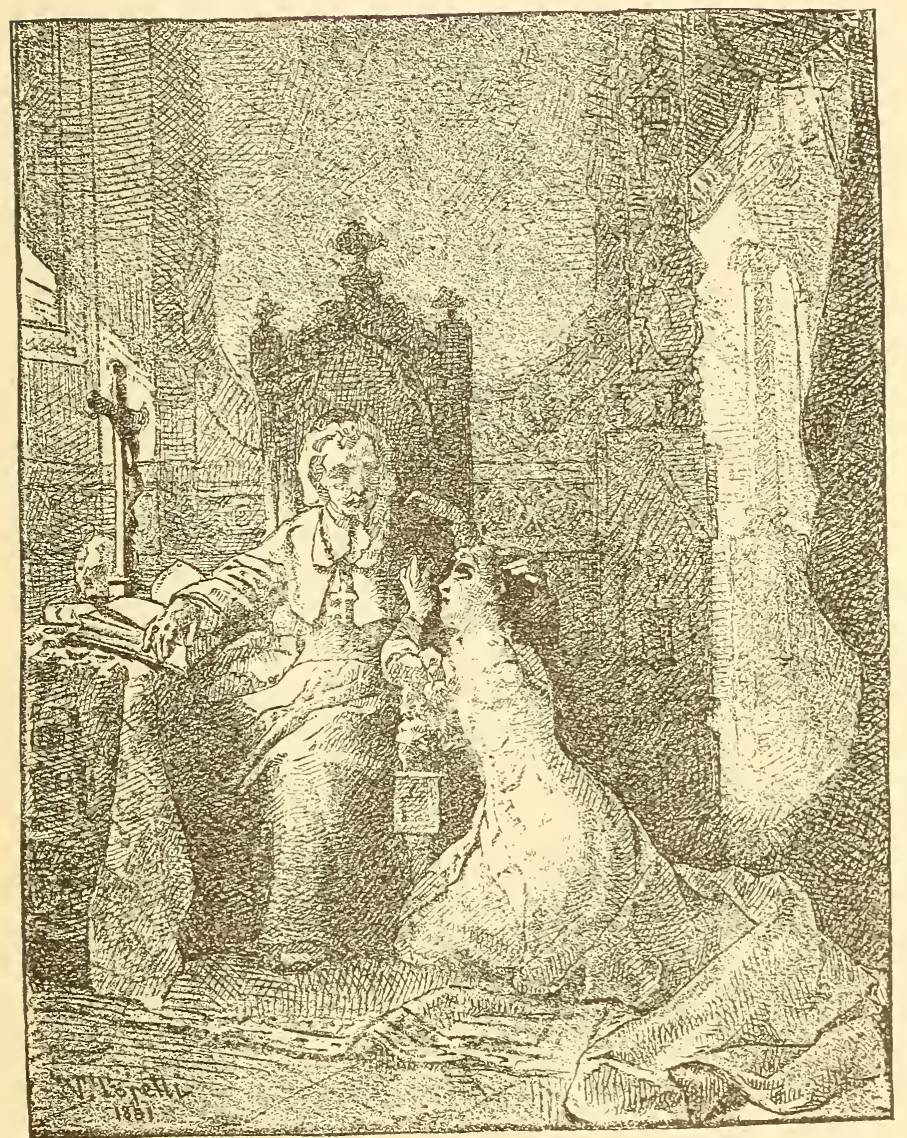

270.-RICHELIEU AND JUL!E.

BULWER'S DRAMA.

VERGILIO TOJETTI.

(From National Academy' Notes, I88r.) 


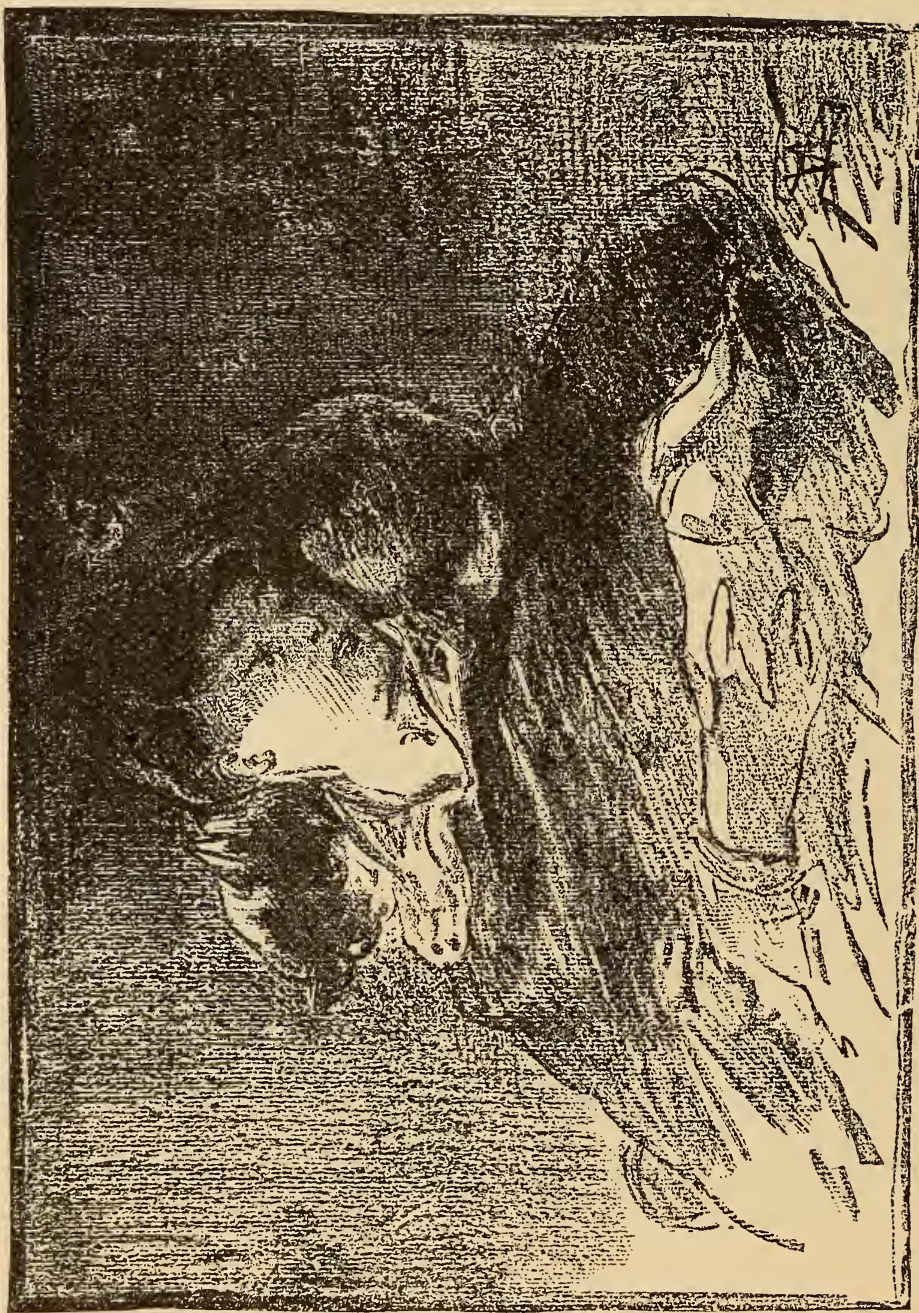




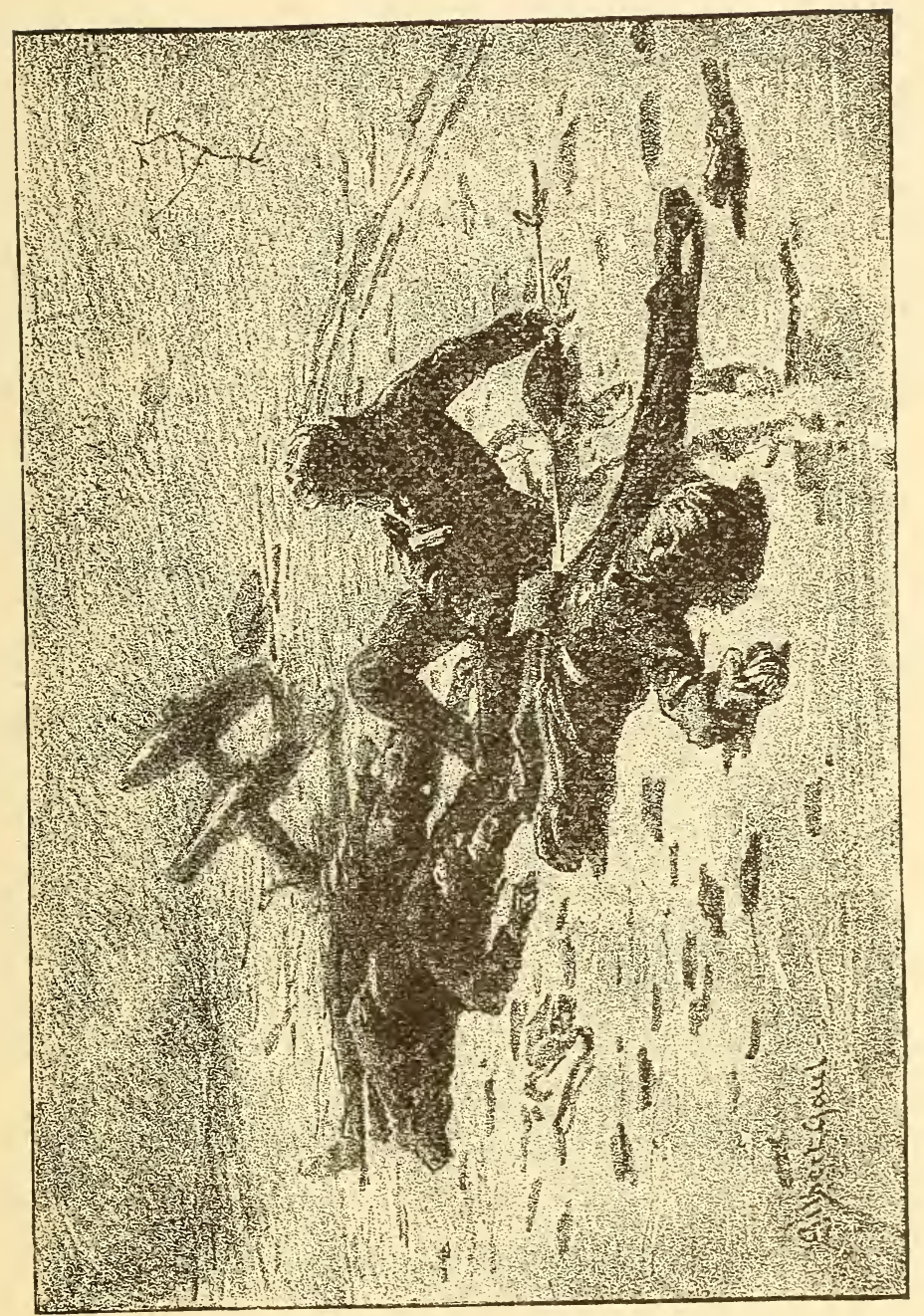

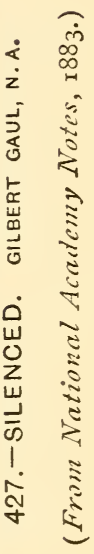




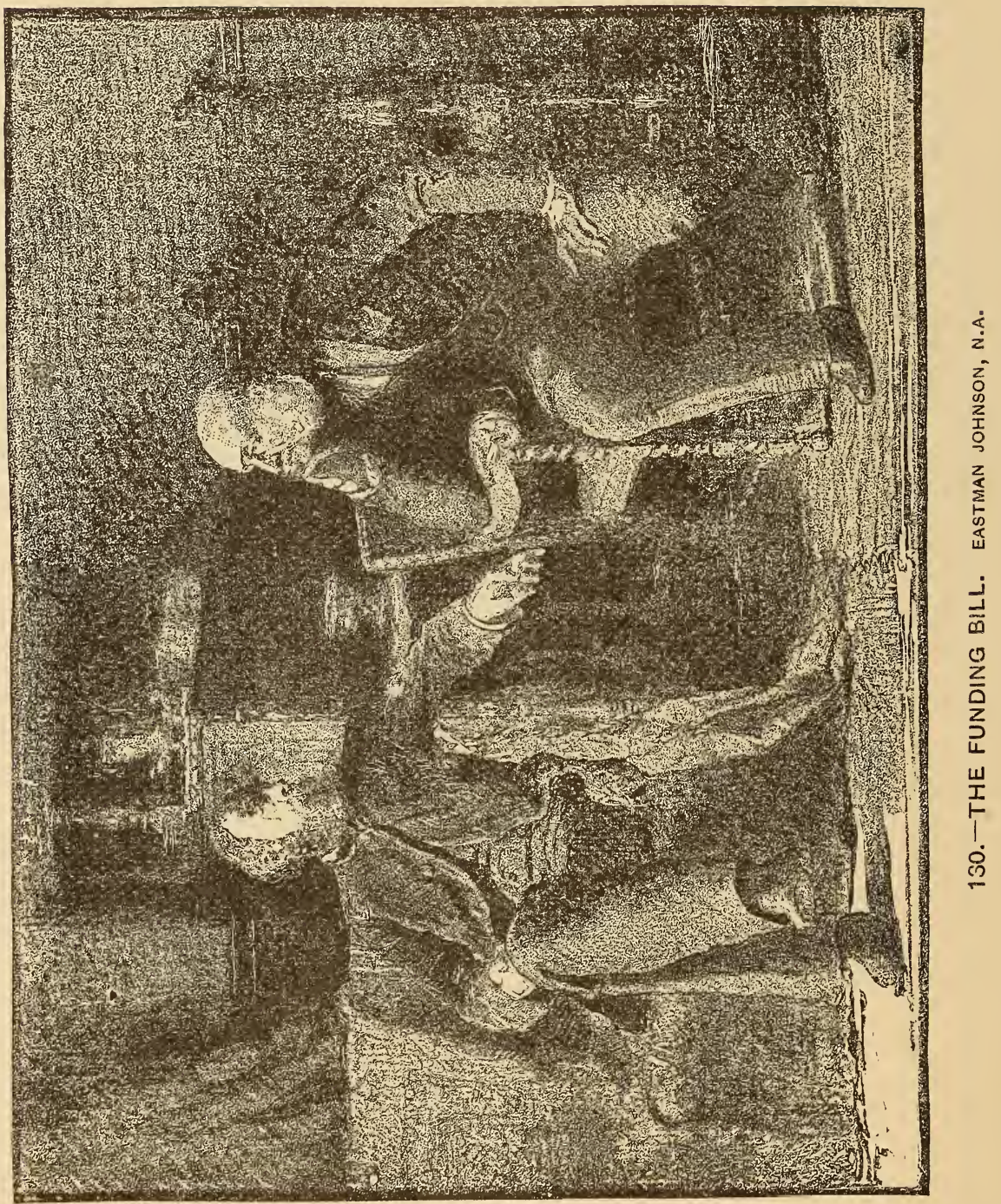

(From National Academy Notes, r88I.) 


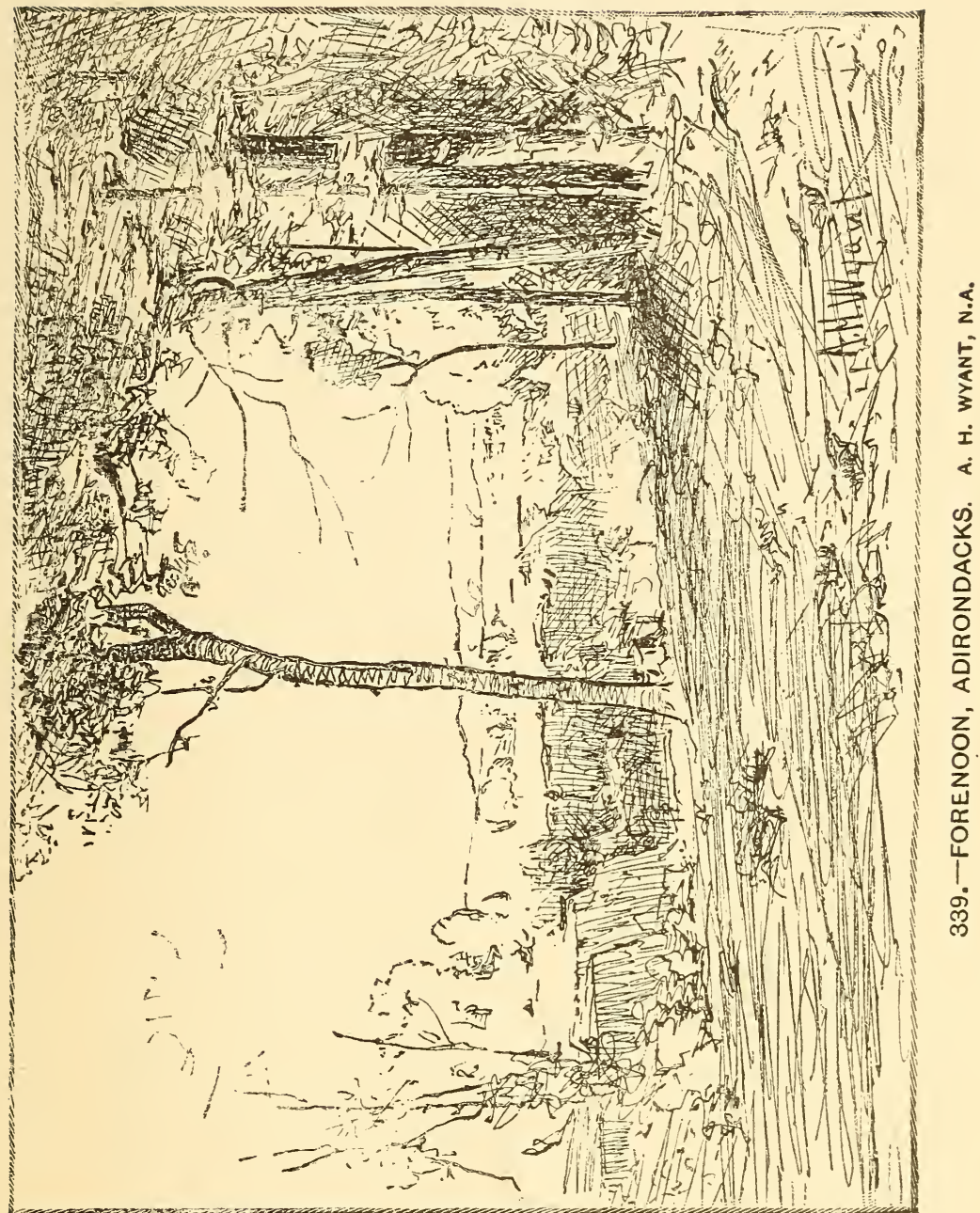

(From National Academy Notes, I884.) 


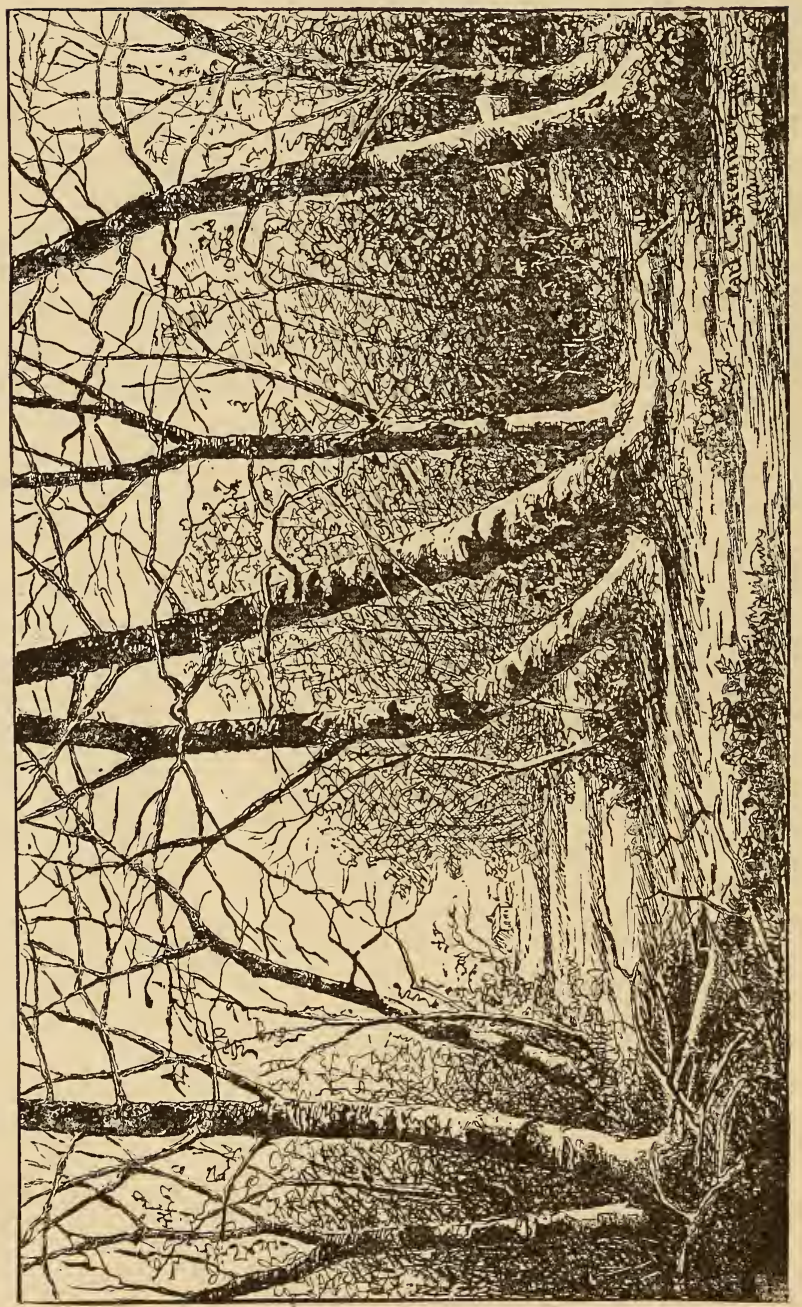

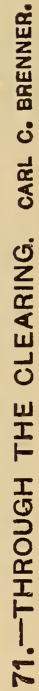




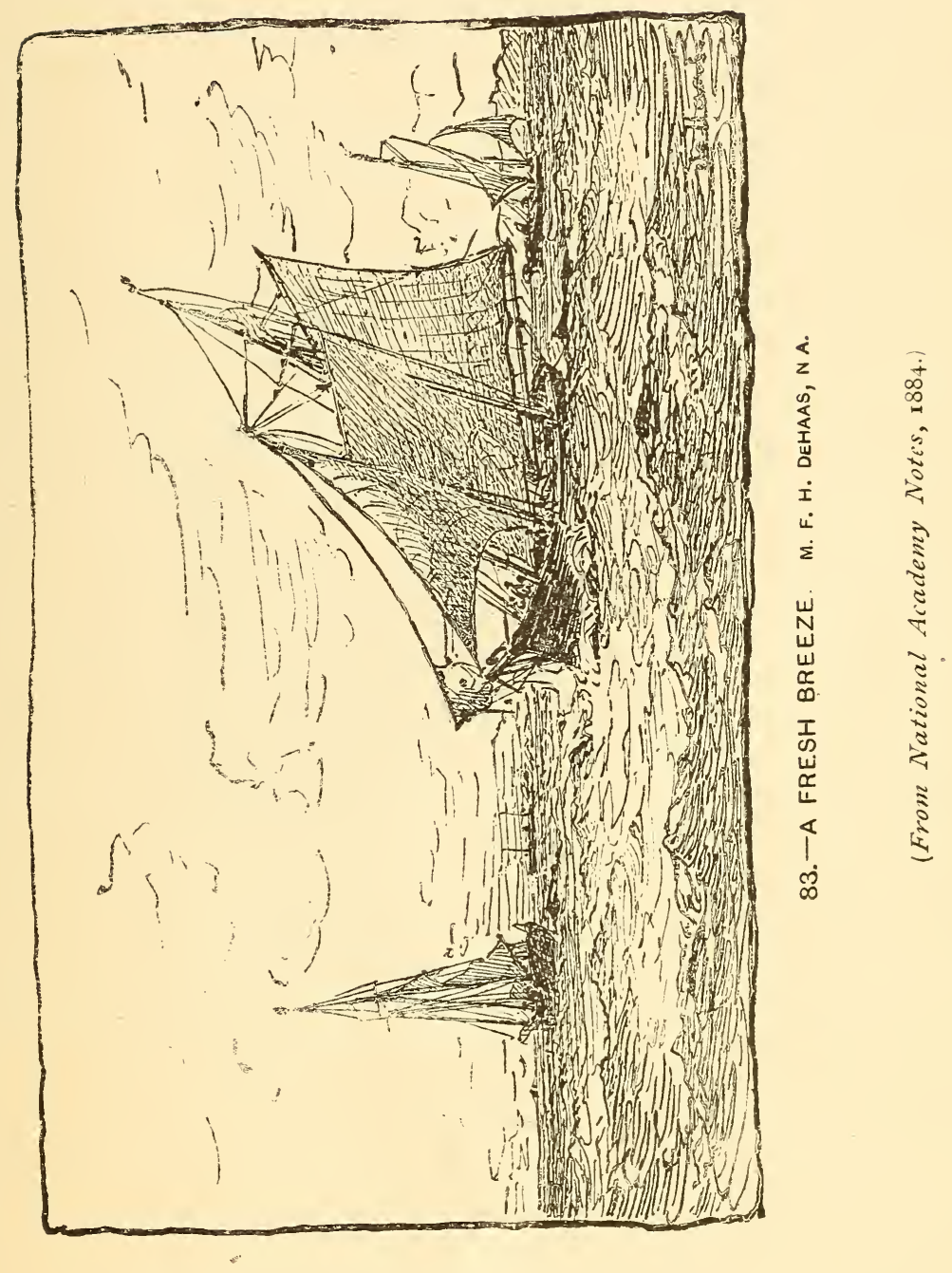



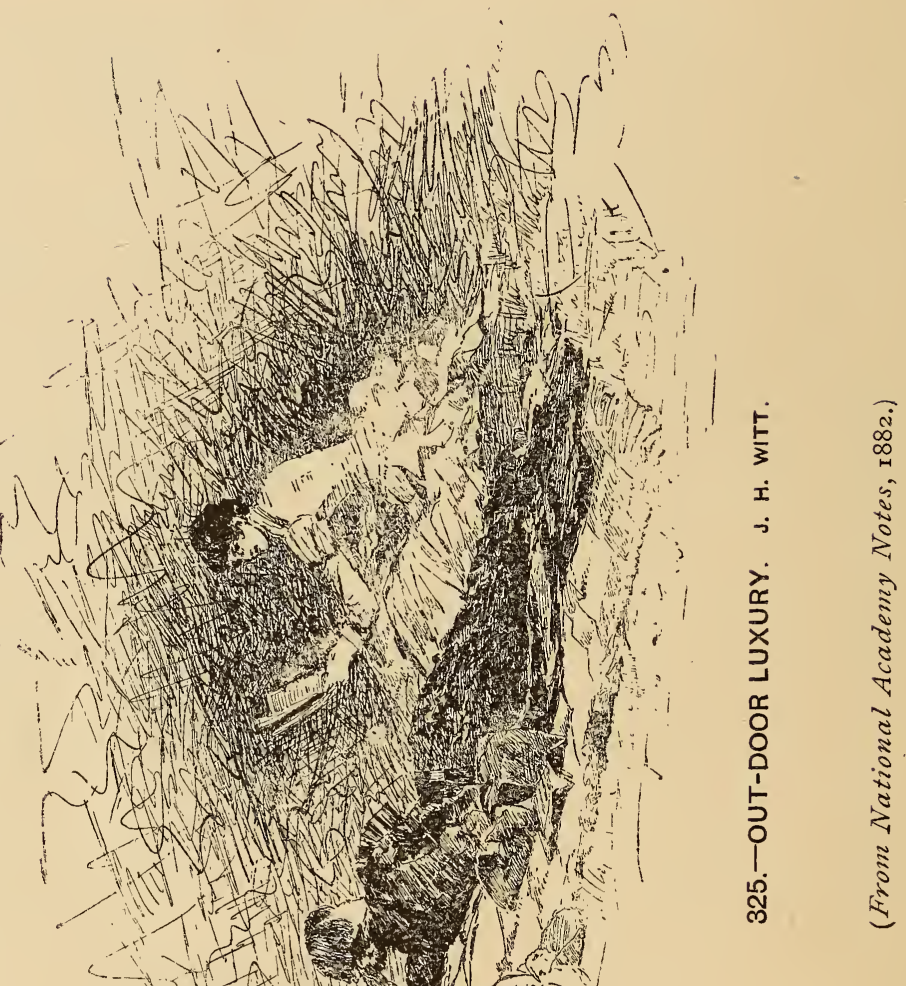


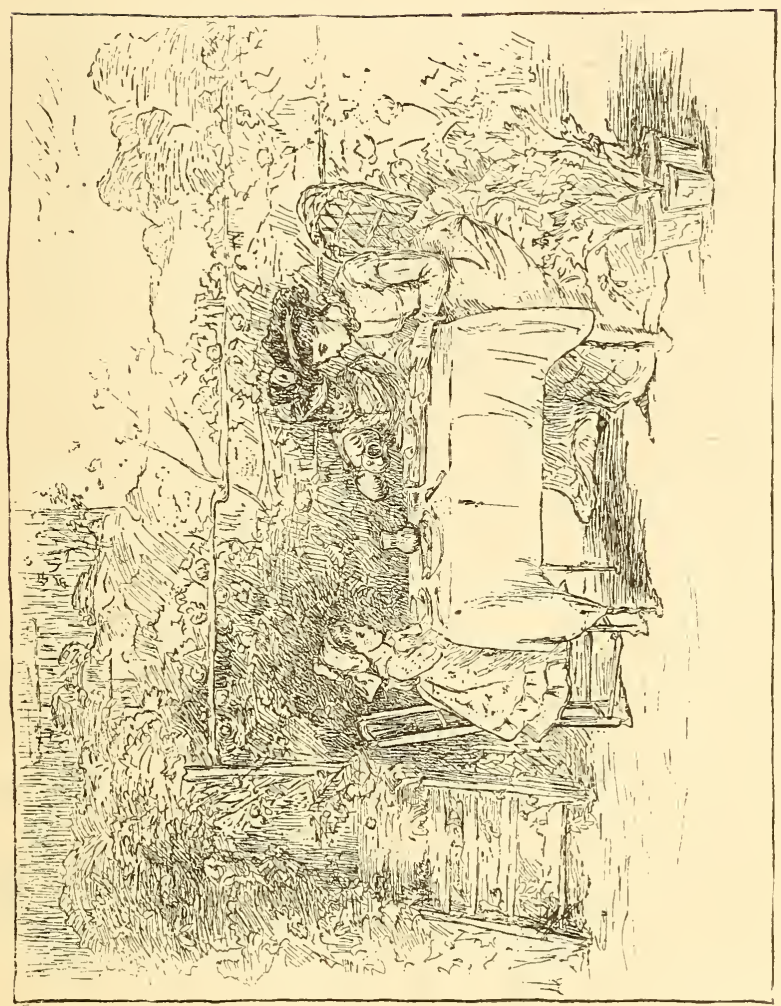




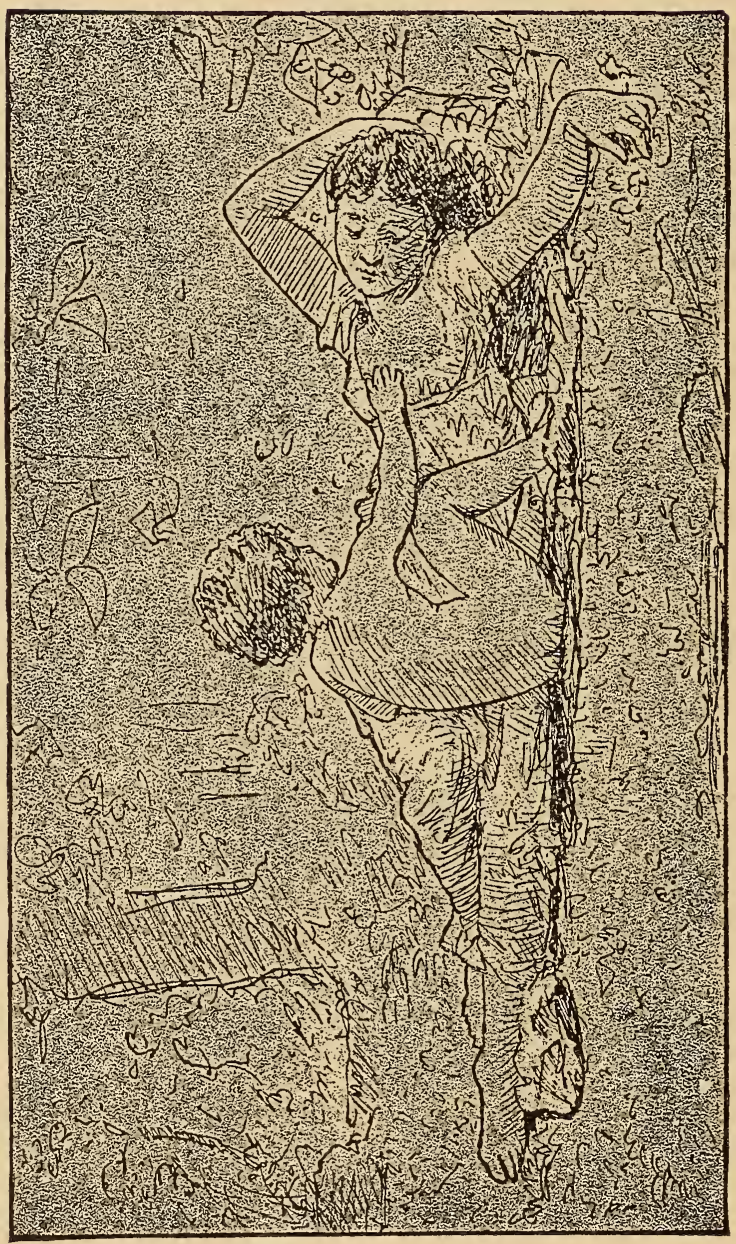




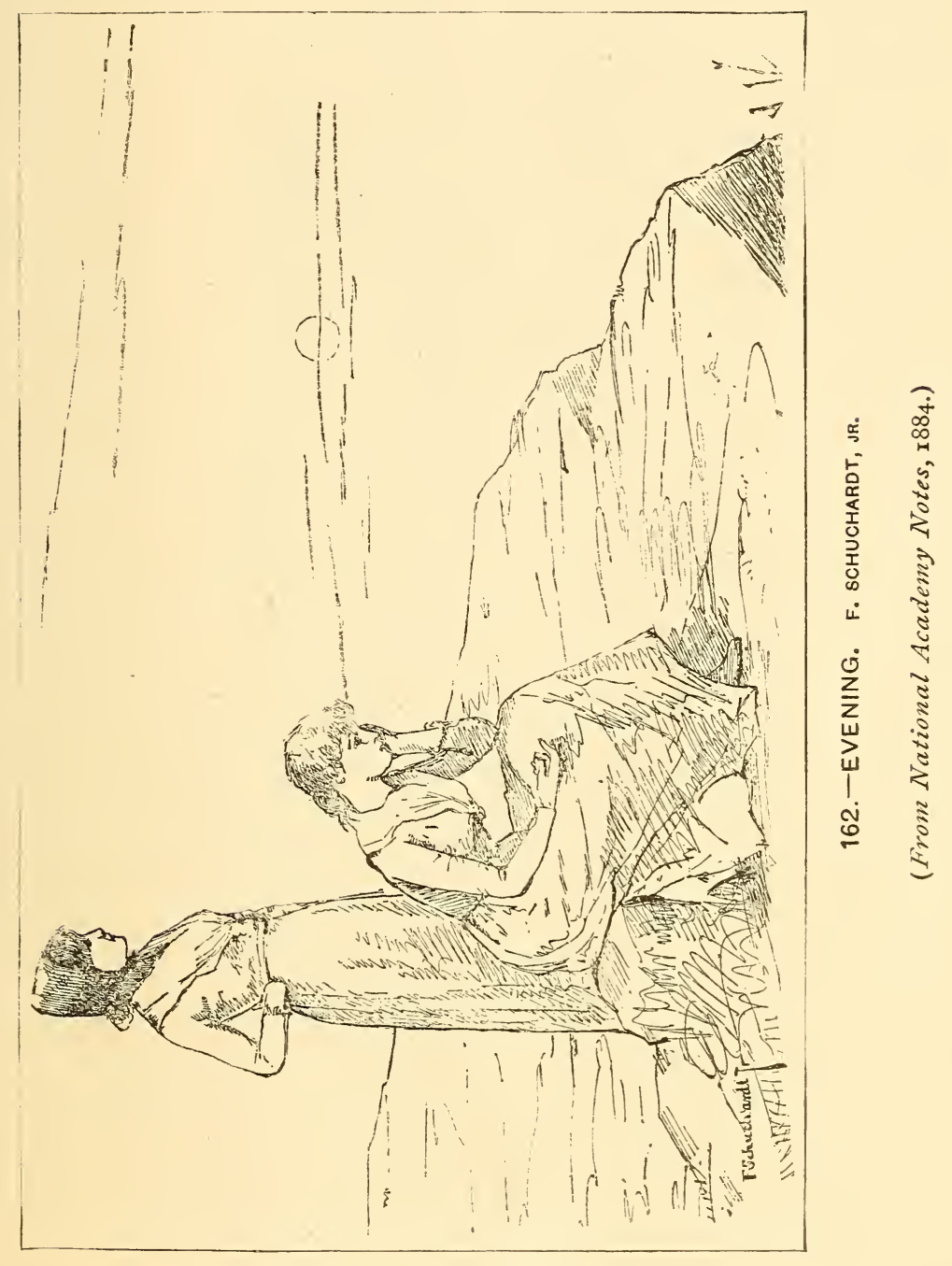




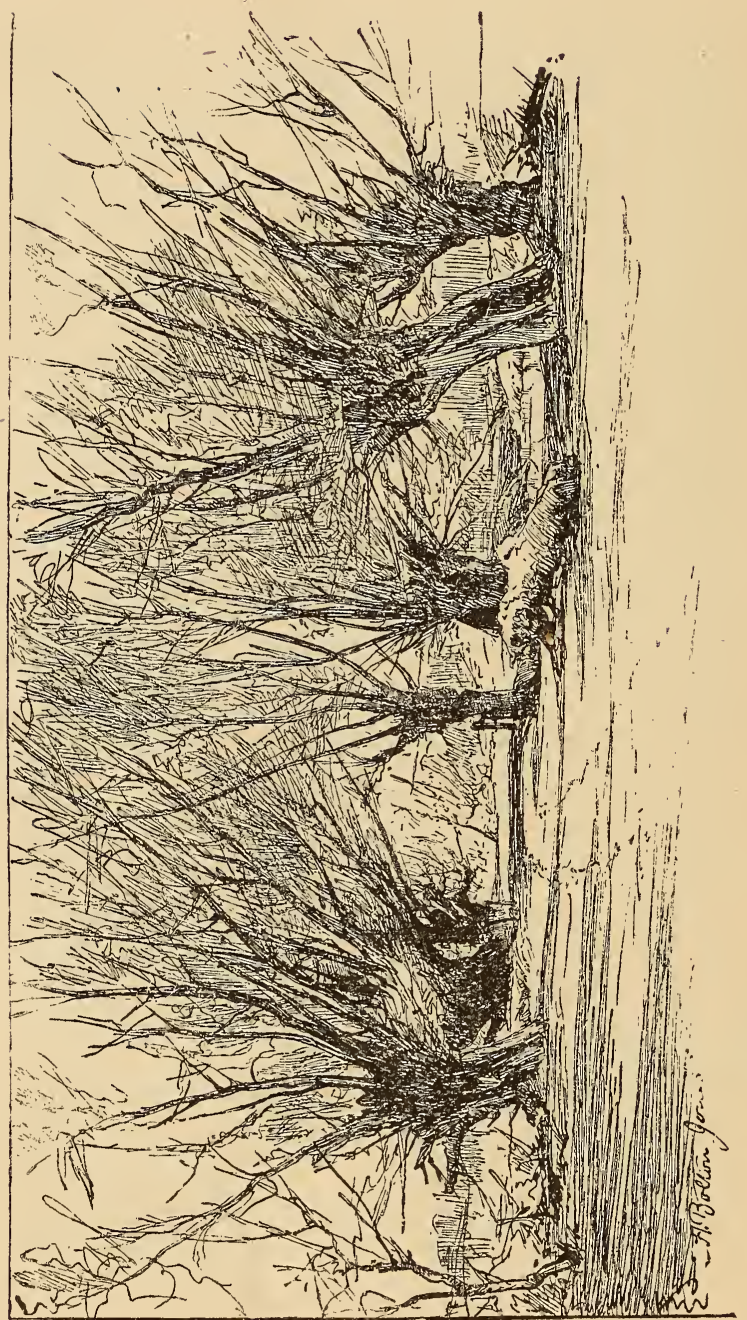




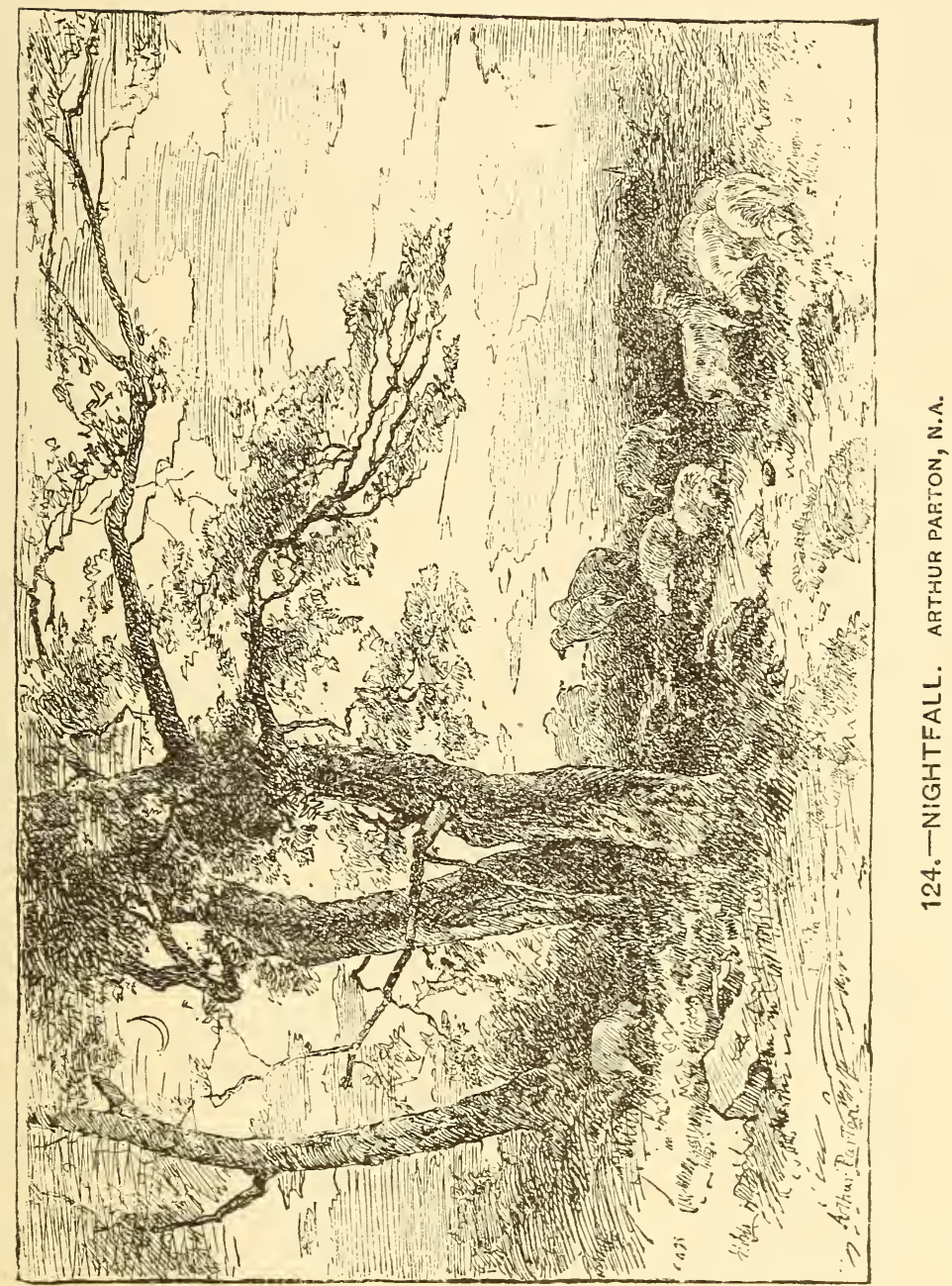




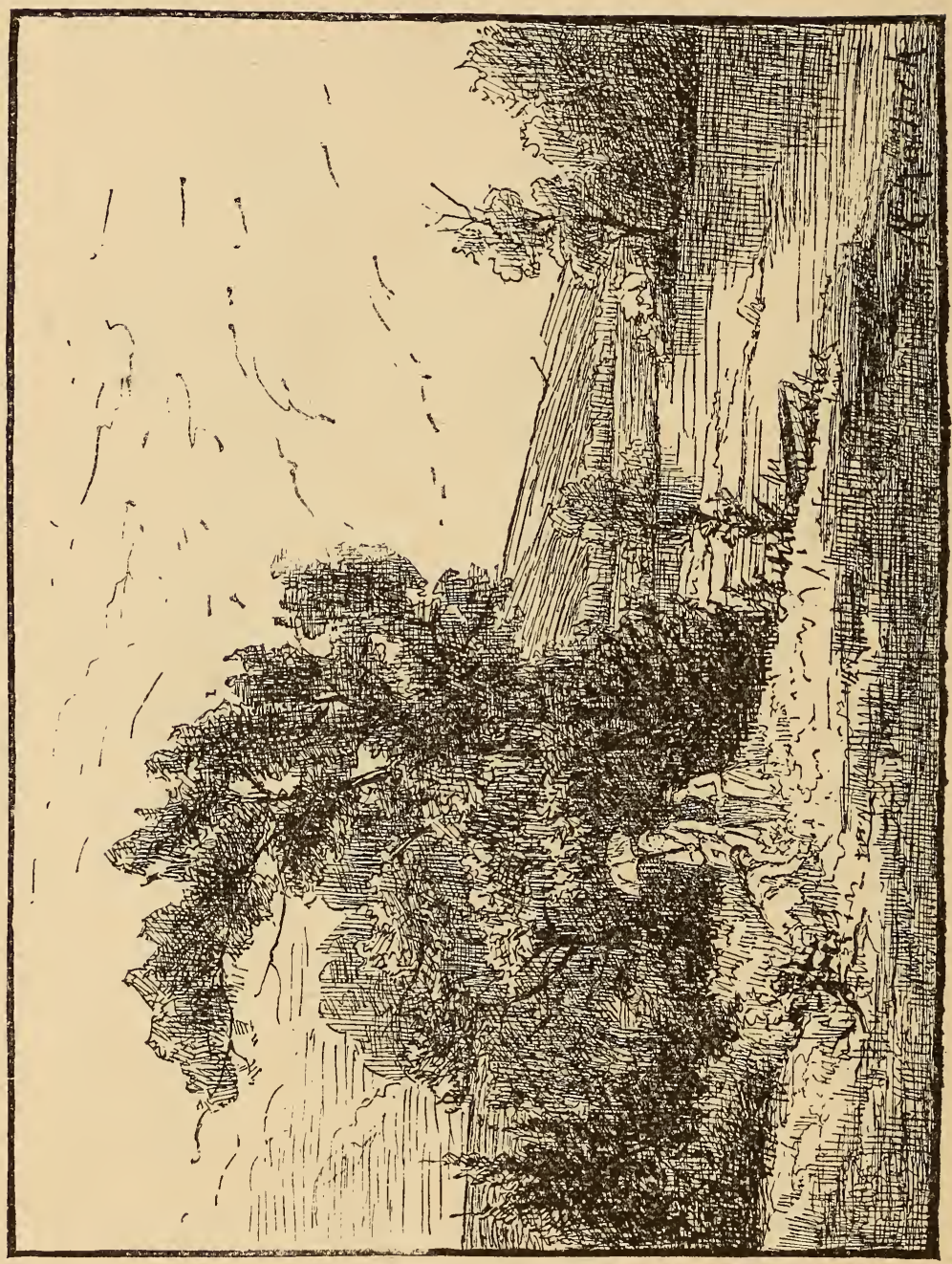




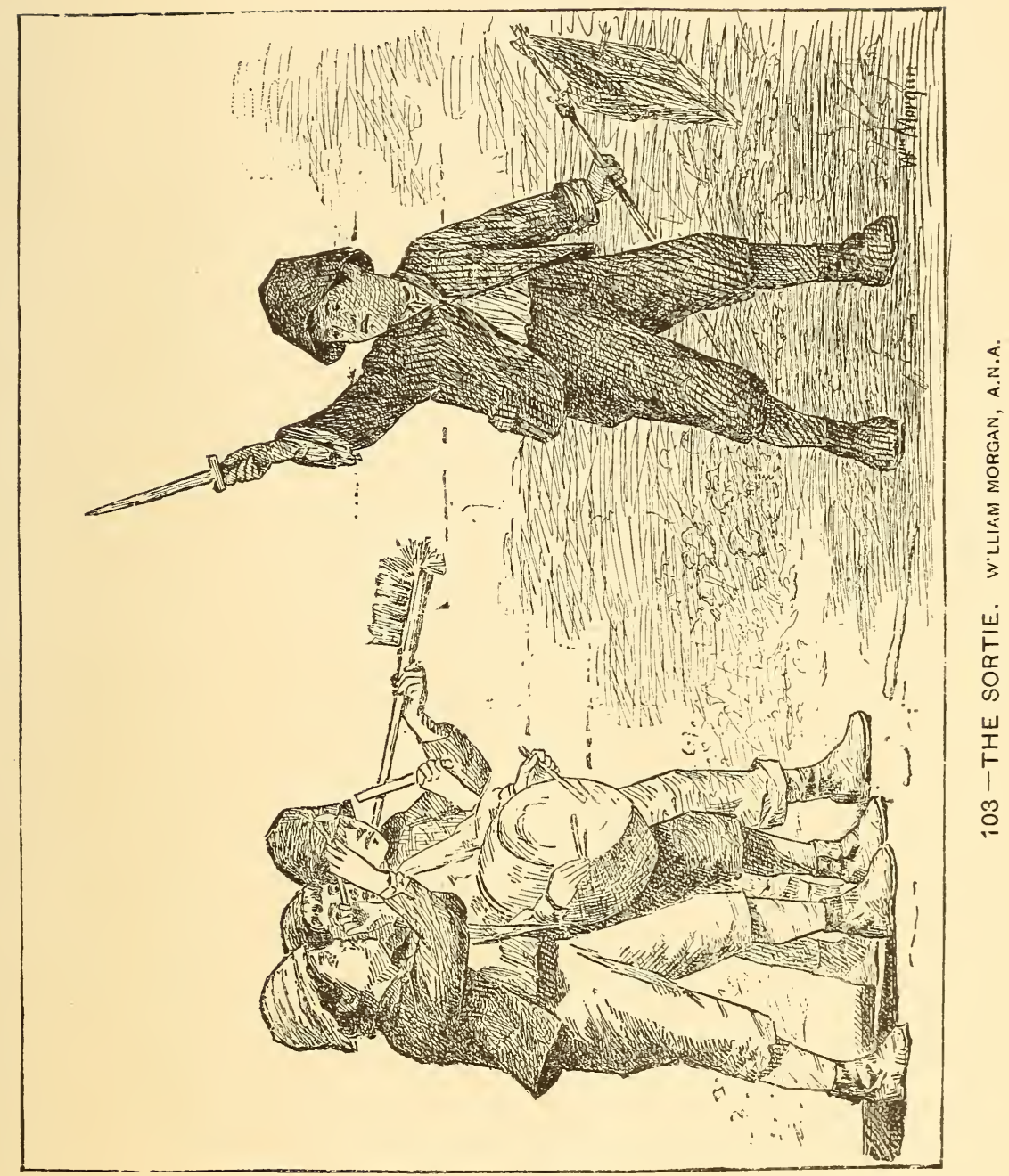




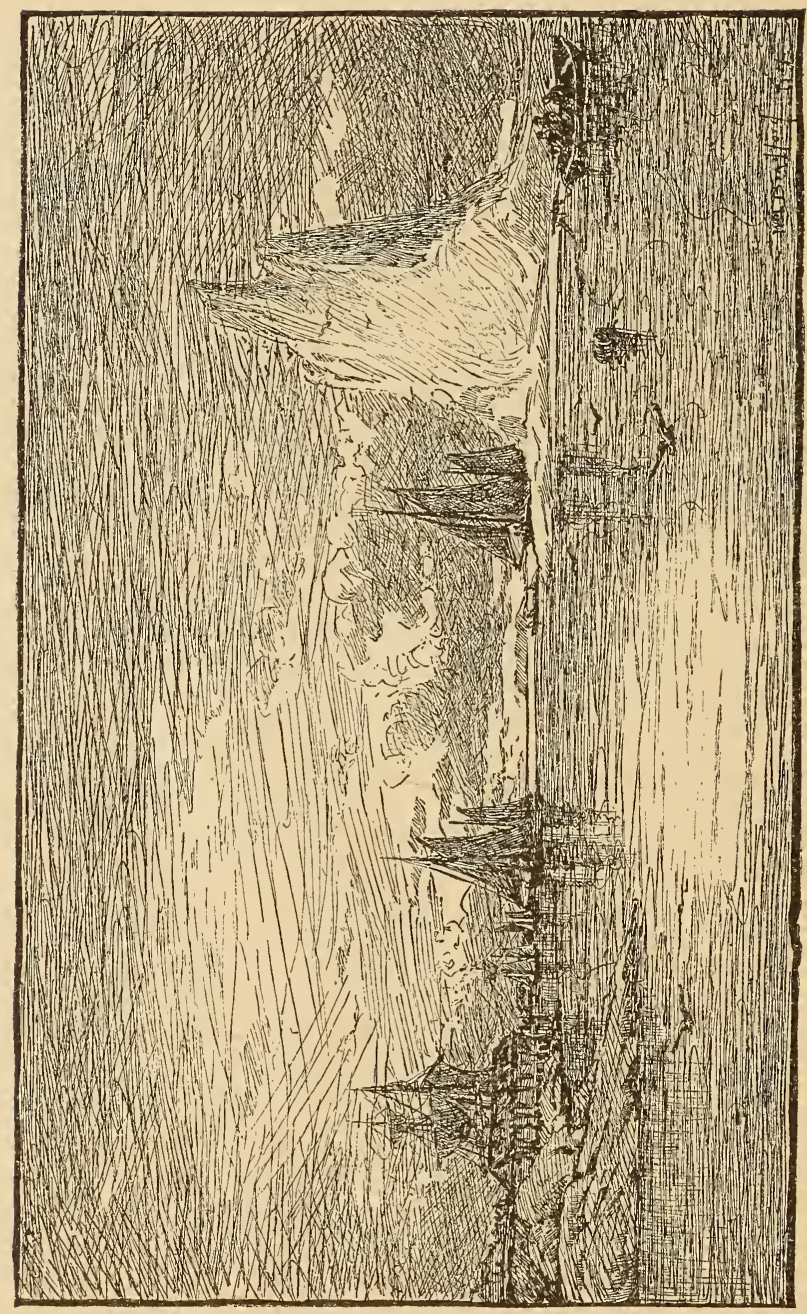

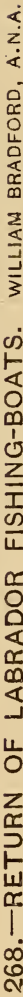


Louisville, Kéntucky', I884.

$x x i$

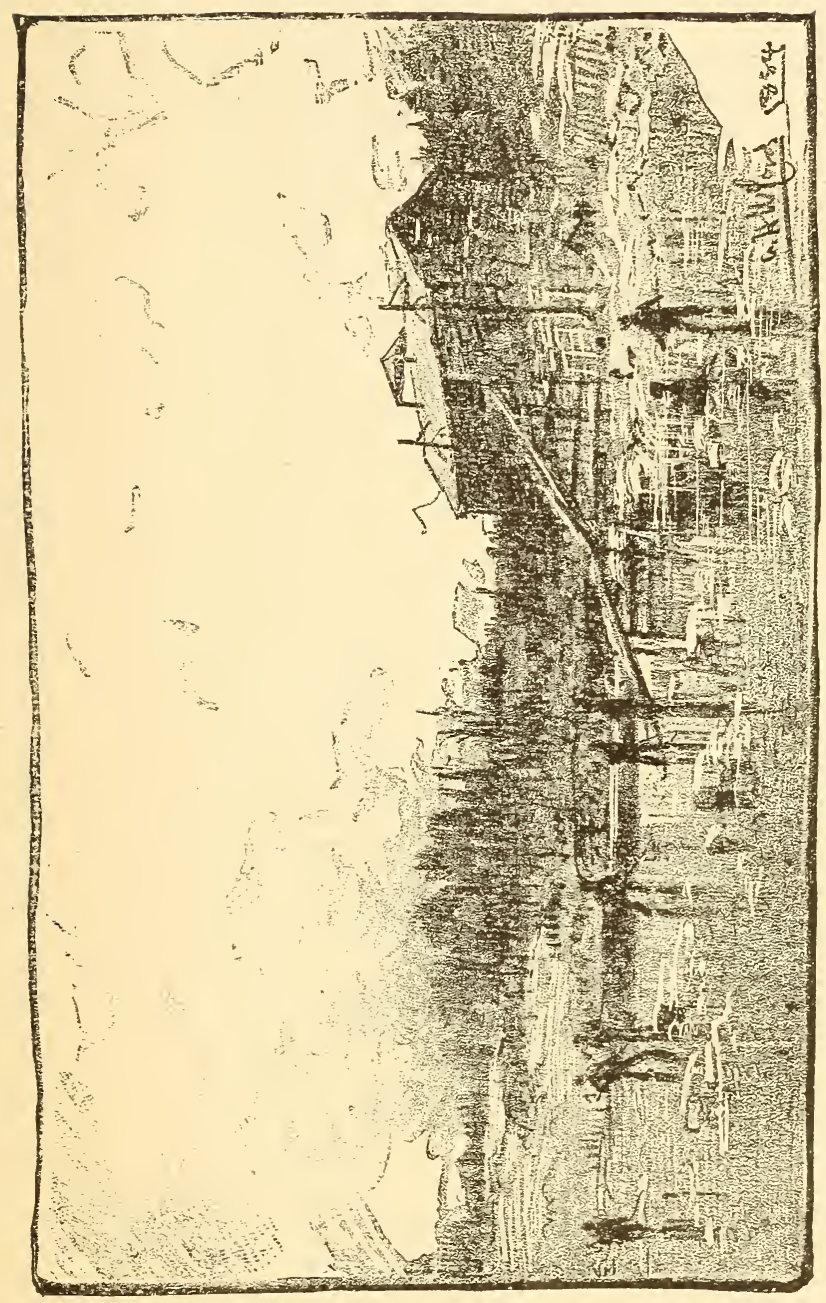

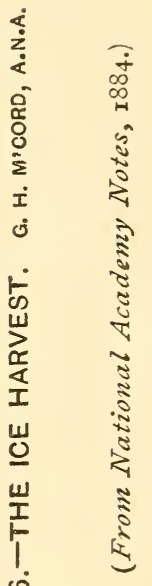

\&ั 


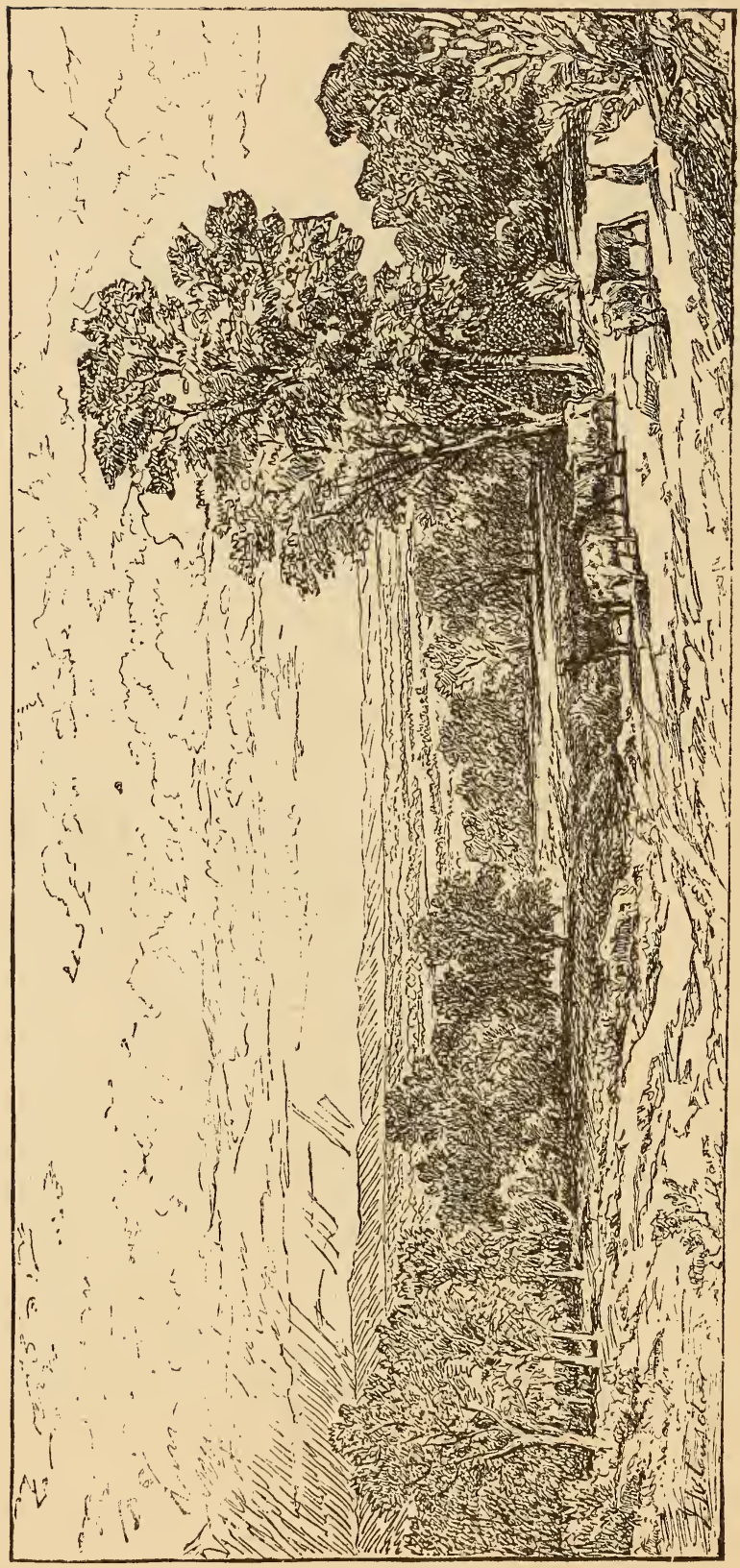

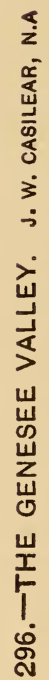




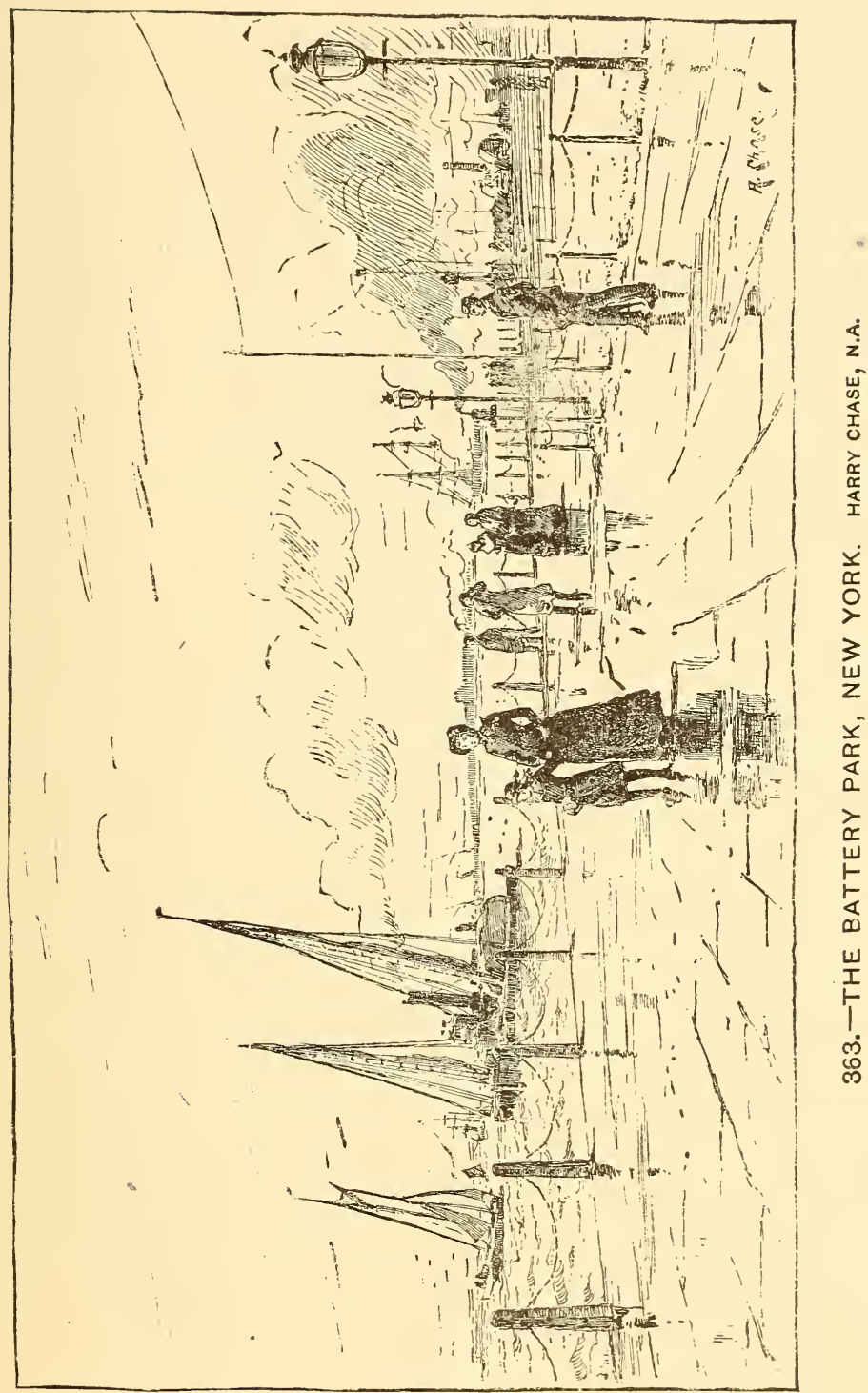




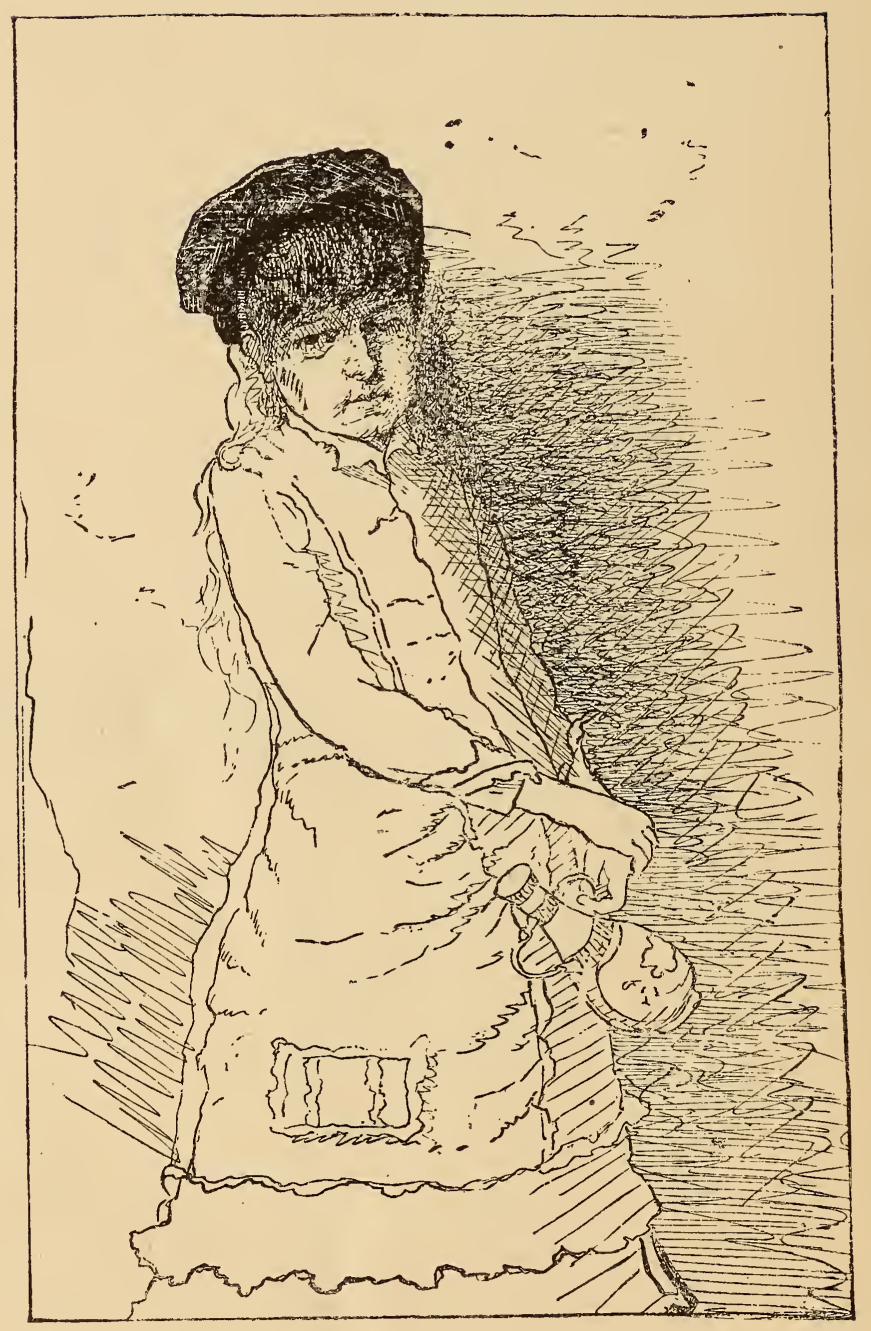

118. -THE BROKEN VASE.

G. H. STORY, A.N.A.

(From National Academy Notes, 1884.) 


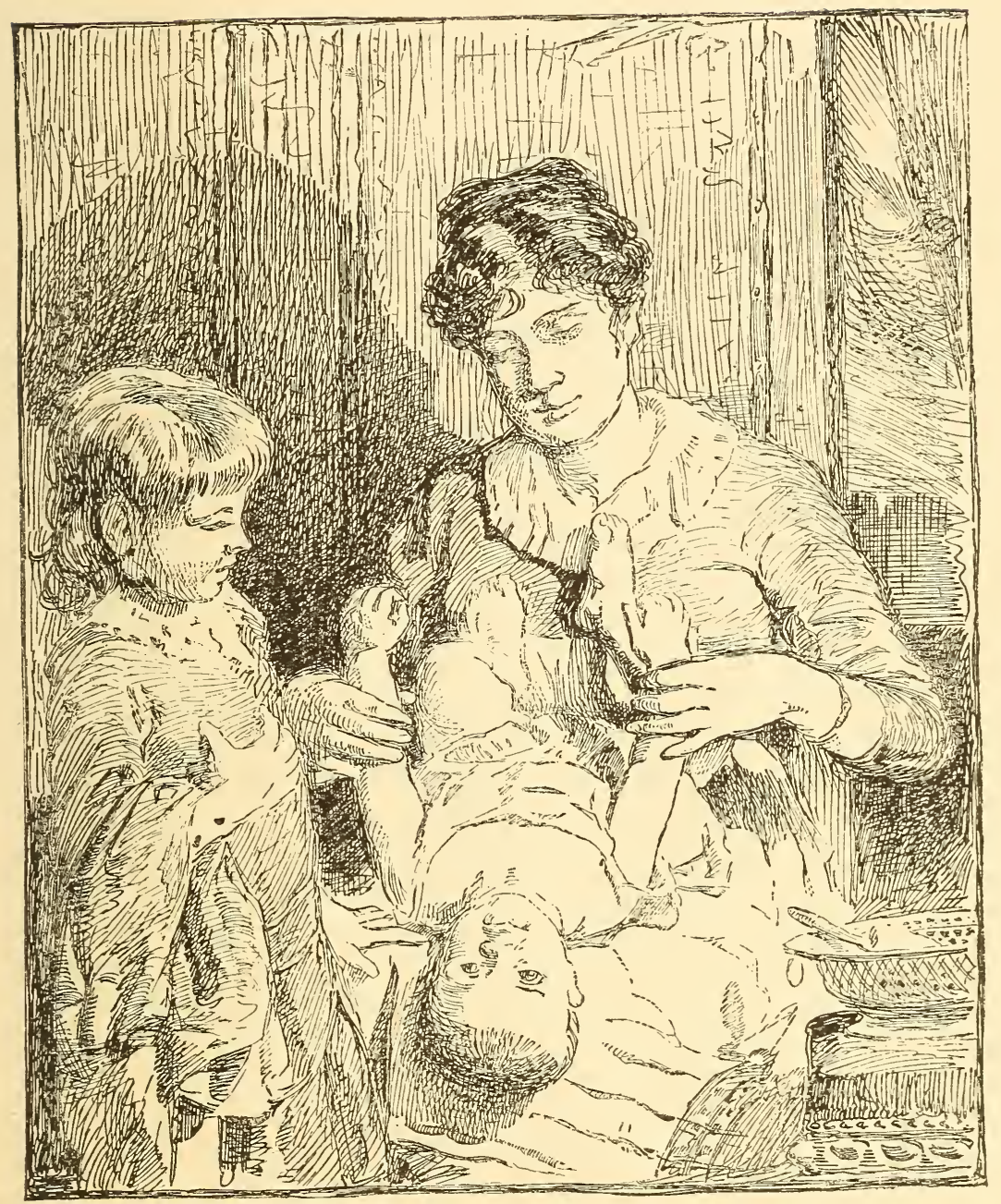

234. - "SEE-SAW MARGERY DAW."

s. J. GUY, N.A.

(From National Academy Notes, 1884.) 


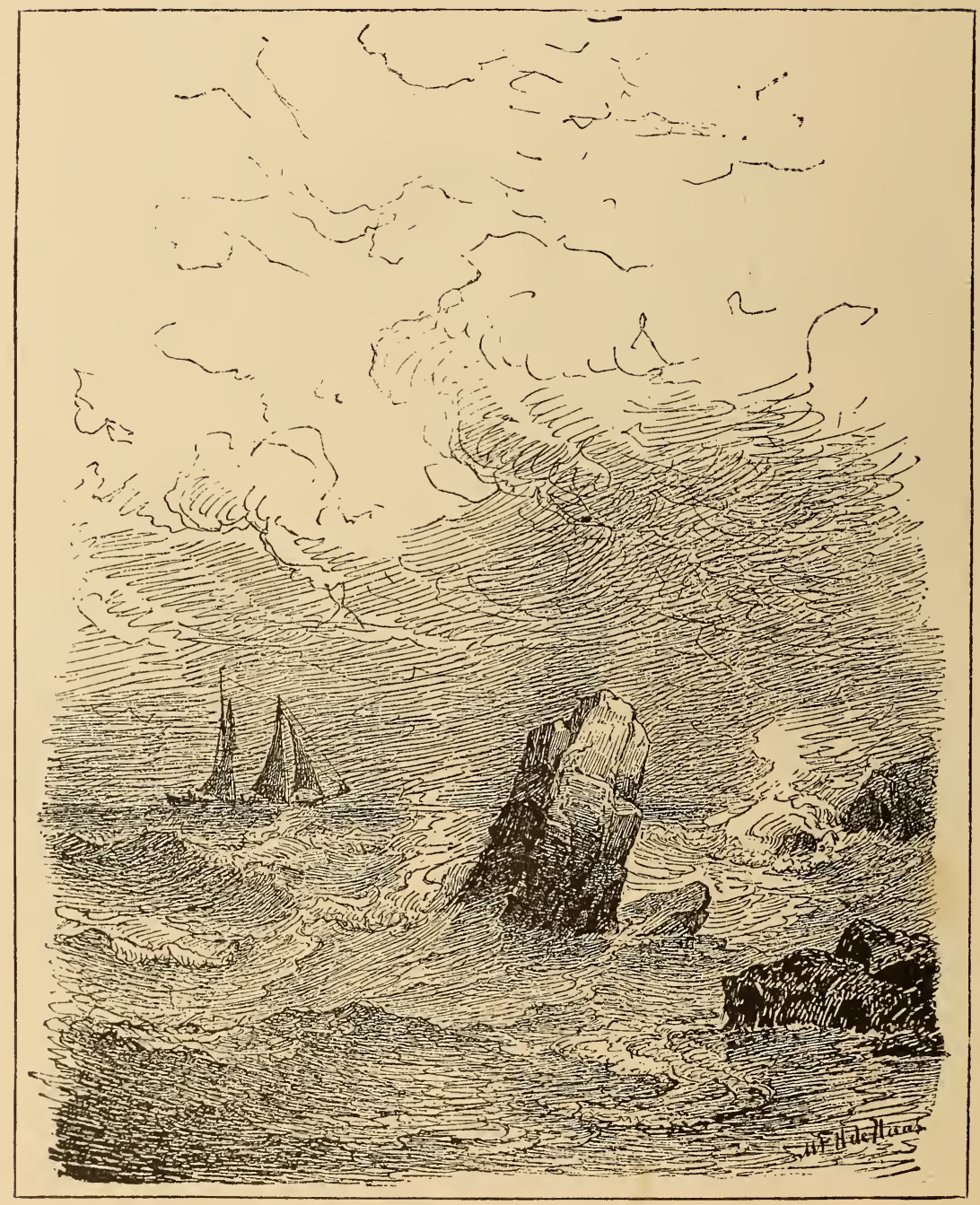

122. - MARBLEHEAD NECK, MASS.

M. F. H. DEHAAS, N.A. 


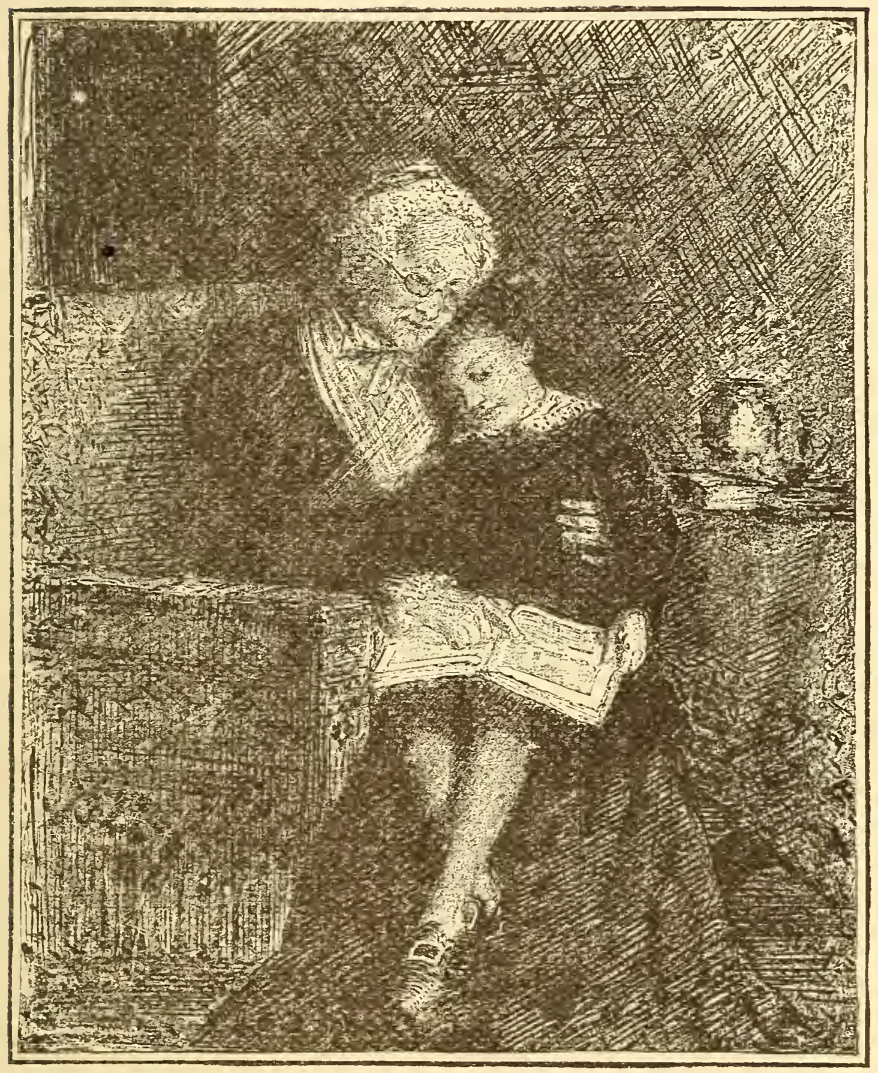

351. - THE STORY BOOK.

E. WOOD PERRY, N.A. 


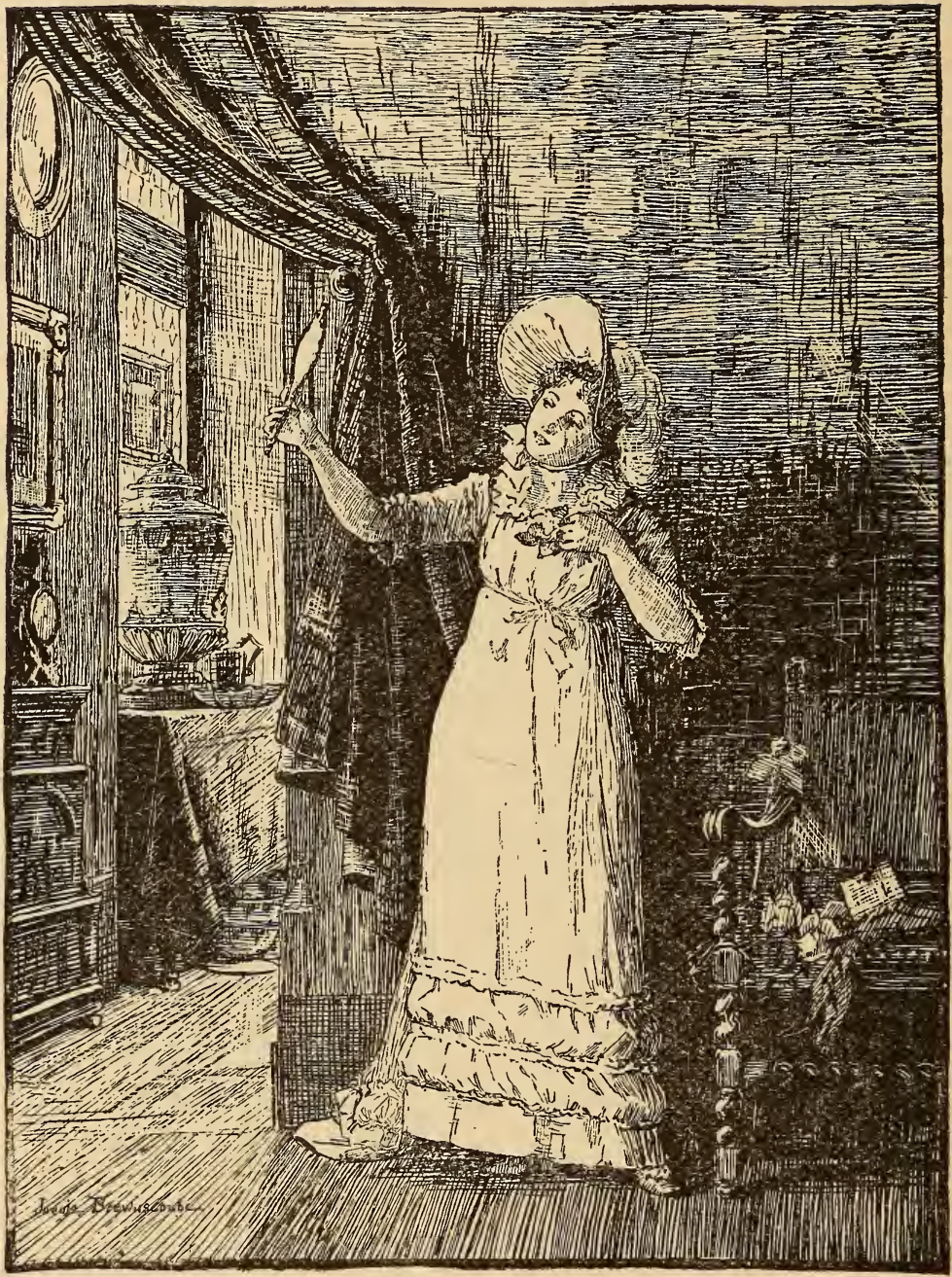

114. -THE LAST LOOK.

JENNIE BROWNSCOMBE.

(From National Academy Notes, 1884.) 


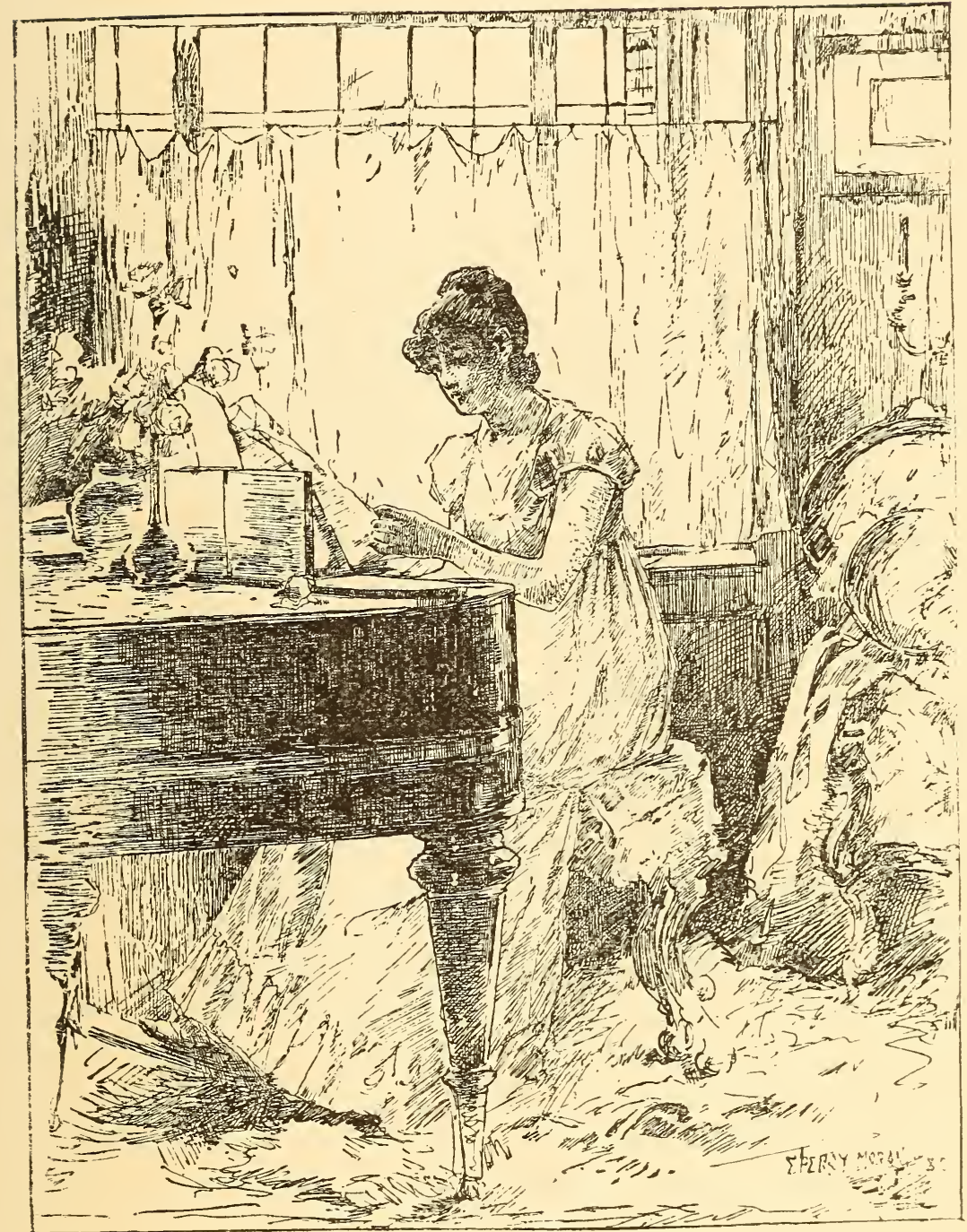

326.-AN OLD-TIME MELODY.

PERCY MORAN.

(From National Academy Notes, I884.) 


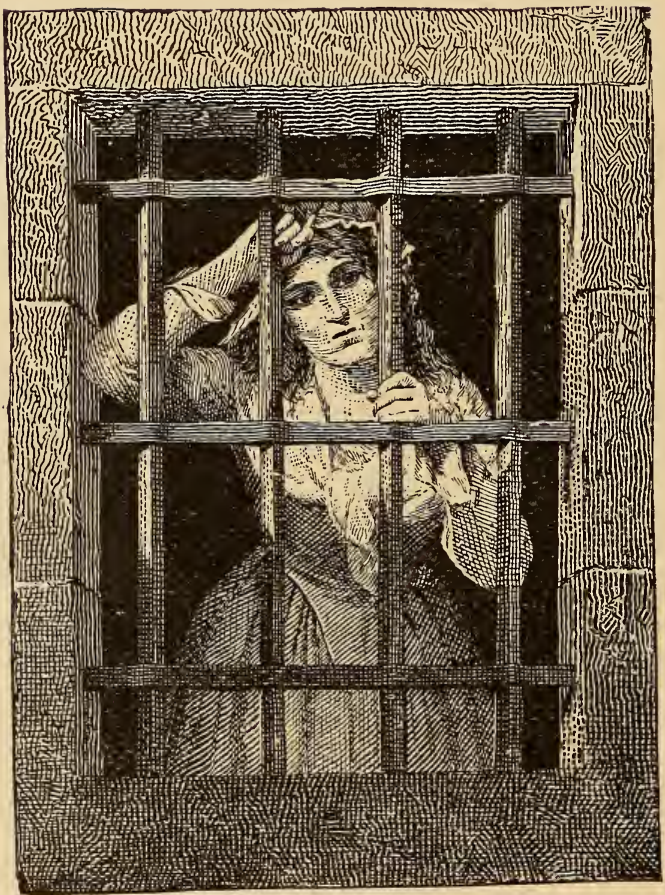

67.-CHARLOTTE CORDAY IN PRISON.

WILLIAM M'LEOD, AFTER C. L. MULLER. 


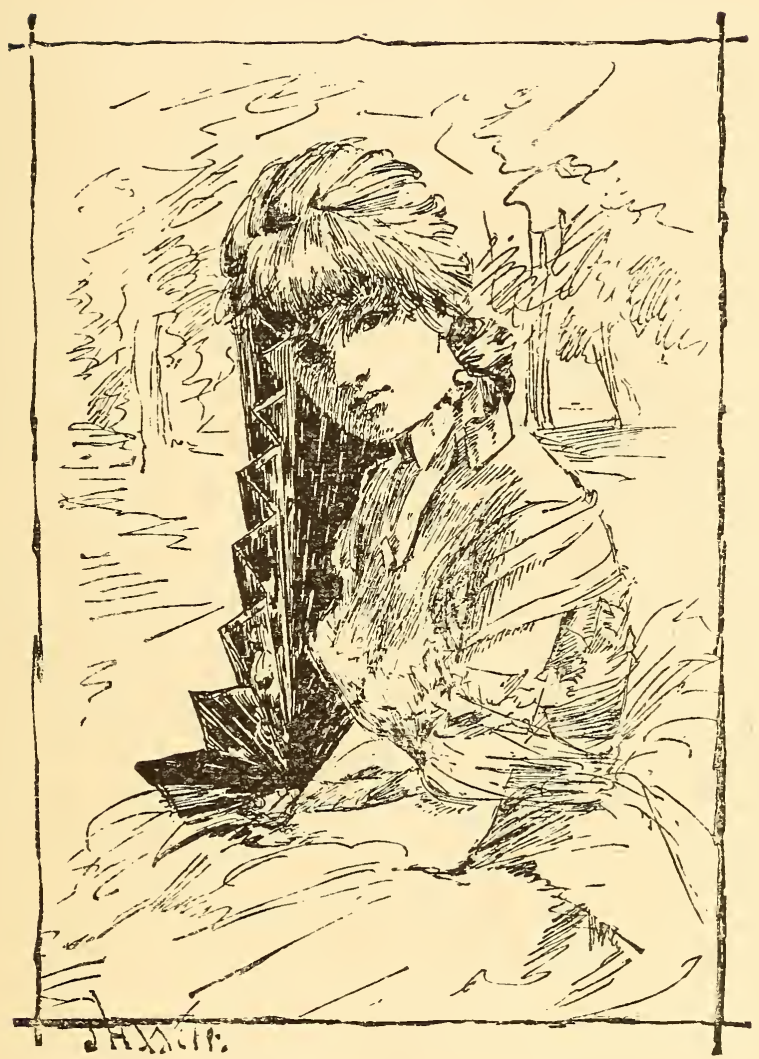

134.-AT HOME.

J. H. WITT. 


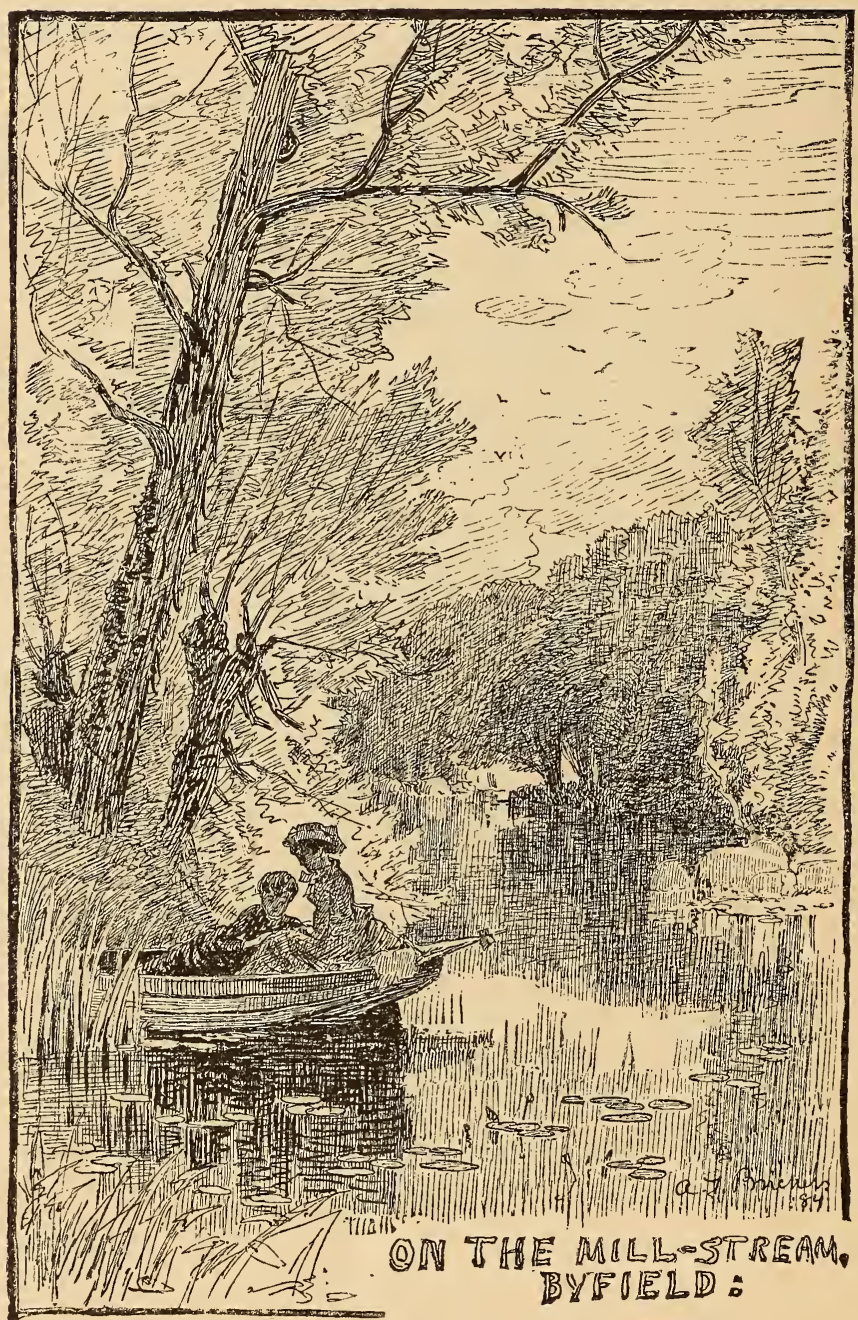

246. -ON THE MILL STREAM.

A. T BRICHER, A.N.A. 


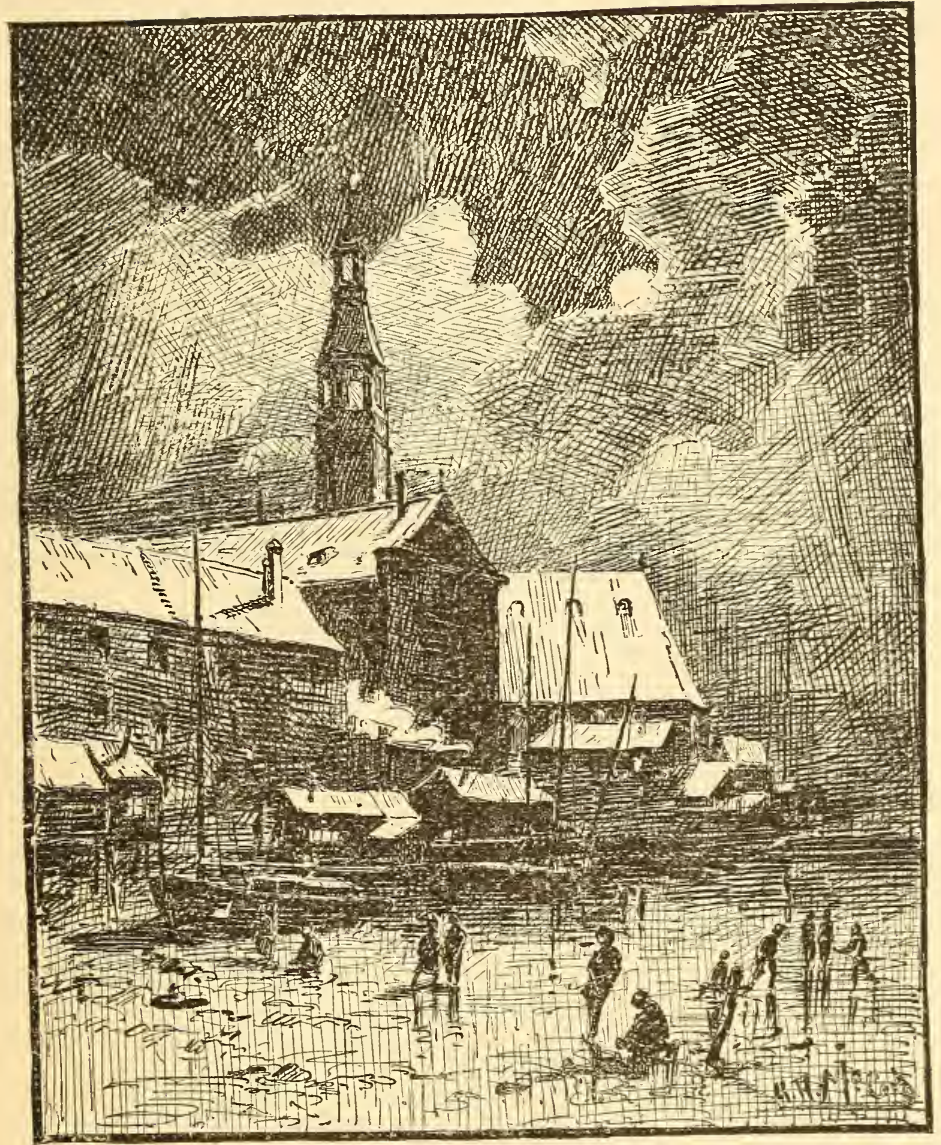

381. -THE BON SECOURS MARKET MONTREAL.

G. H. M'CORD, A.N.A.

From National Academy Notes, 1882. 


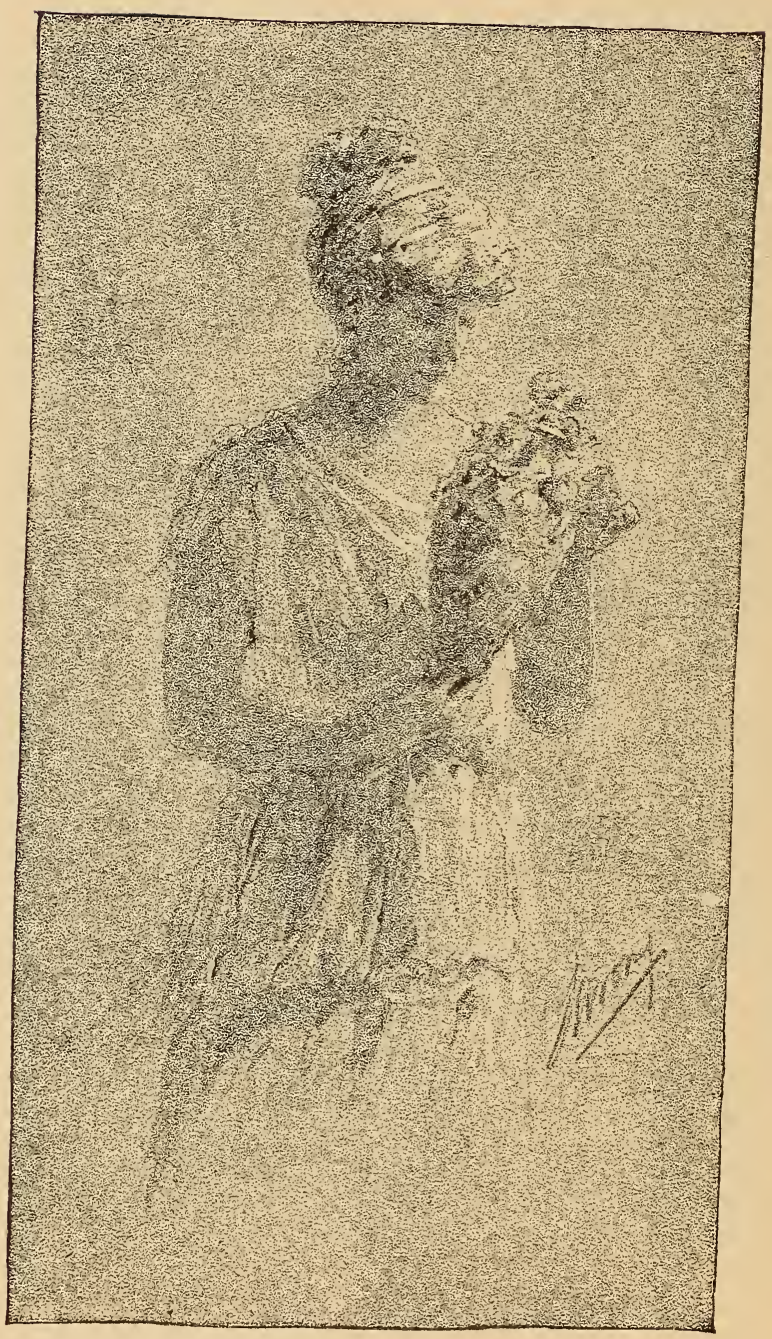

1.-A CONNOISSEUR.

N. SARONY. - 


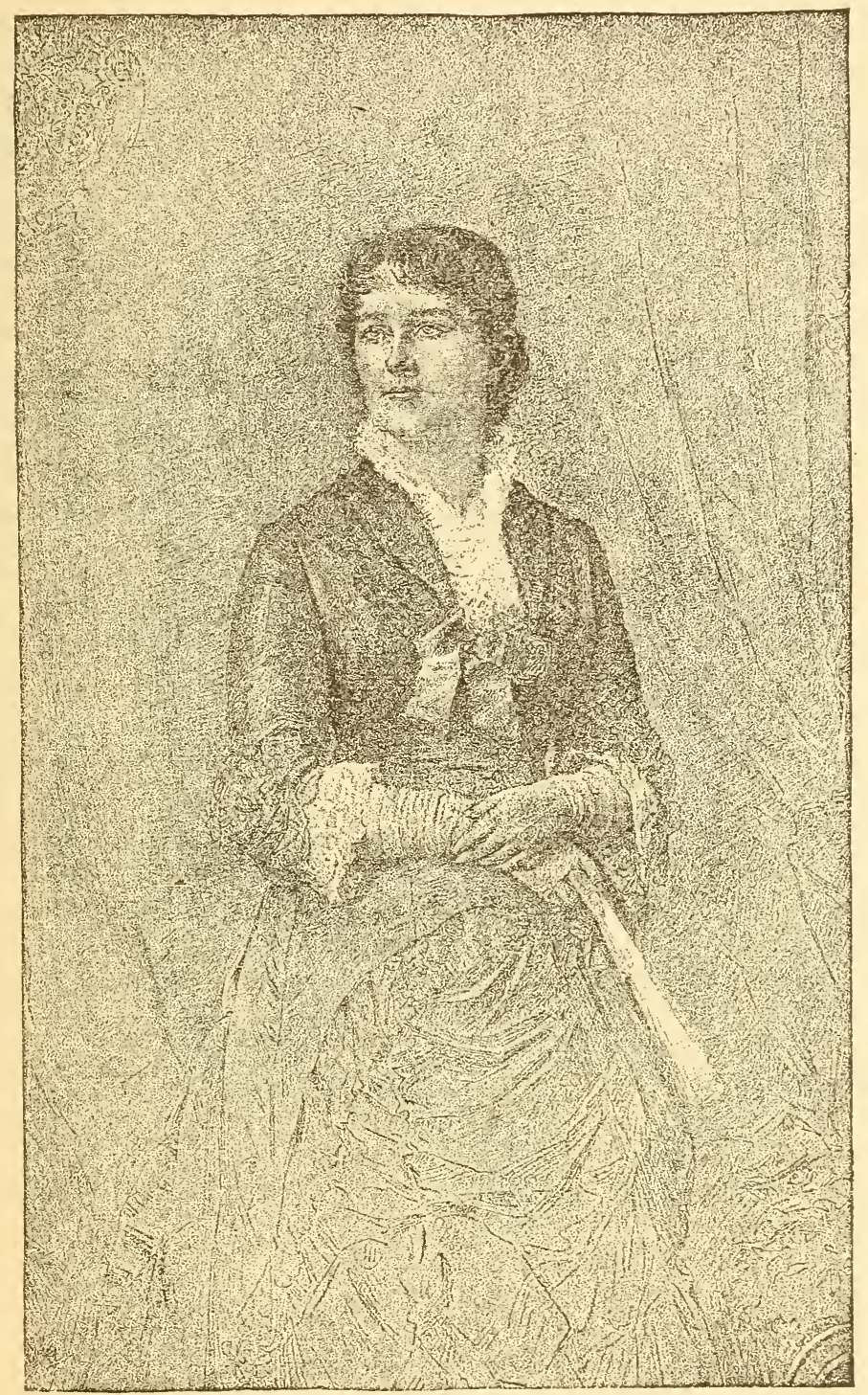

311.-PORTRAIT OF A LADY.

CARL L. BRANDT, NA.

(From National Academy Notes, 1883.) 


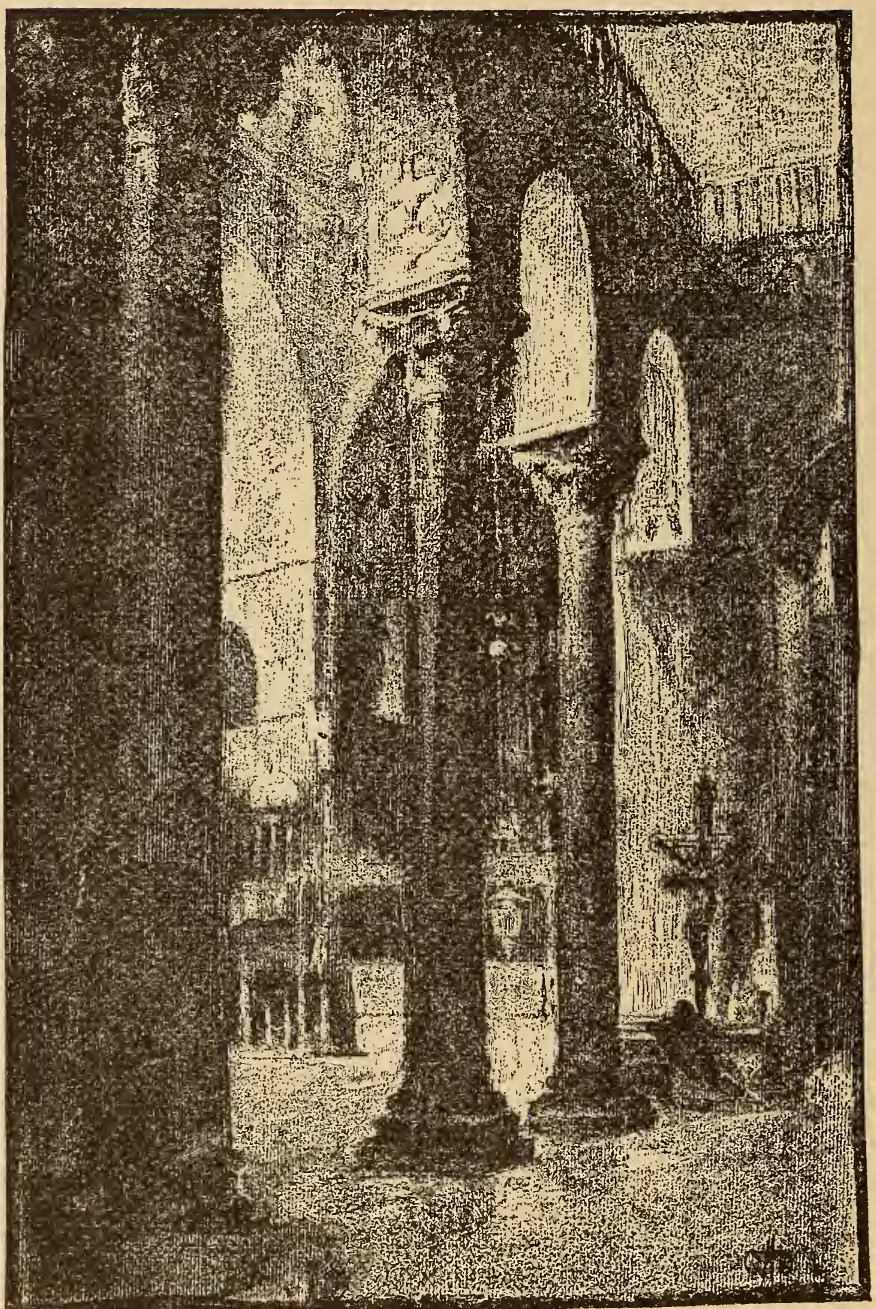

133.-INTERIOR OF ST. MARK'S, VENICE.

OTTO H. BACHER.

(From National Academy Notes, 1884.) 


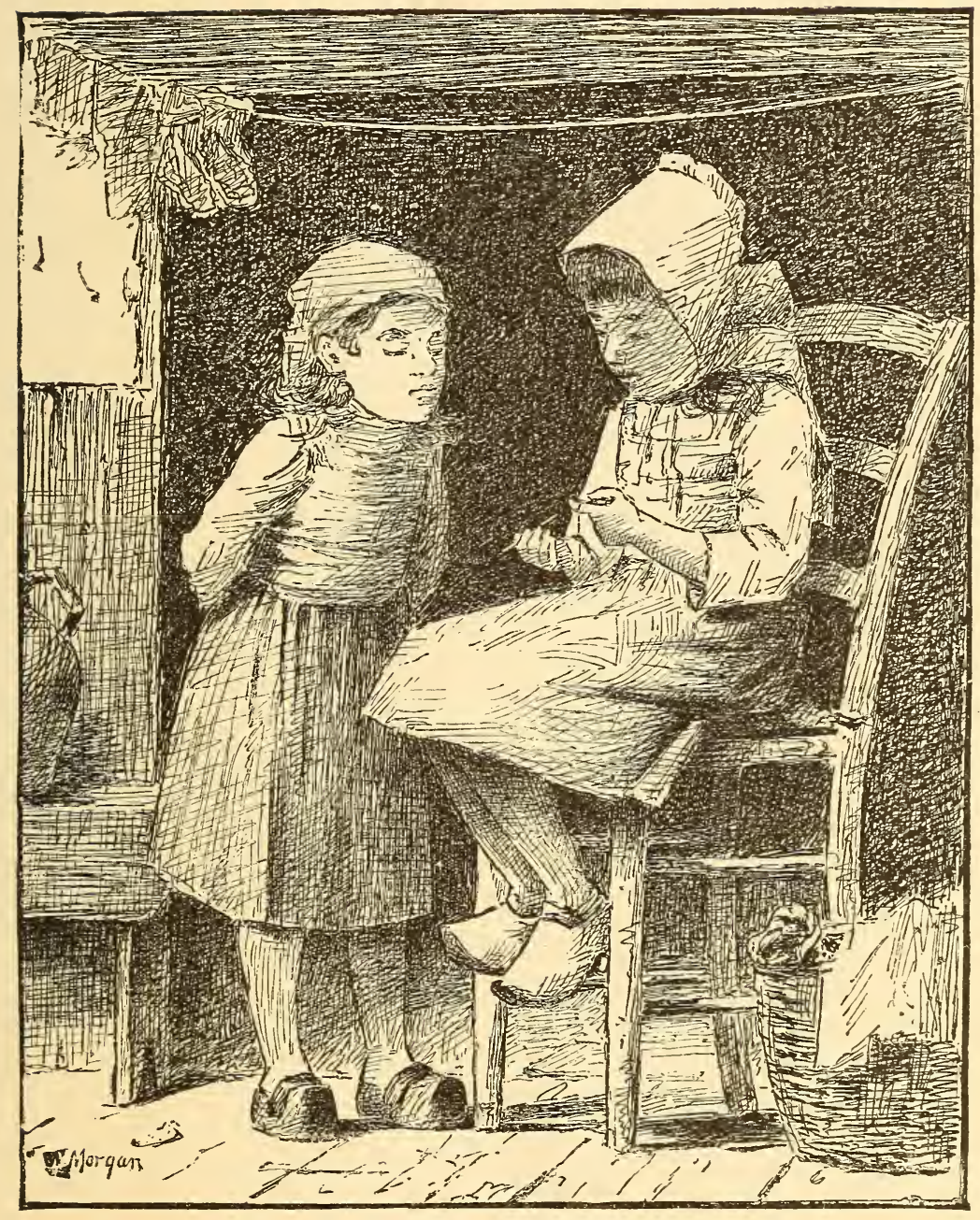

402.-THE KNITTING LESSON.

WILLIAM MORGAN, A.N.A. 


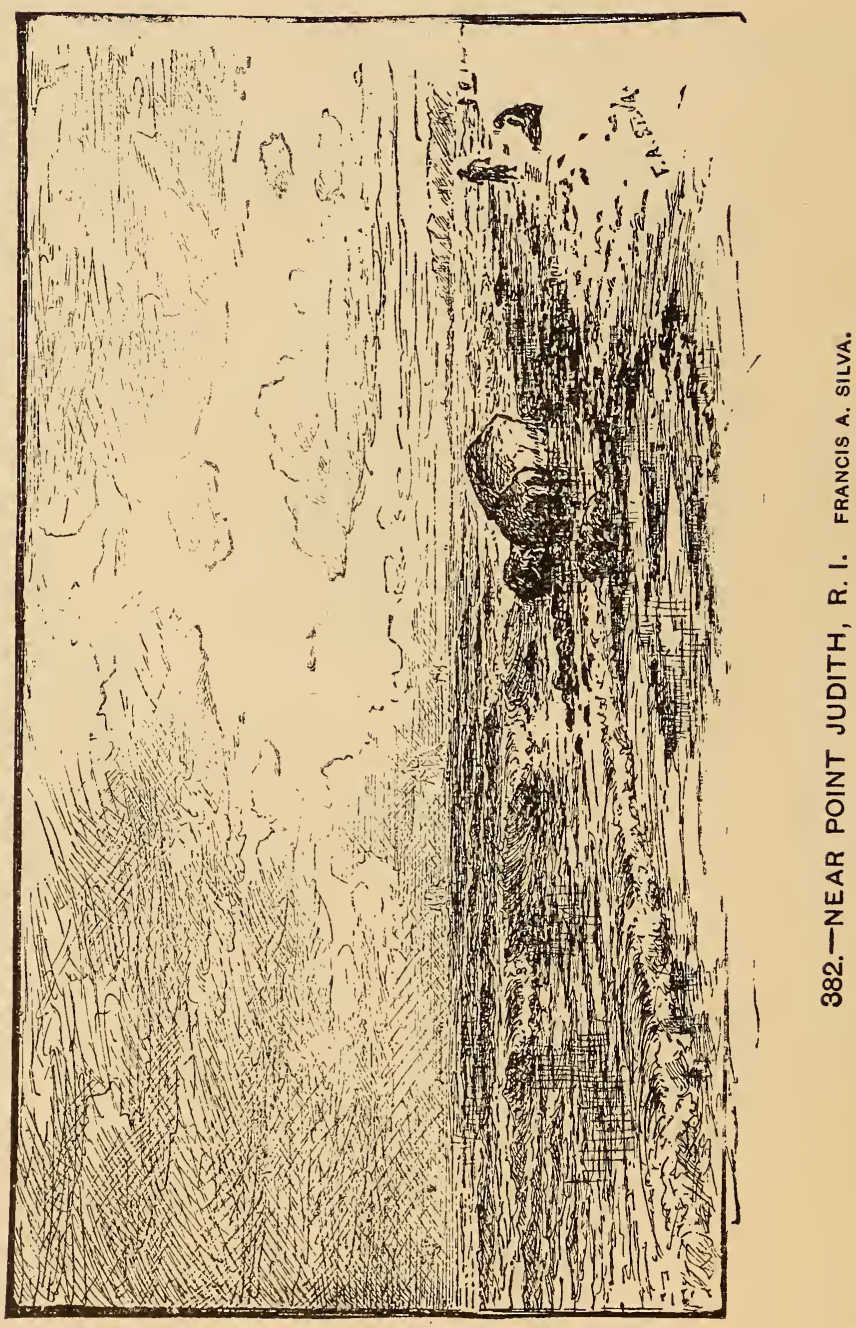




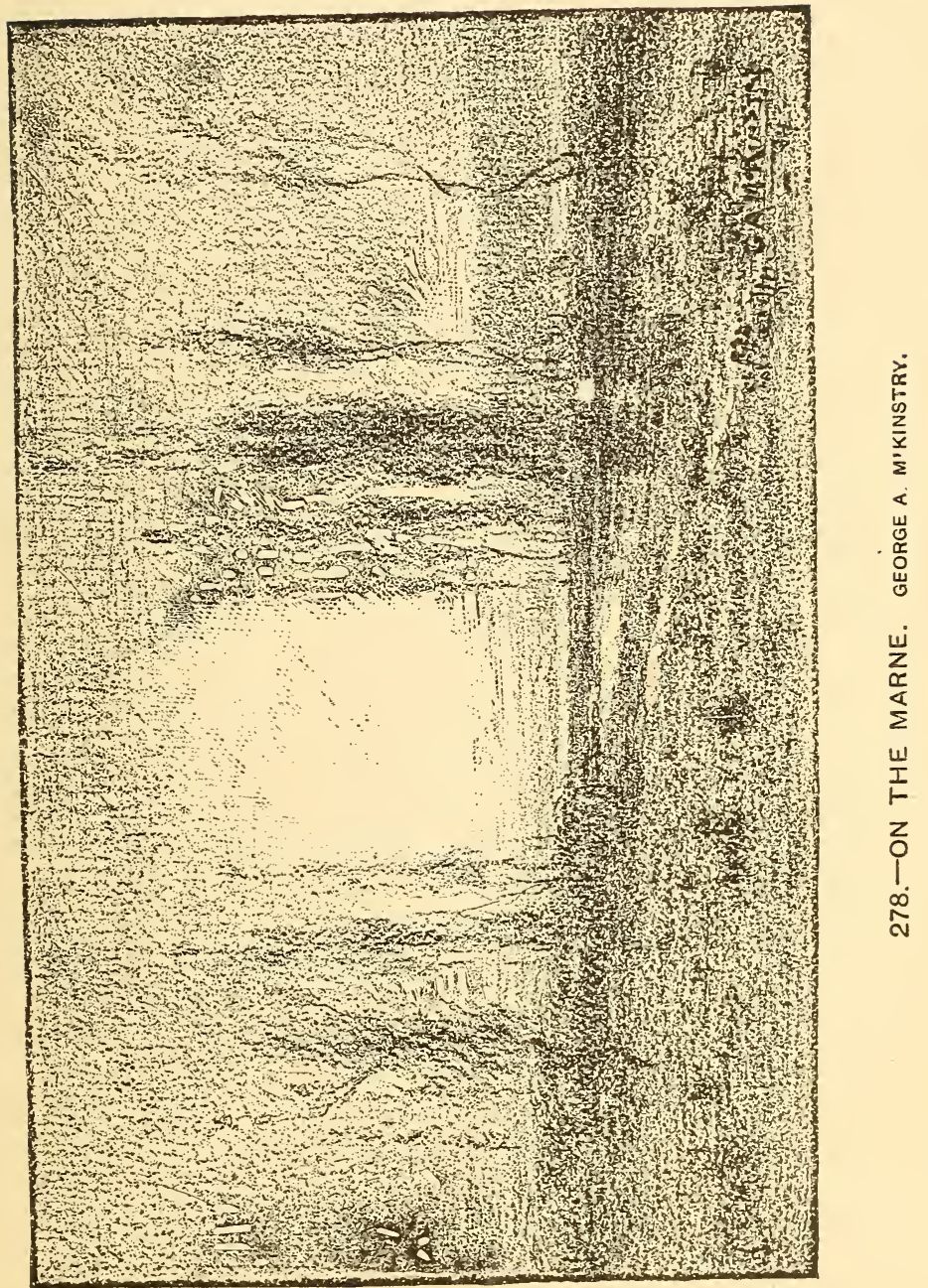




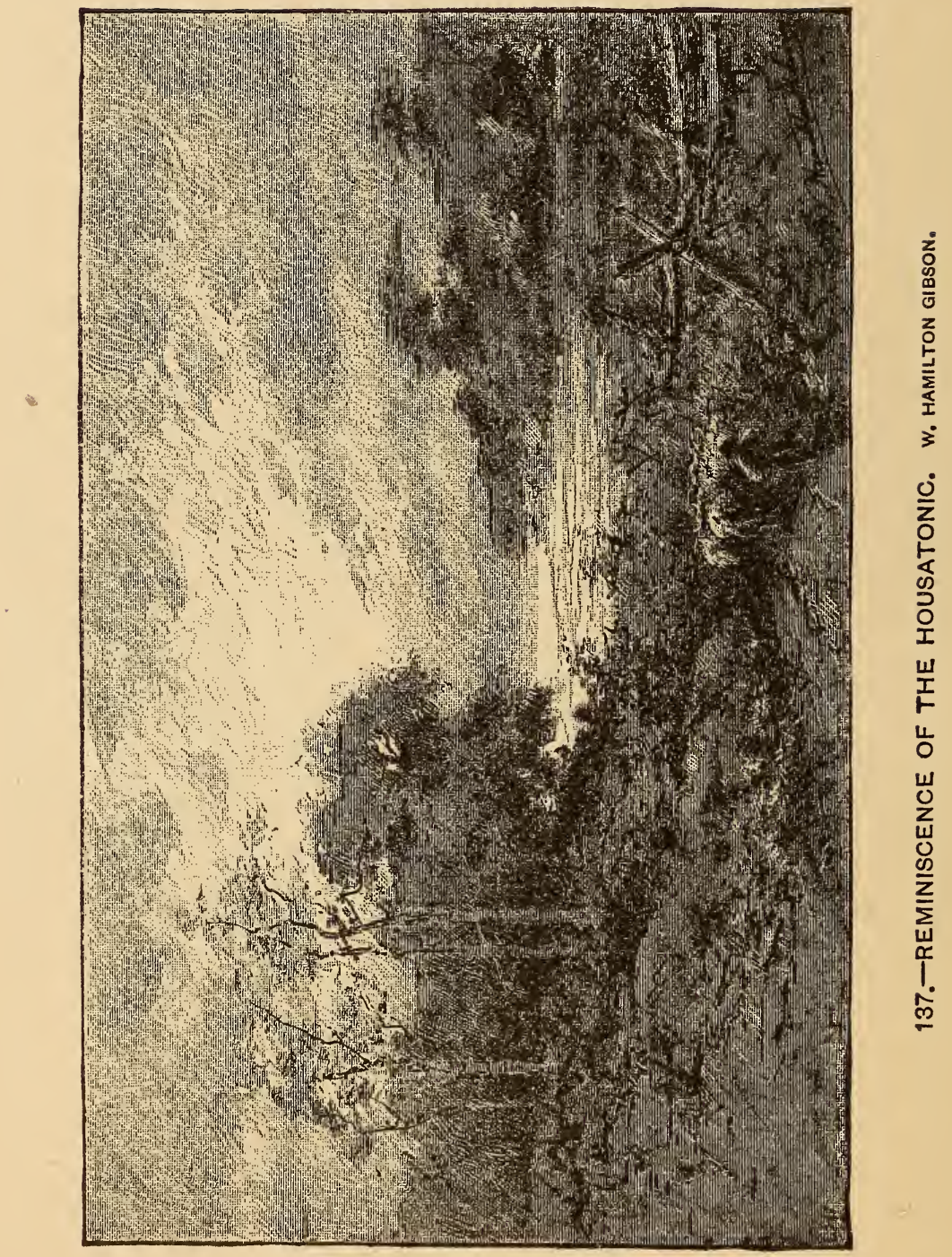




\section{LIST OF ILLUSTRATIONS.}

No. ARTIST.

133. Bacher, Otto H

268. BRADFORD, WILliaM

3it. Brandt, Carl L...

71. Brenner, Carl C

246. BRICHER, A. T

II4. BROWNSCOMBE, J

296. Casilear, J. W

363. Chase, HarRY

375. Conant, C. W

83. DE HaAs, M. F. H..

122. DE HAAs, M. F. H

427. Gaul, Gilbert.

I37. Gibson, W. Hamilton.

234. Guy, Seymour J

I30. Johnson, Eastman

256. Jones, H. Bolton...

378. Kollock, M

323. LOOP, HENRY A.

38r. McCord, G. H.

206. McCorD, G. H.

278. McKinstry, Geo. A

67. M'LeOd, W. (after Muller).

326. Moran, PERCY...

IO3. MORgan, WilliaMi

402. Morgan, William.

I24. Parton, Arthur.

35I. PERry, E. WOOD...

I. SARONY, N

3. SARONY, N

I62. SCHUCHARDT, F., JR

203. Shirlaw, Walter.

382. Silva, F. A

II8. Story, G. H.

270. Tojetti, Vergilio..

iro. Tojetti, Vergilio.

I34. WIтT, J, H

325. WitT, J. H.

339. Wyant, A. H
SUBJECT.

PAGE. .Interior of St. Mark's.................xxxvi

Labrador Fishing Boats...................xx

Portrait of a Lady .......................xxxv

Through the Clearing........................

On the Mill Stream......................xxxii

The Last Look..........................xxviii

The Genesee Valley.......................xxii

Battery Park, New York..............xxiii

Aftcrnoon Tea...........................xiii

.A Fresh Brecze...............................xi

.Marblchead Neck.........................xxvi

Silenced.......................................vii

Effect on the Housatonic...................xl

"See Saw, Margery Daw" "............xxw

The Funding Bill.......................viii

Through the Willows .....................xvi

Gathering Wild Flowers...............xviii

The Awakening............................xiv

.Bon Secours Market..................xxxiii

The Ice Harvest...........................xxi

On the Marne..............................xxxix

Charlotte Corday ..........................xxx

An Old-Time Melody .....................xxix

A Sortie..................................... xix

The Knitting Lesson .. ..............xxxvii

Nightfall.......................................xvii

The Story Book.........................xxvii

A Connoisse ur.......................... xxxiv

A Vestal Virgin ..............................iii

Evening...................................... xv

Puss.............................................vi

Near Point Judith......................xxxviii

The Broken Vase.........................xxiv

Richelieu and Julie .......................v

The Veiled Prophet. .........................iv

At Home....................................xxxi

Out-Door Luxury............................xii

Forenoon, Adirondacks....................ix 


\section{GENERAL INDEX.}

\section{INDEX TO ARTISTS.}

\section{(BY NUMBERS.)}

Achenbach, O., r73.

Aguilar, 4I4.

Alexander, H., 393.

Anders, E., 865.

Andrews, E. F., 26.

Aubinière, G. M. de l', $\sigma_{4}$

Audubon, J. J., II 5, r40.

Bacher, O. H., 37, r33, I88, 283.

Baker, W. B., I98, 369.

Barber, A., 48, 63, 282.

Barber, J. J., x9, 273, 336 .

Barber, T. S., 435, $44 \mathrm{I}$.

Baron, D., r67.

Beard, W. H., IrI.

Beaumont, C. F. E. de, 459 .

Beckel, M. J. C., 208.

Benney, S. F., 344,

Benson, Eug., 385 .

Berry, P. V., 384 .

Beul, F. de, $175,264$. Beul, F. de, $175,264$.
Bierstadt, A., 30, I8x, r85, De Hagueman, I83. 446.

Bisbing, H., 6r, 76, 9 r.

Blackman, W., ro4, 433 .

Böks, E. J. 25.

Holmer, M. de F., 205, 320.

Boyce L. F., 34, I50.

Boyd, Clarence, 228.

Botto, J. B., 424.

Bradford, W., 46, 268.

Brendt, Carl L., 3I I, 345.

Brenner, Carl C., 7I, I94, 207. 33I, 355, 405, 4I9.

Brenner, Charles, 90, 432.

Brevoort, J. R., I70, 250

Bricher, A. T., I93, 246.

Bridgman, F. A., $3^{\text {I } 8 . ~}$

Bristol, J. B., 8 .

Brownescombe, J., I I4.

Brooke, R. V., 7o.

Brown, J. G, I57, I76, 293, Ferguson, H. E., I45, 24 I. $332,425,456$.

Brown, W. M., 263, 274 .

Bruger, C. $50,53$.

Buhler, Zuler, I56.

Bunce, W. G., 4II.

Bunner, A. F., 225 .

Burnmeister, P., 36r, 368.

Burr, L. H., r89.

Burrell, J., 200.

Callcott, A. W., 58.

Caliga, J. H., I20.

Canova, A., VII.

Carl, August, 8.

Carte, A., 155 .

Casilear, J. W. , 2 216, 296. 408.

Champney,.J. W., 2 II. 362,363 .

Clark, G. M., 255.

Colman, S., IOO, IOI, 329

Coman, C. B., 36o, 461 .

Conant, C. W., 375 .

Contenieux, 4r3.

Corelli, A., зот.

Coroenne, H., 330.

Craig, $\mathrm{T}$. B , 3I7,

Crane, Bruce, 407 .

Cropsey, J. F., 394.

Daubigny, C. F., 450.

De Beaumont, C. F. E. 454 .

De Luce, Percival, r86.

Castagnola, Prof. G., 387, Gifford, R. Swain, 44 .

Gifford, Sanford R., 243, 27 .

Chase, Harry, 2r4, 239, 327, Gittard, A., 46o.

Gray, Sophie, 75, 77 .

Griswold, W., 33 .

Gude, Hans Fred, 453.

Guillaume, rg6.

Guy, Seymour J., r92, 234.

459. Hart, William, 29, 84, r78.

Haguemann, de, 183 .

Hahn, W, $26_{5}, 455$.

Hamilton, H., 300, 43 x.

Hammer, J. J., 277 .

Haquette, G., 347 .

Harnette, W. M., 313, 335.

Hart, James M., 22, 346 .

Hart, Joel T., I, II, V, VI,

De Haas, M. F. H., 83, r22, Hartwich, H., I31.

Healy, G. P. A., 8o.

Detroit Art I Art Loan Associa- Herpfer, Carl, 439

tion, I7r.

Dewey, C. M., 279.

Diego, 5 .

Dielman, F., 295.

Dietrich, E., I84. Hillern, B. von, I39.

447.

Doyle, John, 17.

Dyck, Anthony Van, 452.

Eaton, C. H., 258.

Eaton, C. W., 57, 180.

English, F. F.

Evans, De Scott, 123.

Farny, H. F., 24.

Fisher, T. J., 343 .

Fitch, J. L., 238.

Foote, E. K., 28.

Fuechsel, H., 20x, 342 .

Fuller, G F., 95, г36.

Fulton, Edward, IV.

Frazer, Olim, ro5.

Freer, F. W., 286.

Frère, Theo., 96 .

Gainsborough, T., 74 .

Gaul, Gilbert, 427 .

Gay, Edward, 233, 309, 429.

Geibel, C., 5 I.

Gessellchap, 6 .

Gibson, IV. H., I37.
Hetzel, George, 7, 59, 230, 303.

Hicks, Thomas, II.

Hill, Thomas, 262.

Hillern, B. von, I39.

Hopkin, R., $x_{3} .463$.

Hovenden, T., 370, 376 .

Hubbard, R. W., I35.

Iubner, J., $2 \times 3$.

Huntingdon, D., $42 \mathrm{r}$.

Inman, Henry, r29.

Inness, George, 212, 267.

Irwin, Benoni, 72, 79, \&9, 374 .

Johnson, Eastman, тзо.

Joiner, H., 6.

Jones, Annie W., 94.

Jones, H. Bolton, 256, 37r, 39 I.

Jouett, M. H., I27, 23I.

Kappes, A., I49.

Kelly, J., 8, 88.

Kensett, J. F., 457.

Kirby, Mattie'W., $8 \mathrm{r}$.

Kirkpatrick, F. L., 32 r.

Klumpke, A., 218, 430, 445 .

Koek-Koek, B. C., 357 .

Kollock, M., 378 . 
La Farge, John, I32.

Langheimer, 73 .

Lanman, C., I43.

Leisser, M., 378 .

Leslie, C. R., 16, 353 .

Lippincott, W. H., 275 .

Logarı, Jennie, 42, 422 .

Loop, H. A., 323.

Lyman, Jos., jr., 236, 245.

Macy, W. S., 240, 305, 434.

Maes, E. R., I65, 254.

Malecki, W., 398.

Manzuoli, after Raphael, I28.

Marechal, 356.

Marko, Andrea, 153, 197.

Marny, Paul, 443.

Marschall, Nicola, 349.

Martin, Homer, 390.

Mayer, Constant, I99, 248, $35^{8}, 397$.

McCord, G. H., 206, 38 r.

McEntee, J., 235.

McKinstry, G. A., 278, 400 .

McLeod, W., after Muller, 67.

Meadows, J. E., $4 \mathrm{r}$.

Miller, Chas. H., I9o, 259.

Miller, Francis, 204.

Millet, F. D., I7I.

Milton, Minnie, 219.

Moran, Edward, I 72, 404.

Moran, Leon, 86.

Moran, Percy, 23, 39, 326, 442.

Moran, Peter, 99, I59, 448.

Moran, Thomas, 47,107 .

Morgan, Annie, 302 .

Morgan, William, 103, 253 , 402.

Morrison, G. W., I58.

Mulvany, John, I2, $16_{3}$, I82, Smith, T. L., 55, 364, 417, 423.

Nehlig, Victor, 392.

Nicholls, B. H., т $6,386$.

Nicholls, R. H., 287 .

Nicoll, J. C., 252.

Oertel, Johannes A., 35, 334.

Parrish, Stephen, 237.

Parton, Arthur, I24.

Parton, Ernest, 21. 440.

Ream, Morston, 66, 202.

Ribes, G., 292.

Richards, T. A., 28I.

Rix, Julian, 348.

Robbins, H. W., 247.

Rosa, Salvator, 242.

Rosenboom, A., 97 .

Ryder, P. P., 227.

Salvator Rosa, 242.

Satterlee, Walter, 257.

Saul, G. H., III.

Schenck, A. F. A., 26r.

Schuchardt, F., jr., t62.

Schweninger, R., 3 Io.

Shackelford, I54.

Sharples, G., 333, 395.

Shurtleff, R. M., 314.

Silva, F. A., $3^{82}$.

Simons, H., I25.

Smedley, W. T., I42.

Smith, Eva B , I95. 373.

437.

Snyder, W. A., 306.

Sonntag, W. L., 87, 224.

Steen, Jan, 108.

Stevenson, H. S., 350.

Stewart, J. L., 34I.

Stites, J. R., 444 ,

Sully, Thomas, 20.
Perry, E. Wood, 92, 260, 351. Thaxter, E. R., IV.

Phelan, C. T., 223, 25I, 29I. Thom, J. C., 428.

Piotrowski, F. A., 383. Thum, Patty, 35, 121.

Platt, C. A., 38, I77, 249, 401. Tiffany, L. C., 221.

Portielje, J., 49, 52 . Tojetti, V., I10, 222,

Price, Gen. S. W., 4I5, 4I8. Tosta, Campo, $33^{8}$.

Toussaint, L., 187,399

Quartley, Arthur, I13, 269, Tracy, John M., I48, 389,

Rehn, F. K. M., 65, 226, 337 .

Rembrandt, Van Ryn, 304.

Richards, W. T., 31, 54, 340 .

Rousseau, Thèodore, 458 .

Ryn, Rembrandt Van, 304. Von Hillern, B., 139.

Sarony, N., I, 2, 3, 4, s5, 179 .

Shirlaw, Walter, 203, 209.

Smith, H. P., 280, 284, 366 ,

Smith, Xanthus, 102, 328.

Solimena, Francesco, irg.

Story, George H., I18, 1.4. Yewell, George H., 168.
Voorhes, G., 315.

Trego, W. T., 62, 98.

Turner, J. M. W., I8.

Ulrich, C. F., 312

Unknown, after F. Vinea, I26.

Van Boskerck, R. W., 225, 266, 272.

Van Dyck, Anthony, 452.

Van Ryn, Rembrandt, 304

Vernier, Emile, I46.

Wall, A. Bryan, 9, 56, 93.

Wall, William, 298.

Waller, Frank, 43, 169, 174.

Ward, Edgar M., I47, 4 IO.

Waugh, F. J., II 2 .

Weber, Carl, 276, $290,43^{6}$.

Weber, Edward, 164 .

Weber, Paul, I52, 462 .

Weber, Philip, 5 .

Weber, Theodore, 68.

Weyl, Max, 78, 220.

Whittredge. W.., 367,377

Wiggins, Carlton, 352 .

Wiles, Irving R, 359 .

Williams, E., 285 .

Wilmarth, L. E., I5r.

Wilson, - - 372 .

Wilson, R. B., 106, 438 .

Vindmere, J., 45I.

Witt, J. H., I34, 325.

Wood, J. Ogden, 409.

Wood, T. W., 449.

Woodwell, Jos. R., 27, 6o, I38, 297, 380, 4I2, 464 .

Wyant, A. H., Iog, 339 .

Zingoni, A., I66. 


\section{INDEX TO CONTRIBUTORS.}

\section{(BY NUMBERS.)}

Adams, Mrs. S. C., 8 o.

Allen, Major C. J. F., rog, I78, 354 .

American Art Association, $29,104,212,233,243,267$, $381,433$.

American Art Union, Io, II, 26, 30, 31, 32, 33, 36, $43,46,59,72,78,83,84$, $87,92,95,99,103,107$, III, II 7, I1 8, I22, I23, I24, I30, I33, I35, I36, I37, I4I, I4 4 , I44, I 45, I47, I48, I5I, I59, 160, I63, I68, 169, I70, I74, I8I, 185, I 86, I88, I89, I9o, I92, I94, I99, 201, 203, 205, 206, 209, 2IO, 2II, 2I6, 2I 7, $220226,227,234,235,236$, $237,238,239,24 \mathrm{I}, 246,247$, $248,250,252,253,256,257$, $259,260,262,263,268,273$, $274,281,283,286,288,294$, $295,296,300,306,309,3^{14}$, $3 \mathrm{I} 7,320,322,323,324,33 \mathrm{I}$, $33^{2}, 336,337,339,340,342$, $348,351,352,355,360,362$, $363,364,367,370,375,377$ $378,394,397,402,405,406$, $407,419,421,427,429,431$, $437,447,448,449,46 \mathrm{x}$.

Art Gallery of the Kentucky Polytechnic Society, II, III, VII, VIII.

Audubon, Miss H. B., II5, I 40

Baker, W. B., 369.

Barber, Alice, $48,63,282$.

Barber, J. Jay, I9,

Becker, Maria J.' C., 208.

Botto, J. B, , 424 .

Boyce, L. F., 34, I50.

Brandt, Carl L., 3II, 345 .

Brenner, Charles, 90, 432.

Brooke, R. V., 70 .

Brown, J. G., 456.

Brownscombe, Jennie, Ir4.

Carl, August, 8.

Carter, Thomas, 6 r.

Clarke, Thomas B., 326.

Cooper, J. T., 65.

Davis, William Henry, 85, 453.

D'Utassy, General, 184.

Earl, Harrison, 15 $_{5}$ 76, 9I, I 52, 276, 290, 299, 396, 425, 436,454 .
Earle, James S., \& Sons., $25,49,52,82, I_{02}, I_{12}, I_{5} 6$, I64, I96, 328, 403 .

Eaton, C. W., 57, I80,

English, F. F., I4.

Farrell, Col. John, 452.

Field, R. F.\& Co., 439,

Fink, Albert, 79 .

Fleischmann, C., I63.

Frankel, N. A., 69, 213, 365, 399.

Frazer, Miss Bessy, I05.

Gaertner, Philip, 3 Io.

Gillespie, J. J., \& Co., 7, 9, $27,56,60,93,138,230,297$, 298, 304, 344, 379, 380, 4I 2 , 464.

Grady \& McKeever, 55, I3I, I6I, I93, 245, 255, 277, $319,329,384,428$.

Hahn, William, 265, 455 .

Hart Memorial Assoc'n, I.

Hart, J.'M., 346.

Hegan Brothers, 200, 435, $44 \mathrm{I}$,

Hillern, B. von, I39.

Hirst, Claude R., 215.

Hopkin, R., I3.

Irwin, Benoni, 89, 374.

Janentzky, C., 50, 53, 462 .

Johnson, Mrs. C. F. 228, 254, 315.

Joiner, H., 6.

Jones, Annie W., 94.

Kentucky Polytechnic Society, Art Gallery of the, II, III, VII, VIII.

Kentucky, State of, V, VI.

Leaming, Dr. J. R., I6, I7, I8, 2I, 4I, 58, 74, I00, IOI, 108, 1 $26,242,292,353,357$, $4 \mathrm{I} 3,4 \mathrm{I} 4$.

Logan, Jennie, 42, 422,

Logan, Mrs. M. P., 244.

Marschall, Nicola, 349 .

M'Cready, L. A., 463.

M'Fadden, F. T., 28,

M'Kinstry, G. A., 278, 400 .

M'Leod, W., 67 .

Menefee, R. J., 24, 37, II9, $231,269,307,316,327,333$, $359,371,385,392,395$.

Milton, Minnie, 210.

Moore, George H., 7 I, I65, $^{2}$ I $75,176,187,207,270,280$, $285,289,32 \mathrm{I}, 335,338,358$, 404 .

Moran, Leon, 86.
Moran, Percy, 23, 39, 442.

Morgan, Annie, 302.

Morrison, G. W., 158 .

Nicholls, B. H., I $16,386$.

Nicholls, R. H., 287.

Platt, C. A., 38, I77, 249, 40 I.

Polytechnic Society of Kentucky, Art Gallery of the, II, III, VII, VIII.

Price, General S. W., 4I5, 4 I8.

Pullman, George M., 446.

Ream, Morston, 66, 96, 134 , 202, 225, 271, 272, 293, 325, $332,366,440,450,458$.

Reed, Mrs. J. M., 40, 127, I28, I53, I55, I66, I97, 232 , $308,387,408$.

Reichard \& Co., I9r, 229, 240, 26r, 347, 39r.

Robinson, J. M., 167 .

Sarony, N., I, 2, 3, 4, 44, 45, $64,88,172,179,221,318$, 434,443 .

Semple, William, 214, 224 460.

Smith, Eva B., 195.

Speed, Mrs. Joshua F., 372.

State of Kentucky, V, VI.

Stevenson, H. S., 350 .

Story, George H., I57.

Temple, Joseph E,, 20, 97, $264,301,459$.

Thomas, Major W. H., I2, I82, 343, 423 .

Tojetti, Vergilio, Ixo, 222, 426.

Trego, W. T., 62, 98.

Utassy, General De, 184 .

Van Boskerck, R. W., 266.

Viel, Ernest, I54.

Von Hillern, B., I39.

Vorce, A. D. \& Co., 54, 68, I73, 34r, 36r, $368,373,398$.

Wayne, Joseph W., 5, 5I, I46, 330, 383 .

Wildberger, R. H., 304.

Wilmurt, T. A., 22, 47, II3, 120, $1_{32}, 1_{42}, 1_{49}, 1_{98}, 204$, $223,25 \mathrm{I}, 258,275,279,284$, 29I, 305, 312, 31 $3,376,388$, 390, 393, 409, 4IO, 4II, 4I7, $420,444,457$.

Wiswell, W., jr., 218, 430,

Wooldridge, Mrs. P., 73, I25, I83, 389, 45I.

Young, Colonel B. H., 356 . 



A TALEN'T for any art is rare; but it is given to nearly every one to cultivate a taste for art,-only it must be cultivated with earnestness. The more things thou learnest to know and to enjoy, the more complete and full will be for thee the delight of living.

-Platen. 




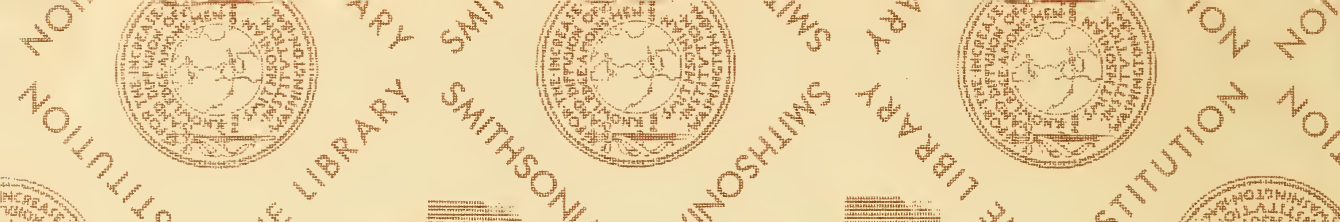

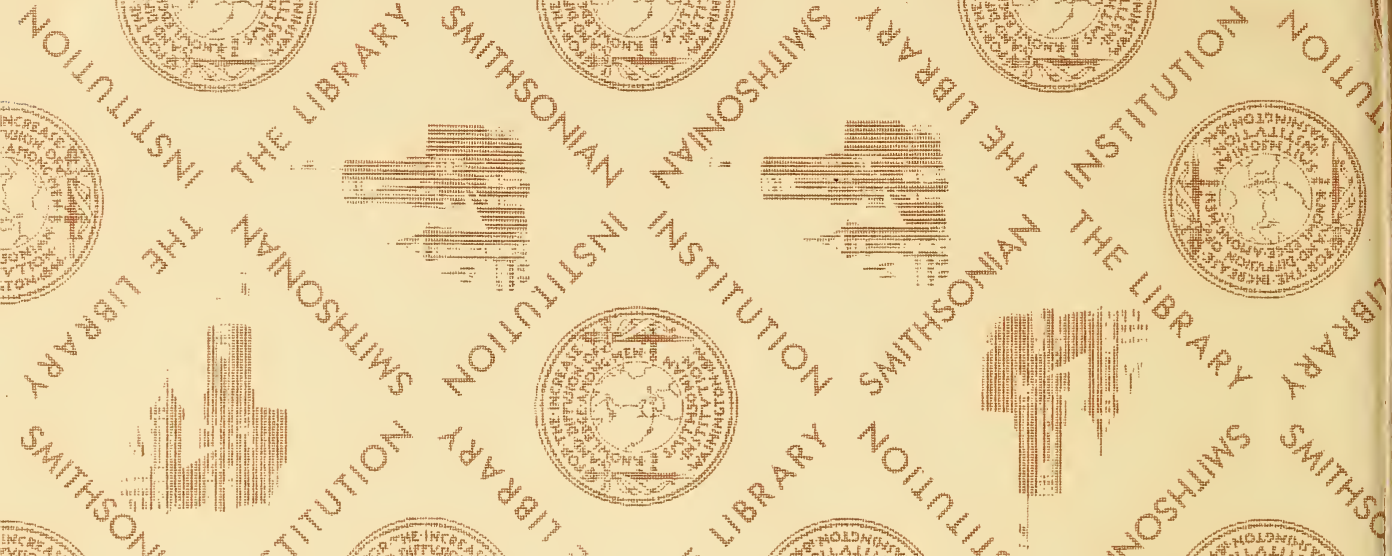

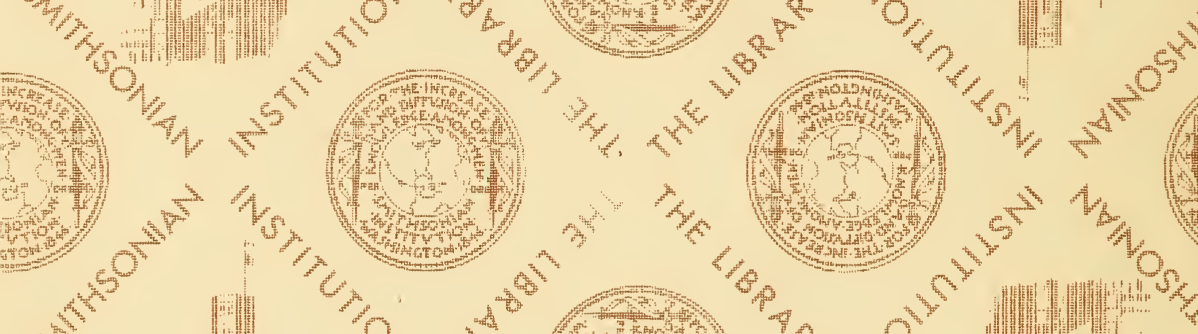

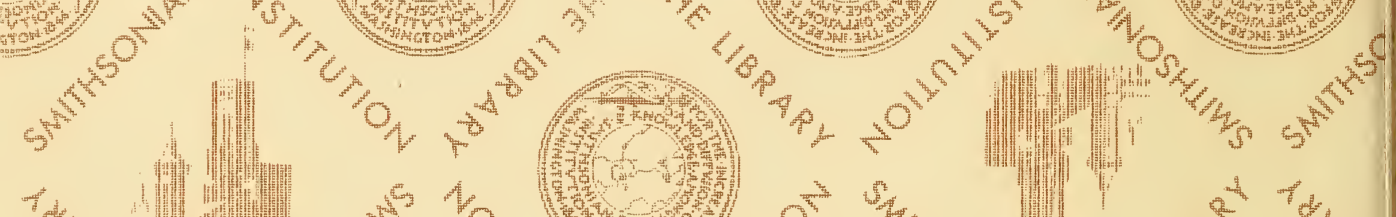

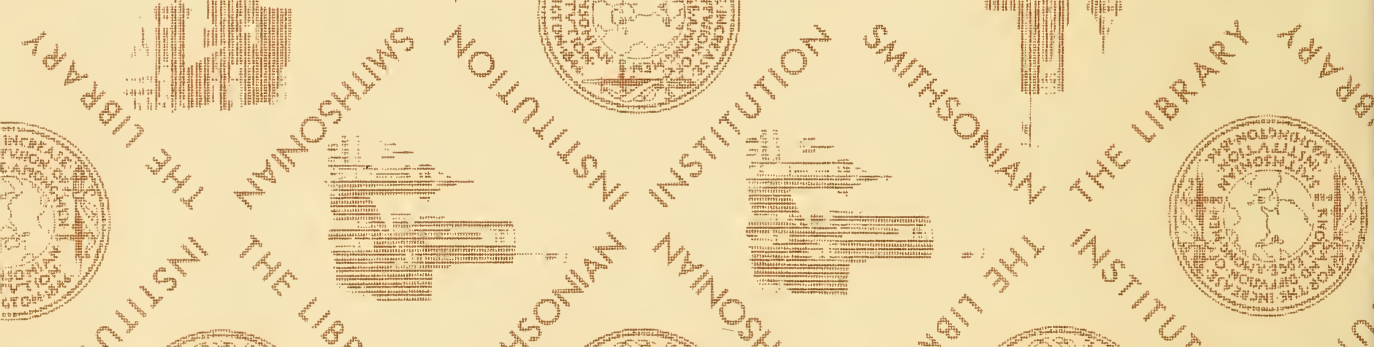

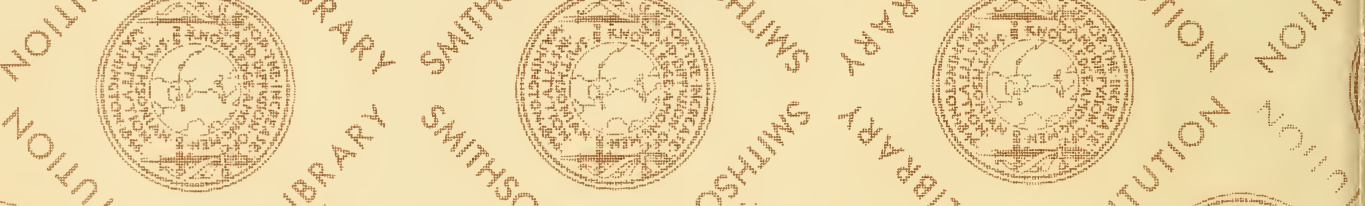

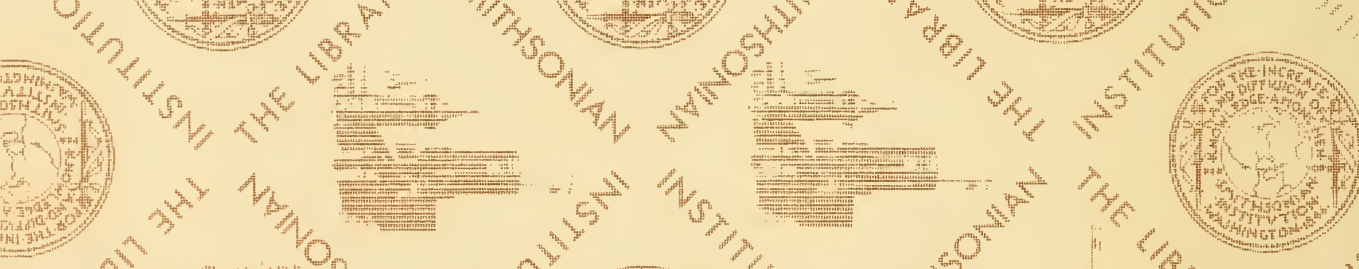

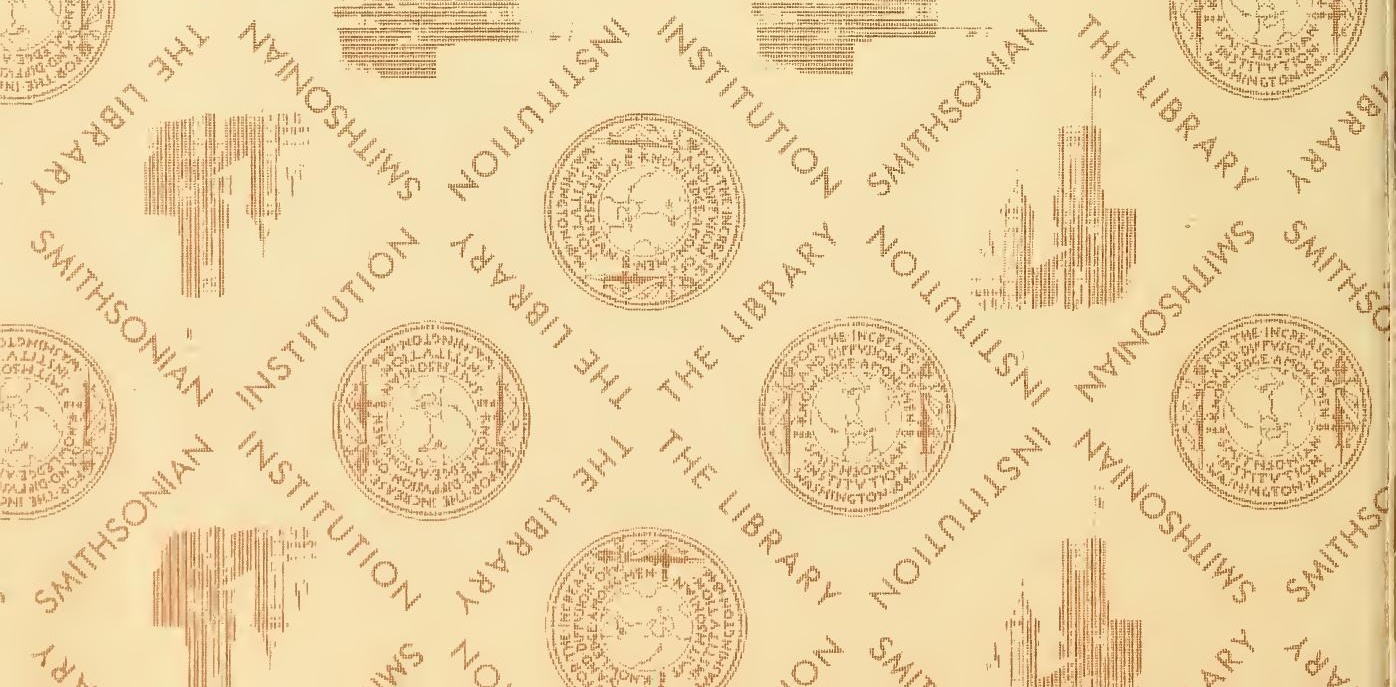



